\title{
Rhizopus oryzae Lipase, a Promising Industrial Enzyme: Biochemical Characteristics, Production and Biocatalytic Applications
}

\author{
Josu López-Fernández, Maria Dolors Benaiges (D) and Francisco Valero * (D) \\ Department of Chemical, Biological and Environmental Engineering, School of Engineering, \\ Universitat Autònoma de Barcelona, Bellaterra, 08193 Barcelona, Spain; josu.lopez@uab.cat (J.L.-F.); \\ mariadolors.benaiges@uab.cat (M.D.B.) \\ * Correspondence: Francisco.valero@uab.cat; Tel.: +34-93-581-1809
}

Received: 13 October 2020; Accepted: 30 October 2020; Published: 3 November 2020

check for updates

\begin{abstract}
Lipases are biocatalysts with a significant potential to enable a shift from current pollutant manufacturing processes to environmentally sustainable approaches. The main reason of this prospect is their catalytic versatility as they carry out several industrially relevant reactions as hydrolysis of fats in water/lipid interface and synthesis reactions in solvent-free or non-aqueous media such as transesterification, interesterification and esterification. Because of the outstanding traits of Rhizopus oryzae lipase (ROL), 1,3-specificity, high enantioselectivity and stability in organic media, its application in energy, food and pharmaceutical industrial sector has been widely studied. Significant advances have been made in the biochemical characterisation of ROL particularly in how its activity and stability are affected by the presence of its prosequence. In addition, native and heterologous production of ROL, the latter in cell factories like Escherichia coli, Saccharomyces cerevisiae and Komagataella phaffii (Pichia pastoris), have been thoroughly described. Therefore, in this review, we summarise the current knowledge about $R$. oryzae lipase (i) biochemical characteristics, (ii) production strategies and (iii) potential industrial applications.
\end{abstract}

Keywords: Rhizopus oryzae lipase; Pichia pastoris; biodiesel; structured lipids; flavour; ester; bioprocess engineering; operational strategy; racemic resolution

\section{Introduction}

Enzymes are highly efficient biocatalysts with several current and potential future applications in industrial-scale catalysis because of their widely researched advantages, such as their operation in milder conditions, outstanding selectivity and specificity and their lower environmental and physiological toxicity [1-4]. Likewise, social concerns and public policies are forcing industries to shift from manufacturing pollutant processes to more eco-friendly approaches in which biocatalysis can develop a significant role [5-9]. Consequently, the market for industrially relevant enzymes is expected to reach $\$ 7.0$ billion by 2023 from $\$ 5.5$ billion in 2018 at a remarkable compound annual growth rate (CAGR) of $4.9 \%$ for the period 2018-2023 [10].

Currently, hydrolytic enzymes dominate the market of industrial enzymes, accounting for more than $70 \%$ of all the sales [11]. Amongst them, lipases (triacylglycerol hydrolases E.C. 3.1.1.3) are the third largest group after proteases and amylases [12-14]. The main reason of their importance is based on the wide variety of industrially relevant reactions that they can carry out (Figure 1). In aqueous media, lipases catalyse the hydrolysis of fats at the water/lipid interface by cleaving the ester bonds with the concomitant consumption of water molecules and producing the corresponding fatty acids and glycerol or alcohol. Additionally, because of the principle of microreversibility, in non-aqueous 
media they might perform the reverse reaction, the so-called synthesis reactions. These reactions, in turn, can be classified as esterification, where a double displacement reaction between alcohols and carboxylic acids occurs resulting in esters and water; transesterification, where the acyl group of an ester switches with an alkyl group of an alcohol, acid or another ester resulting in alcoholysis, acidolysis and interesterification reactions respectively; and rarely, aminolysis, where carboxylic esters are converted to the corresponding carboxylic amides [15-20]. This vast versatility makes lipases suitable for several applications such as flavours, detergents, pharmaceuticals, bioenergy- and fine-chemicals-producing industries $[14,21]$.

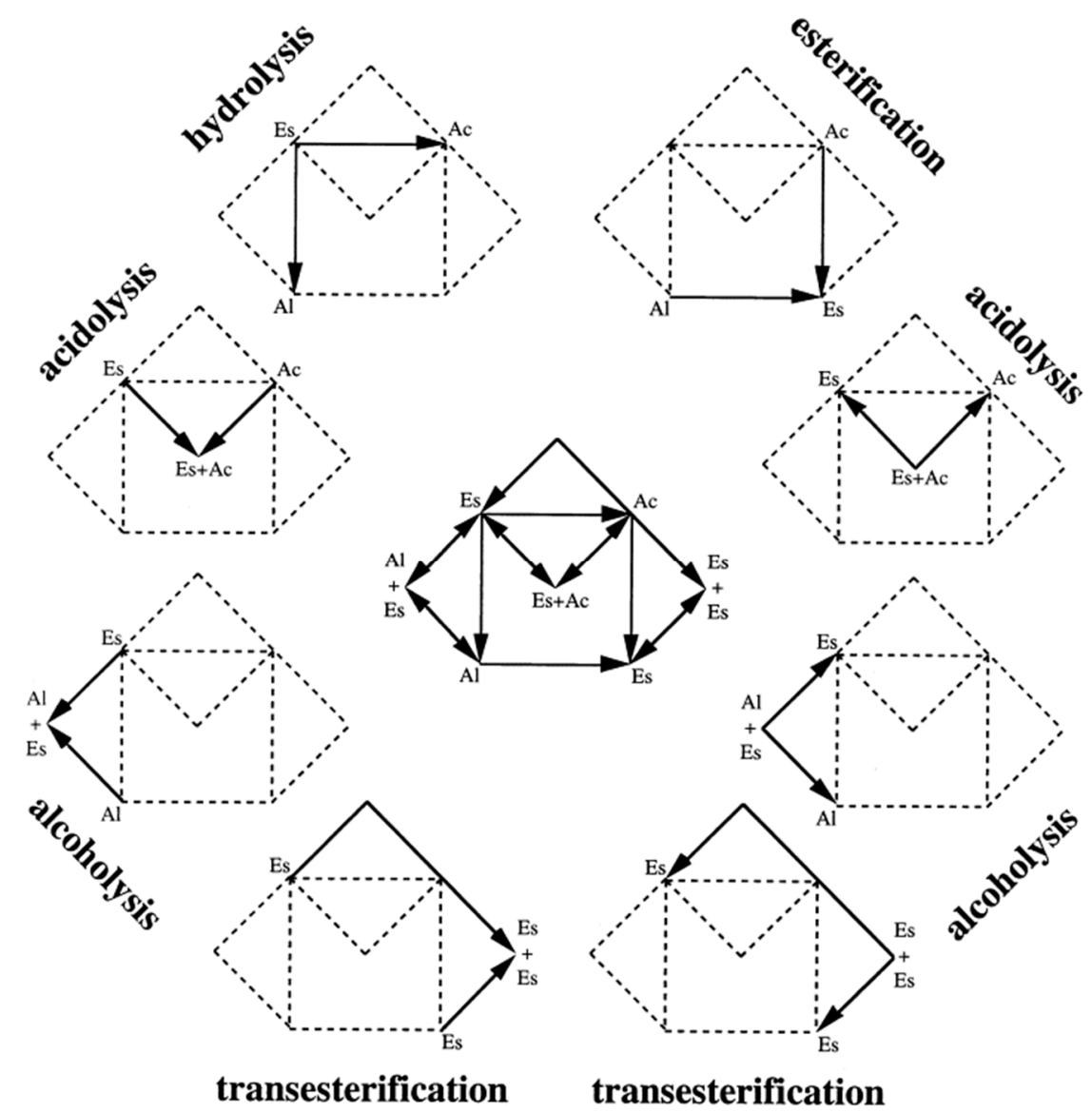

Figure 1. Wireframe of the lipase-catalysed reaction domain. Es, Al and Ac are the shortenings of esters, alcohols and acids respectively. Reactants are depicted before the beginning of arrows, products are depicted after the end of arrows, reproduced with permission from [19]. Copyright 2000, Elsevier.

Lipases can be fundamentally classified based on two traits (Figure 2), specificity and source [15,22]. The former includes three different subclasses; substrate specific lipases, which can selectively act on a specific substrate between a mixture of crude raw materials [23-26], enantioselective lipases which preferentially hydrolyse one of the isomers of a racemate over the other [27-30] and regioselective lipases which favour their activity depending on positional specificity and can be divided, in turn, in three classes [31-33]. Non-specific lipases catalyse the hydrolysis of triacylglycerols (TAGs) into free fatty acids and glycerol with mono- and di-glycerides as intermediates. These lipases can act over all the fatty acids from any position of the substrate. For instance, Candida antartica lipase is one of the most employed and studied non-specific lipase [34,35]. Fatty acid-specific lipases show fatty acid selectivity and they tend to hydrolyse esters containing long-chain fatty acids with double bonds in between C-9 and C-10. Some examples of these enzymes are lipases from Geotrichum candidum [36] and Penicillium citrinum [37]. 1,3-specific lipases, such as Rhizopus oryzae [38,39] and Yarrowia lipolytica lipases [40], hydrolyse the acylglycerols present in positions $s n-1$ and $s n-3$ of the TAG producing 
free fatty acids, 2-monoacylglycerols and 1,2- or 2,3-diacylglycerols, avoiding the final production of glycerol. During this reaction, formation of diacylglycerols has been reported to occur faster than monoacylglycerols formation [33]. Moreover, with 1,3-specific lipases, acyl migration phenomena might take place, which is a non-enzymatic process that involves spontaneous movement of an acyl group from one hydroxyl group to an adjacent one. Thus, the formed product after the hydrolysis with 1,3-specific lipases might suffer acyl migration yielding 1,3-diacylglycerols and 1-monoacylglycerols from 1,2- or 2,3-diacylglycerols and 2-monoacylglycerols, respectively. In addition, glycerol might be obtained as the final product after extended reaction times [32].

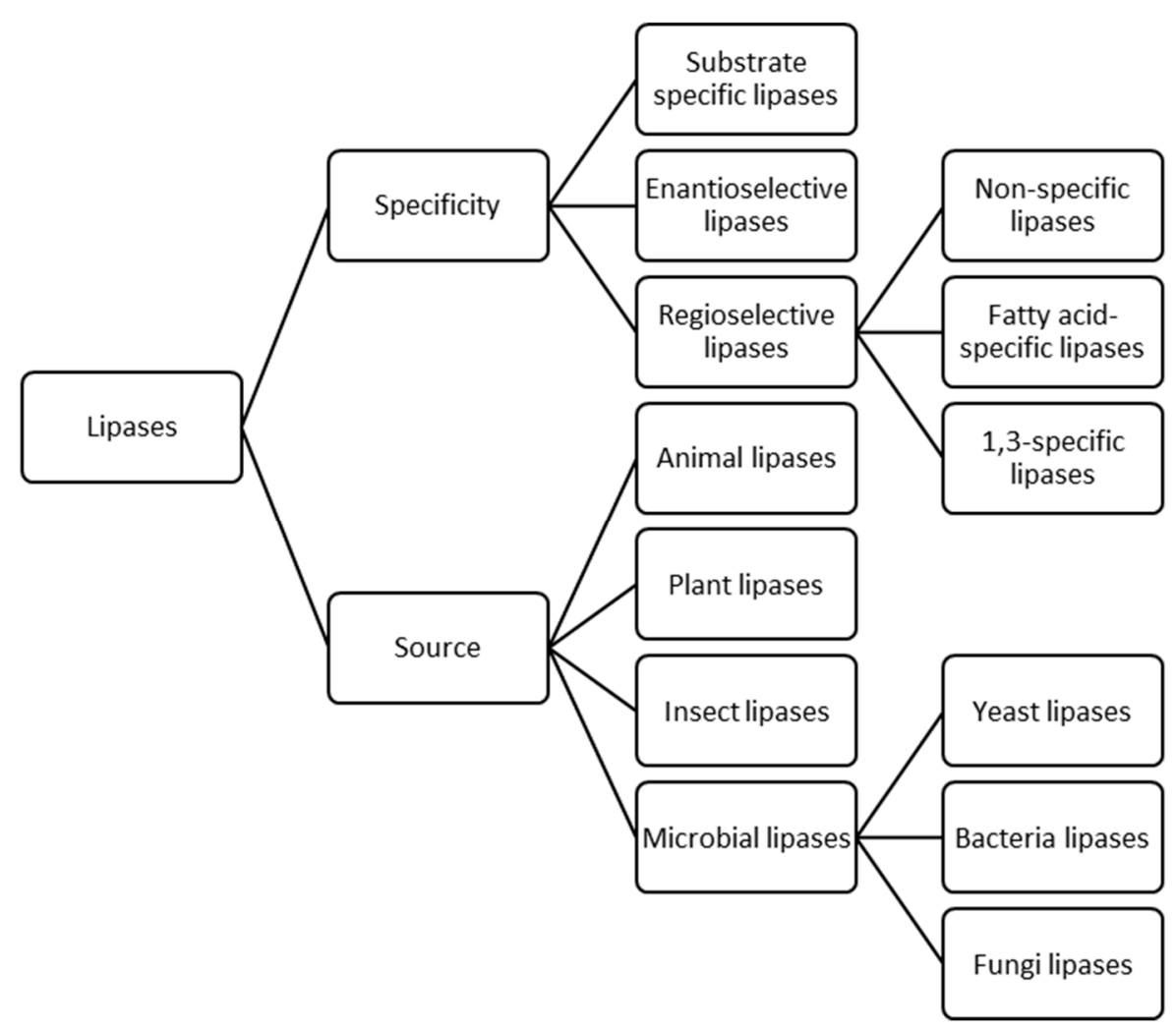

Figure 2. Classification of lipases based on their specificity and source.

In terms of lipases source, they can be classified as animals, plants, insects and microbial lipases which includes yeasts, bacteria and fungi lipases [15,41]. Microbial lipases have been described to have some desirable traits in comparison to animals and plants lipases, for instance: higher stability, chemo-selectivity, enantio-selectivity and the absence of cofactor requirements [16,22,31,42,43]. Concretely, fungal lipases have been broadly studied because of the known potential of native microorganisms to produce these enzymes and their notable unique catalytic properties. At industrial scale, most employed lipase-producing fungi belong to the genera of Rhizopus sp., Aspergillus sp., Penicillium sp., Geotrichum sp. and Mucor sp. [22,44,45].

Focusing on Rhizopus genus, owing to its industrial relevance, some attempts have been carried out in order to classify the species forming it and to reflect the key differences between them. However, the classification has changed over time and might have had a negative effect on lipase notation accuracy. Traditionally, the species have been differentiated based on morphological and physiological features [46]. For instance, Schipper [47] described the existence of three groups- $R$. microsporus, R. stolonifer and R. arrhizus (=oryzae). Lately, Abe et al. [48] carried out the first molecular phylogenetic study and concurred with the classification performed by Schipper. Subsequent studies differed from that classification and organised the genus into 10 [49] and 8 [50] species until Abe et al. [51] finally confirmed the 8 species division by using rDNA ITS, actin- 1 and translation elongation factor $1 \alpha$ 
$(E F-1 \alpha)$ sequences as differential traits. Notwithstanding these classifications, currently, most of the Rhizopus samples in culture collections belong to four species or species complexes: R. microsporus, R. stolonifer, R. arrhizus (or R. oryzae) and R. delemar (or R. arrhizus var. delemar) [46]. Amongst them, according to GenBank records, $R$. oryzae or arrhizus (including $R$. arrhizus var. delemar) is the most significant one as more than 7000 identified isolates have been reported [46].

$R$. oryzae is broadly employed in industry because it can carry out the synthesis of a great variety of products like organic acids (lactic and fumaric acids), volatile compounds and enzymes (cellulases, proteases, tannases, xylanasas, pyruvate decarboxylases, lipases etc.) [52-55]. Concretely, according to Web of Knowledge data, R. oryzae lipase (ROL) is one of the most studied enzymes of this fungi. There are three major commercial formulations of this lipase (Table 1) and more than 200 scientific works have been published in the last 5 years highlighting the relevance of this enzyme. Therefore, the aim of this review is to provide a complete overview of ROL in terms of biochemical properties, enzyme native and heterologous production and its industrial applications.

Table 1. Major commercial suppliers of Rhizopus oryzae lipase and some lipase properties [16].

\begin{tabular}{cccc}
\hline Supplier & Name & Application & Lipase Properties \\
\hline Amano & Lipase DF “Amano" 15 & Oil and fats & $\begin{array}{c}\text { Optimum pH range 6-7; stable } \mathrm{pH} \\
\text { range 4-7, optimum temperature } \\
\text { range 35-40 }{ }^{\circ} \mathrm{C} \text {, relatively specific } \\
\text { to fatty acids }\end{array}$ \\
\hline Sigma & Lipase from R. oryzae (no. 62305) & Oil and fats & $\begin{array}{c}\text { Optimum pH } 8, \\
\text { optimum temperature } 40^{\circ} \mathrm{C}\end{array}$ \\
\hline Sigma & $\begin{array}{c}\text { Lipase, immobilised on } \\
\text { Immobead } 150 \text { from } \text { R. oryzae } \\
\text { (no. 89445) }\end{array}$ & Pharmaceutical and bioenergy & $\begin{array}{c}\text { Optimum } \mathrm{pH} 7.5, \\
\text { optimum temperature } 40{ }^{\circ} \mathrm{C}\end{array}$ \\
\hline
\end{tabular}

\section{Biochemical Properties}

R. oryzae lipase (ROL) is a protein synthesised as a precursor form containing a presequence of 26 amino acids, followed by a prosequence of 97 attached to the N-terminal of a 269 amino acids mature sequence (Figure 3) [56]. All known lipases from Rhizopus genus follow the same identical structure even though some amino acidic substitutions can be detected when their primary sequences are compared, not only between different species but also between different isolated strains of the same species (Figure 4). For instance, Ben Salah et al. [57] addressed the presence of several substitutions in the sequences of Rhizopus lipases published by his group and Sayari et al. [58], Beer et al. [56], Derewenda et al. [59] and Khono et al. [60].

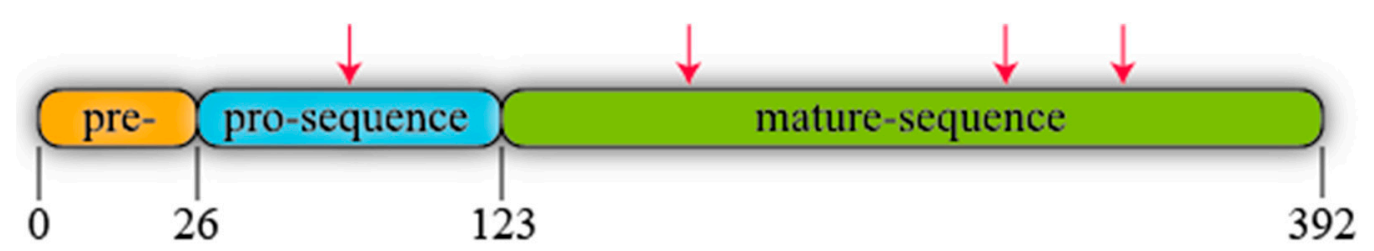

Figure 3. Schematic representation of R. oryzae lipase (ROL). Arrows stand for potential N-glycosylation points. 


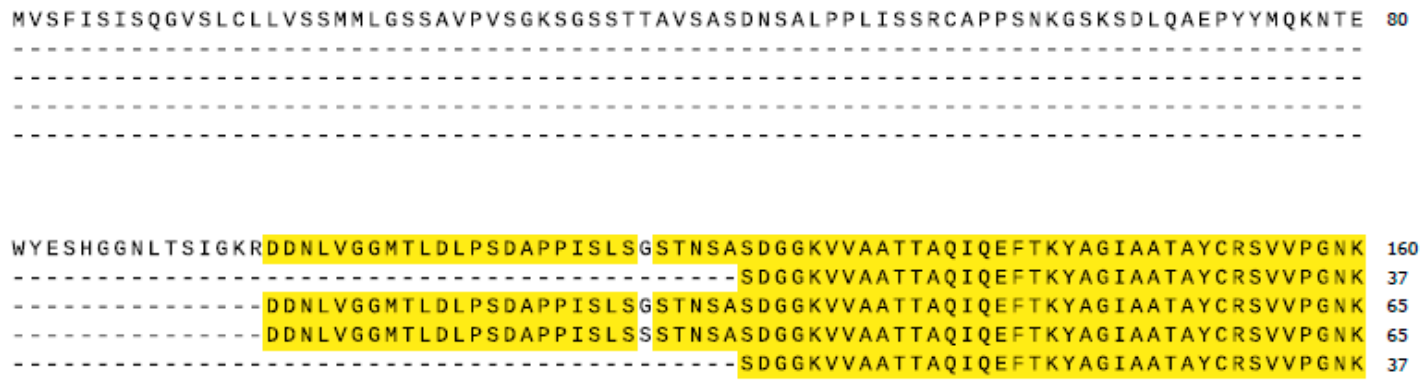

WDCVQCQKWVPDGKIITTFTSLLSDTNGYVLRSDKQKTIYLVFRGTNSFRSAITDIVFNFSDYKPVKGAKVHAGFLSSYE 240 WDCVQCQKWVPDGKIITTFTSLLSDTNGYVLRSDKQKTIYLVFRGTNSFRSAITDIVFNFSDYKPVKGAKVHAGFLSSYE 117 WDCVQCQKWVPDGKIITTFTSLLSDTNGYVLRSDKQKTIYLVFRGTNSFRSAITDIVFNFSDYKPVKGAKVHAGFLSSYE 145 WDCVQCQKWVPDGKIITTFTSLLSDTNGYVLRSDKQKTIYLVFRGTNSFRSAITDIVFNFSDYKPVKGAKVHAGFLSSYE 145 WDCVQCQKWVPDGKIITTFTSLLSDTNGYVLRSDKQKTIYLVFRGTNSFRSAITDIVFNFSDYKPVKGAKVHAGFLSSYE 117

\begin{abstract}
QVVNDYFPVVQEQLTANPTYKVIVTGHSLGGAQALLAGMDLYQREPRLSPKNLSIFTVGGPRVGNTFAYYVESTGIPFQ 320 QVVNDYFPVVQEQLTANPTYKVIVTGHSLGGAQALLAGMDLYQREPRLSPKNLSIFTVGGPRVGNTFAYYVESTGIPFQ 197 QVVNDYFPVVQEQLTAHPTYKVIVTGHSLGGAQALLAGMDLYQREPRLSPKNLSIFTVGGPRVGNPTFAYYVESTGIPFQ 225 QVVNDYFPVVQEQLTAHPTYKVIVTGHSLGGAQALLAGMDLYQREPRLSPKNLSIFTVGGPRVGNTFAYYVESTGIPFQ 225 QVVNDYFPVVQEQLTAHPTYKVIVTGHSLGGAQALLAGMLYQREPRLSPKNLSIFTVGGPRVGPTFAYYVESTGIPFQ 197
\end{abstract}

\begin{abstract}
RTVHKRDIVPHVPPQSFGFLHPGVESWIKSGTSNVQICTSEIETKDCSNSIVPFTSLLDHLSYFDINEGSCL 392 RTAHKRDIVPHVPPQSFGFLHPGVESWIKSGTSNVQICTSEIETKDCSNSIVPFTSILDHLSYFDINEGSCL 269 RTVHKRDIVPHVPPQSFGFLHPGVESWIKSGTSNVQICTSEIETKDCSNSIVPFTSILDHLSYFDINEGSCL 297 RTVHKRDIVPHVPPQSFGFLHPGVESWMKSGTSNVQICTSEIETKDCSNSIVPFTSILDHLSYFDINEGSCL 297 RTVHKRDIVPHVPPQSFGFLHPGVESWIKSGTSNVQICTSEIETKDCSNSIVPFTSILDHLSYFDINEGSCL 269
\end{abstract}

Figure 4. Multiple alignment of the sequences published by (1) Beer et al. (ROL) [56], (2) Ben Salah et al. (ROL) [57], (3) Sayari et al. (ROL) [58], (4) Khono et al. (Rhizopus niveus lipase) [60] and (5) Derewenda et al. (Rhizopus delemar lipase) [59]. Matching amino acids are highlighted in yellow, mismatching in white. BLAST from U.S. National Library of Medicine and Snapgene have been used for the creation of this figure.

ROL contains four potential N-glycosylations sites (Figure 3) that follow the consensus sequence Asn-X-Ser/Thr, where $X$ is any amino acid instead of proline. One of these putative sites is found in the prosequence where modifications in glycosylation patterns have been described to have an effect on protein secretion [61]. For instance, Yu et al. [62] added two extra N-glycosylation sites to ROL prosequence and expressed this mutant in Komagataella phaffii (Pichia pastoris). The extracellular activity and total protein were 218- and 6.25-fold higher respectively in the strain harbouring the two extra $\mathrm{N}$-glycosylation sites than in the non-modified one highlighting the relevance of glycosylation.

The presequence of ROL has been described to act as signal peptide promoting enzyme secretion, while the prosequence has been reported to exhibit diverse functions that are still under research. Beer et al. [63] depicted the significance of the latter in lowering lipase toxicity during its synthesis and in acting as intramolecular chaperone enabling the proper folding of the enzyme. In fact, genetically modified E. coli strains producing heterologous ROL without the prosequence resulted in cell lysis. To date, a large number of prosequences of different enzymes have also been identified to function as intramolecular chaperone and to assist the folding of their respective proteins [64]. In addition, several scientific works have related ROL prosequence with the translocation of the protein across the endoplasmic reticulum membrane, enhancement of free lipase stability and changes in enzyme substrate specificity. Nevertheless, the mechanisms that allow these traits are yet unknown despite the broad research carried out [65-70]. In any case, both the presequence and the prosequence are expected to be proteolytically removed to form the mature lipase. In spite of this, the native microorganism secretes a lipase that is attached to the $\mathrm{N}$-terminal of mature sequence the $28 \mathrm{C}$-terminal amino acids of the prosequence (proROL), which then are cleaved via limited proteolysis catalysed by 
extracellular proteases $[56,60,71]$. However, some studies have indicated that the presence of these 28 amino acids of the prosequence alongside the mature sequence is enough for some of the presumed features of the prosequence to occur. For instance, higher free lipase stability and changes in enzyme specificity have been described when the 28 amino acids of the prosequence were expressed together with the mature sequence in K. phaffii [39]. In addition, these amino acids have also enabled lowering the toxicity of ROL production in E. coli [63] and they have been related to direct proteins to secretory pathway in Aspergillus oryzae [72].

The mature sequence of $R$. oryzae lipase (rROL) is constituted by 269 amino acids and the protein formed by them has a molecular weight (MW) of $29.542 \mathrm{kDa}$ and a isoelectric point (pI) of 8-calculated by Expasy Proteomics Server [57]. These results agree with the published experimental data (Table 2) in which MW and pI values around $29 \mathrm{kDa}$ and 8 have been respectively reported $[58,60,73,74]$. However, variations in these values can be found because of the presence of the 28 amino acids of the prosequence described above $[39,60,70,75,76]$. In this case, MW increases to $32 \mathrm{kDa}$ and $\mathrm{pI}$ decreases roughly to 7, highlighting the average acid nature of these 28 amino acids. Besides, the production of a lipase including the whole prosequence and close to $40 \mathrm{kDa}$ has also been described (entire-proROL) [56,65].

The 3D structure of the lipase from R. oryzae [59,60] (Figure 5) and several microorganisms more, such as Geotrichum candidum [77], Candida rugosa [78], Pseudomonas glumae [79] and Penicillium camemberti [80] have been crystallographically resolved and showed that all lipases have a common $\alpha / \beta$ hydrolase fold structure that can also be found in other hydrolases [45]. Regarding ROL, it contains nine $\alpha$-helixes and eight $\beta$-strands forming a molecule that it is stabilised by three disulfide bonds between residues 29-269, 40-43 and 235-244 [60]. In addition, this structure contains three key components that can be also found in most lipases besides ROL, the lid, the active site and the oxyanion hole [15]. The lid is an amphiphilic loop-also called flap-that covers the active site preventing the access of the substrate while the enzyme is in aqueous medium [81]. The active site, in turn, is mainly responsible for carrying out enzyme catalysis and consists, in all $\alpha / \beta$ hydrolases, of a highly conserved catalytic triad formed by a nucleophilic, a catalytic acidic and a histidine residues. In lipases, this triad is composed of nucleophilic serine residue and an aspartic or glutamic acid residue that it is bonded to a histidine; hence, lipases are classified as serine hydrolases. In the specific case of ROL, the lid domain is a short $\alpha$-helix structure formed by six amino acids (FRSAIT) and the active site is formed by three amino acids Ser ${ }^{145}$, Asp ${ }^{204}$ and $\mathrm{His}^{257}[59,60,82,83]$. The function of these two elements is crucial during catalysis in which the lipase binds to the water/lipid interface and the lid opening occurs by a concomitant structural change in the substrate-binding site that enables the coupling of the substrate to the active site-lid-closed and partially opened 3D structures of Rhizopus delemar (=oryzae) lipase have been described by Derewenda et al. [59]. The structural change undergone is known as 'interfacial activation' and it is a unique property of lipases that enables them to hydrolyse insoluble esters and to distinguish them from esterases that can hydrolyse water-soluble esters [15,84-86]. It must be highlighted that the 28 amino acids of the prosequence introduced above have been deemed to interfere in this process as they are located next to the lid region and contain $50 \%$ hydrophobic residues. Therefore, this sequence extends the hydrophobic patch created in the open lipase by the open lid and the catalytic crevice influencing the interaction with the lipidic substrate [58]. This role might explain some of the assumed properties of these 28 amino acids, however, the mechanism remains unknown. Additionally, together with the catalytic triad and the lid, the oxyanion hole plays an important role and it is also a highly conserved sequence that largely influences the catalytic efficiency of the enzyme. During the hydrolysis reaction, a negatively charged tetrahedral intermediate is generated and it gets stabilised by hydrogen binding with the oxyanion hole $[15,87,88]$. This function has been described to be presumably performed by the hydroxyl and main-chain amide groups of $\operatorname{Thr}^{83}$ in ROL $[59,60,89]$. 

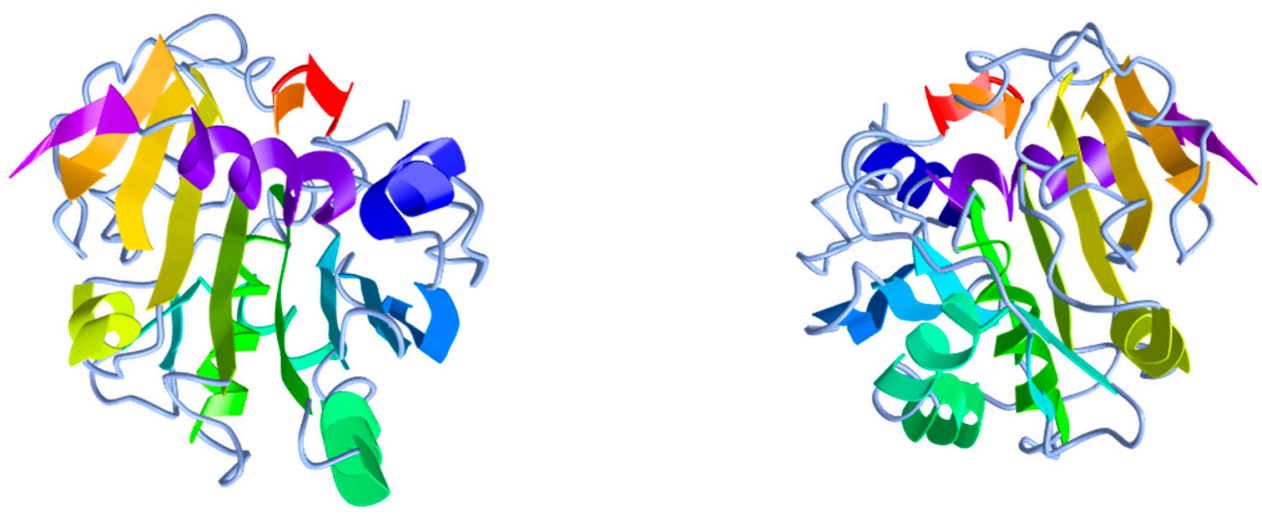

Figure 5. Three-dimensional structure of $R$. delemar (= oryzae) lipase from two different points of view. PDB ID: 1TIC. Image obtained from iCn3D web-based 3D structure viewer.

Because of the relevance of the lipolytic activity of this enzyme, it has been widely researched in order to know how it is affected by the conditions of reaction medium. Guillen et al. [90] described that ionic strength has a remarkable impact. Actually, the relative activity of ROL in $200 \mathrm{mM}$ Tris- $\mathrm{HCl}$ was reported to be twice the activity observed in $400 \mathrm{mM}$. Moreover, as all enzymes, ROL activity is highly influenced by the $\mathrm{pH}$ and temperature. Optimum activity $\mathrm{pH}$ values of 8 have been principally reported $[56,57,73,75,90-96]$. However, other studies have also stated more acid [74,97-103] and basic $[68,104,105]$ optimums. Regarding temperature, most of the published optimum values can be found between 30 and $45{ }^{\circ} \mathrm{C}$. In fact, $40{ }^{\circ} \mathrm{C}$ has been the most commonly reported optimum [39,60,68,90,92,95,97,98,103,104] although lower [57,60,74,75,90,93,94,100,101] and higher [99,102] values have also been described (Table 2). Nevertheless, for both $\mathrm{pH}$ and temperature, as can be observed in Table 2, some of the differences are based on the presence of the 28 amino acids of the prosequence. In this line, Kohno et al. [60] reported these differences and afterwards, other works $[39,63,90]$ described similar results highlighting the relevance of these amino acids in lipase catalytic performance. 
Table 2. Biochemical properties and substrate specificity of different published works dealing with ROL.

\begin{tabular}{|c|c|c|c|c|c|c|}
\hline Lipase Name $^{1}$ & MW (kDa) & Isoelectric Point & pH Optimum & T Optimum $\left({ }^{\circ} \mathrm{C}\right)$ & Substrate Specificity & Ref. \\
\hline rROL & 29 & & $8 / 7.25^{2}$ & $30 / 40^{2}$ & $\mathrm{C} 12>\mathrm{C} 10>\mathrm{C} 8>\mathrm{C} 4^{4}$ & [39] \\
\hline proROL & 32 & & 7.25 & 40 & $\mathrm{C} 8>\mathrm{C} 12>\mathrm{C} 10>\mathrm{C}_{4} 4$ & [39] \\
\hline rROL & 30 & & 8.5 & & & [56] \\
\hline entire-proROL & 40 & & 8 & & & [56] \\
\hline pre-entire-proROL ${ }^{3}$ & 42 & & 8 & & & [56] \\
\hline rROL & 29 & & 8 & 37 & & [57] \\
\hline rROL & 29 & & & & & [58] \\
\hline proROL & 32 & & & & & [58] \\
\hline proROL & 34 & & $6-6.5$ & 35 & & [60] \\
\hline rROL & 30 & & 6 & 40 & & [60] \\
\hline proROL & 35 & & 9 & 40 & $\begin{array}{l}\mathrm{C} 16>\mathrm{C} 18>\mathrm{C} 12>\mathrm{C} 8>\mathrm{C} 4^{5} \\
\mathrm{C} 16>\mathrm{C} 12>\mathrm{C} 8>\mathrm{C} 18>\mathrm{C} 4^{6}\end{array}$ & [68] \\
\hline proROL & 32 & 6.9 & & & & [70] \\
\hline rROL & 30 & 9.3 & 8.25 & 30 & $\mathrm{C} 8>\mathrm{C} 10>\mathrm{C} 6>\mathrm{C} 4>\mathrm{C} 12>\mathrm{C} 16, \mathrm{C} 14>\mathrm{C} 2^{6}$ & [73] \\
\hline proROL & 35 & & 5.2 & 30 & $\mathrm{C} 12>\mathrm{C} 10>\mathrm{C} 8>\mathrm{C} 6>\mathrm{C} 16>\mathrm{C} 5>\mathrm{C} 4>\mathrm{C} 3>\mathrm{C} 22^{4}$ & [74] \\
\hline proROL & 32 & 7.6 & 7.5 & 35 & $\mathrm{C} 8>\mathrm{C} 6>\mathrm{C} 4>\mathrm{C} 2^{6}$ & [75] \\
\hline rROL & 29 & & & & $\begin{array}{c}\mathrm{C} 12>\mathrm{C} 10>\mathrm{C} 8>\mathrm{C} 6>\mathrm{C} 4>\mathrm{C} 3>\mathrm{C} 2^{4} \\
\mathrm{C} 8>\mathrm{C} 10>\mathrm{C} 18>\mathrm{C} 4>\mathrm{C} 6^{6}\end{array}$ & [90] \\
\hline proROL & 34 & & & & $\begin{array}{c}\mathrm{C} 2>\mathrm{C} 3>\mathrm{C} 8>\mathrm{C} 6>\mathrm{C} 12>\mathrm{C} 10>\mathrm{C} 4^{4} \\
\mathrm{C} 8>\mathrm{C} 10>\mathrm{C} 4>\mathrm{C} 6>\mathrm{C} 18^{6}\end{array}$ & [90] \\
\hline proROL & & & 8 & 40 & & [92] \\
\hline rROL & 30.3 & 8.6 & $8-8.5$ & 30 & & [93] \\
\hline proROL & & & 8.5 & 30 & & [94] \\
\hline proROL & 37 & & 8.5 & 40 & & [95] \\
\hline rROL & 29 & & 8 & & & [96] \\
\hline ROL & 17 & 4.2 & 7 & 40 & & [97] \\
\hline ROL & & & 7 & 40 & & [98] \\
\hline ROL & & & 6 & 45 & $\begin{array}{c}\mathrm{C} 8>\mathrm{C} 4>\mathrm{C} 6>\mathrm{C} 22^{6} \\
\mathrm{C} 8>\mathrm{C} 12>\mathrm{C} 14>\mathrm{C} 16>\mathrm{C} 18^{5}\end{array}$ & [99] \\
\hline proROL & 32 & & 7 & 35 & & {$[100$} \\
\hline ROL & & & 6 & 30 & $\mathrm{C} 7, \mathrm{C} 8, \mathrm{C} 12, \mathrm{C} 16>\mathrm{C} 2, \mathrm{C} 3, \mathrm{C} 4, \mathrm{C} 18^{5}$ & {$[101]$} \\
\hline ROL & & & 7.5 & 50 & & {$[102$} \\
\hline proROL & 32 & & 7.5 & $30-40$ & & {$[103$} \\
\hline \multirow[t]{2}{*}{ ROL } & 14.45 & 6.5 & 9 & $30-40$ & $\mathrm{C} 16>\mathrm{C} 18>\mathrm{C} 12>\mathrm{C} 8>\mathrm{C} 4>\mathrm{C} 2{ }^{4}$ & {$[104$} \\
\hline & & & 8.3 & $35-37$ & & {$[105$} \\
\hline proROL & 35 & & & & $\mathrm{C} 10>\mathrm{C} 14>\mathrm{C} 12>\mathrm{C} 8>\mathrm{C} 6>\mathrm{C} 4>\mathrm{C}_{16}{ }^{6}$ & [65] \\
\hline entire-proROL & 46 & & & & & [65] \\
\hline
\end{tabular}

${ }^{1}$ Names are based on the established nomenclature in this review. ROL indicates that the lipase cannot be classified under the determined parameters in this work; ${ }^{2}$ different values caused by the employment of 200 or $400 \mathrm{mM}$ tris-HCl buffer; ${ }^{3}$ pre-entire-proROL includes the presequence as well as entire-proROL; ${ }^{4} p$-nitrophenol esters were employed for substrate specificity analysis; ${ }^{5}$ methyl esters of different carbon chain length were employed for substrate specificity analysis. Saturated methyl esters are just considered; ${ }^{6}$ homotriacylglycerols were employed for substrate specificity analysis. 
The presence of metal ions in reaction medium has been extensively studied as they play different and important roles influencing the structure and activity of enzymes. These ions may bind to some of the amino acid side chains of the lipase and participate in catalysis, interfere with the bonds between amino acid side chains and cause denaturation of the active site or alter enzyme activity by stabilising or destabilising enzyme conformation [100,106-108]. Amongst the different published works some contradictory information can be found. Nevertheless, there are some metal ions that have been clearly described to enhance or worsen ROL and other lipases performance. Wang et al. [68] and other authors $[97,100,104]$ found that $\mathrm{Ca}^{2+}$ increases ROL activity as it might create electrostatic interactions that mask the repulsions either between the enzyme and its emulsified substrate or between the enzyme and product-free fatty acids [93]. On the other hand, $\mathrm{Hg}^{2+}$ has been reported to act like a ROL activity inhibitor suggesting that thiol groups are required for the adequate function of the enzyme [74]. Similar results have been reported with other lipases from Pseudomonas aeruginosa AAU2 [109], Galactomyces geotrichum Y05 [110], Yarrowia lipolytica [111] and Candida rugosa [112]. In addition, no significant effects have been observed with the chelating agent EDTA, indicating that ROL activity is independent of any metal, hence, it is not a metalloprotein $[74,104]$.

ROL activity has also been analysed in presence of amino-acid-modifying agents in order to elucidate the relevance of the different amino acids in protein catalytic performance. $\mathrm{N}$-Bromosuccinimide (NBS), which acts over tryptophan residues, have been reported to strongly inhibit enzyme activity indicating that the protein might have a tryptophan residue involved in its activity $[74,97]$. In the case of phenylmethylsulfonyl fluoride (PMSF), a serine protease inhibitor whose activity is related to serine residues modification, no clear results have been reported. Kantak et al. [97] indicated that this agent has a relevant effect while Hiol et al. [75] stated exactly the opposite. However, these differences might be caused by the different disposition of the lipase lid during the assay, that is, if it was open or not, it could allow or not the interaction of PMSF with serine residue of the active site [113].

ROL activity-as most lipases from Rhizopus genus-has a strong 1,3-regiospecificity that makes its activity interesting for several industrial processes such as fat and oil modification for structured lipids production $[16,55,75,99]$. Nevertheless, Li et al. [114] reported, while studying ROL methanolysis performance, that this lipase was not regiospecific although showed a preference to 1,3-positions. These results were lately confirmed with Rhizopus arrhizus (=oryzae) lipase [115]. However, Okumura et al. and Song et al. [101,116] stated that Rhizopus delemar (=oryzae) and R. oryzae lipases, respectively, do not hydrolyse the ester bond in position 2. Afterwards, Canet et al. and Cao et al. $[117,118]$ proved that mature ROL exhibits a negligible activity on 2-monoolein highlighting that the lipase has a strong 1,3-regioespecificity. The observed dissimilarities amongst different works might be due to the different employed reaction conditions that could enhance spontaneous acyl-migration, or the presence of the 28 amino acids of the prosequence that has already been described to have an effect on lipase specificity [39,63]. Besides 1,3-regiospecificity, substrate specificity of ROL has been also widely studied. Many of the published works are based on the employment of $p$-nitrophenol esters of different carbon-chain length. For instance, ROL isolated and characterised by Adak et al. [104] was reported to be more specific to long carbon-chain $p$-nitrophenol esters, concretely to $p$-nitrophenol palmitate (C16). Guillen et al. [90] reported a similar trend for rROL produced in K. phaffii and, although a higher specificity to short carbon-chain $p$-nitrophenol esters was detected for proROL, the presence of esterases in the commercial product was concluded to be the reason. In fact, Tako et al. [74] also observed that the longer the carbon-chain, the higher the specificity of ROL. However, in this last case, the maximum was obtained with $p$-nitrophenol dodecanoate (C12) and not palmitate. ROL substrate specificity has been also analysed with homotriacylglycerols, that is, triacylglycerols in which the three fatty acids are identical. C8 and C10 homotriacylglycerols-triacylglycerols containing three C8 and C10 fatty acids respectively - are preferably hydrolysed by ROL while it barely acts over C2 and $\mathrm{C} 4$ homotriacylglycerols. In contrast to some of the published works, some authors have also 
described that no significant differences were observed with those substrates between rROL and proROL $[65,73,75,90]$.

Lipases are widely known for their capacity to carry out synthesis reactions in non-aqueous mediums. In fact, as previously mentioned, this capacity makes them relevant for many industrial processes in which these reactions are needed, or the solubility of substrates/products requires the use of organic solvents. Therefore, the higher the lipase stability in these solvents, the more suitable the lipase for industrial application [43]. ROL has been extensively described as a tolerant enzyme to non-aqueous solvents $[68,75,94]$, particularly in alkanes and long-chain alcohols such as hexane and dodecanol respectively. However, polar solvents like acetone or short-chain alcohols have an important negative effect on the enzyme because they strip off the crucial bound water from the enzyme's surface [119]. In some cases, it is remarkable the different results that can be obtained between the stability of the enzyme in a solvent, such as methanol and ethanol, and the operational stability employing that solvents as substrate. For instance, methanol has proven to be more detrimental than ethanol during biodiesel synthesis while during stability assays exactly the opposite result was obtained [39].

\section{Rhizopus oryzae Lipase Production and Bioprocess Engineering}

First attempts of ROL production were made with the original fungi isolated from palm fruit $[75,94,120]$. $R$. oryzae secretes, as previously mentioned, one form of lipase with a molecular weight close to $32 \mathrm{kDa}$ - the mature sequence including 28 amino acids of its prosequence. However, a second form of ROL with a molecular weight around $29 \mathrm{kDa}$ was detected after keeping the supernatant at $6{ }^{\circ} \mathrm{C}$ for few days; i.e., the lipase form corresponding to the loss of the 28 amino acids [58]. Consequently, the distinct lipases derived from $R$. oryzae described in the literature are originated because of the different proteolytic processing and not because of the presence of different genes [56].

To increase ROL industrial production, its expression in a cell factory is mandatory. This way, production cost, bioprocess engineering and downstream complexity are minimised [16].

In Escherichia coli, the presence of disulphide bonds in ROL structure and the lack of the necessary enzymes to process fungal maturation signals were the main causes that led to the production of enzymatically inactive protein as insoluble aggregates [56]. Thereafter, active lipase was obtained at lab scale by subjecting these aggregates to a refolding process. However, the large-scale production was not implemented because of the high cost of the procedure [63]. Despite that, Di Lorenzo et al. [121], achieved the production of an active and soluble ROL and proROL using the E. coli Origami (DE3) strain and pET-11d expression system. The final specific activities of both enzymes were quite similar but the yield of proROL production was higher than ROL, likely because of the toxic effect of the latter towards the host cells.

To avoid the inherent problems of prokaryotic cell factories producing eukaryotic proteins, particularly those related to post-translational processing, eukaryotic cell factories were tested for ROL production.

The extracellular production of ROL has been studied in S. cerevisiae and K. phaffii (P. pastoris) by expressing essentially three different genes. A gene encoding the prosequence of 97 amino acids fused to the $\mathrm{N}$-terminal of the mature lipase region of 269 amino acids (proROL-gene), a gene encoding a truncated prosequence of its $28 \mathrm{C}$-terminal amino acids fused to the $\mathrm{N}$-terminal of the mature lipase region (28proROL-gene) and a gene encoding the mature lipase (rROL-gene). Regardless of proROL-gene or 28proROL-gene expression, a protein with only 28 amino acids of the prosequence plus the mature lipase (proROL) was detected. Exceptionally, the complete prosequence plus the mature lipase region (entire-proROL) was also reported with proROL-gene construction. With respect to the rROL-gene construction, jus the mature lipase (rROL) was obtained.

First attempts of producing ROL in eukaryotic platforms were made with the widely used cell factory S. cerevisiae. Takahasi et al. [65] reported that S. cerevisiae secreted two active lipases when it was transformed with the proROL-gene fused to the pre- $\alpha$-factor, the entire-proROL and proROL-the lipase 
formed after Kex2-like protease cleavage of the prosequence. In parallel, when S. cerevisiae strains were transformed with rROL-gene fused to the pre- $\alpha$ or prepro- $\alpha$ factor encoding gene, almost no activity was detected, highlighting the mentioned relevance of ROL prosequence during lipase production $[66,69,71]$.

A summary of the results obtained with these cell factories is shown in Table 3.

Table 3. Summary of E. coli and S. cerevisiae cell factories expressing Rhizopus oryzae lipase.

\begin{tabular}{|c|c|c|c|c|c|}
\hline Cell Factory & Promotor/Vector & Lipase & Production & Lipolytic Activity & Reference \\
\hline \multirow{2}{*}{ E. coli Origami DE3 } & pET11 & proROL & Intracellular & $166 \mathrm{U} \mathrm{mL}^{-1}$ & \multirow{2}{*}{ [121] } \\
\hline & pET22 & proROL & Intracellular & $82 \mathrm{U} \mathrm{mL}^{-1}$ & \\
\hline \multirow{2}{*}{ S. cerevisiae } & UPR-ICL & rROL & Extracellular & 0.29 U flask $^{-1}$ & \multirow{2}{*}[65]{} \\
\hline & UPR-ICL & proROL & Extracellular & $191 \mathrm{U} \mathrm{flask}^{-1}$ & \\
\hline
\end{tabular}

\subsection{Komogatella Phaffii Cell Factory}

Unlike the reported results with S. cerevisiae, when proROL-gene was expressed in K. phaffii cell factory, only proROL was detected in the medium, which might indicate that the activity of the Kex2-like protease is higher in this cell factory than in S. cerevisiae [67]. Moreover, rROL-gene was satisfactorily expressed and the corresponding lipase was detected in the supernatant [73].

This appropriate performance on ROL secretion, jointly with the well-known excellent characteristics of $K$. phaffii, make this yeast the most suitable cell factory for heterologous ROL production [122-125]. In addition, K. phaffi does not produce endogenous extracellular lipases or esterases [126]. Thus, downstream processes might be easier and cheaper. However, two of the bottlenecks of $K$. phaffii cell factory are transformed clones screening and selecting the best operational strategy to maximise production. To minimise this problem, the use of microbioreactor devices has been successfully implemented [127].

In the following sections, the heterologous ROL production in K. phaffi and its improvement are treated. However, it must be highlighted that owing to the different lipolytic assay conditions employed amongst the published works, a comparison between the obtained values of ROL activity in $\mathrm{U} \mathrm{ml}^{-1}$ is challenging. This value is highly dependent on substrate type, enzymatic reaction conditions as well as the equipment used [128].

\subsection{1. rROL $\mathrm{P}_{\mathrm{AOX}}$}

Regarding K. phaffii's promoters, the inducible alcohol oxidase promoter $\left(\mathrm{P}_{A O X}\right)$ remains as the most used promoter for the heterologous expression of ROL in this cell factory [16]. Since the first article, in which the functional expression of rROL in Mut ${ }^{+}$phenotype K. phaffii strain under $\mathrm{P}_{A O X}$ producing $180 \mathrm{U} \mathrm{ml}^{-1}$ was described [73], an important effort to assess the effect of different promoters, phenotypes, gene dosage, co-expression of different chaperones to reduce stress burden and different operational bioprocess strategies has been made.

All the data of production parameters and bioprocess conditions under K. phaffii are summarised in Table 4. 
Table 4. Summary of K. phaffii cell factory expressing Rhizopus oryzae lipase.

\begin{tabular}{|c|c|c|c|c|c|c|c|c|c|c|c|}
\hline Gene & Prom. & Co-expr. $\Delta$ Delet. & Phenot. & Operational Mode & $\operatorname{Pmax} \mathrm{AU} \mathrm{mL}^{-1}$ & $\mathrm{Mh}^{-1}$ & $\mathrm{q}_{\mathrm{p}} \mathrm{AU} \mathrm{gX}^{-1} h^{-1}$ & $\mathrm{Y}_{\mathrm{P} / \mathrm{X}} \mathrm{AU}_{\mathrm{gX} \mathbf{X}^{-1}}$ & $\begin{array}{l}\text { Vol. Prod. AU } \\
\mathrm{L}^{-1} \mathrm{~h}^{-1}\end{array}$ & $\begin{array}{l}\text { Spec. Vol. } \\
\text { Prod. AU } \\
\mathrm{gX}^{-1} \mathrm{~h}^{-1}\end{array}$ & Ref. \\
\hline rROL & AOX & & $\begin{array}{l}\text { Mut }^{+} \\
\text {SC }\end{array}$ & $\begin{array}{c}\text { Fed-batch } \\
\mathrm{MeOH} \text { added when } \mathrm{CO}_{2} \text { decrease }\end{array}$ & 500 & & & & 5435 & & [73] \\
\hline rROL & AOX & & $\begin{array}{c}\mathrm{Mut}^{+} \\
\mathrm{SC}\end{array}$ & $\begin{array}{c}\text { Fed-batch } \\
\mathrm{MeOH} \text { added manual control }\end{array}$ & 1334 & & & & 12,888 & 268 & [128] \\
\hline rROL & AOX & & $\begin{array}{c}\mathrm{Mut}^{+} \\
\text {SC }\end{array}$ & $\begin{array}{l}\text { Fed-batch } \\
\text { MeOH added manual control } 2 \mathrm{~g} \mathrm{~L}^{-1}\end{array}$ & 150 & 0.036 & 130 & 2470 & 3000 & 49 & [129] \\
\hline rROL & AOX & & $\begin{array}{l}\mathrm{Mut}^{+} \\
\mathrm{MC}\end{array}$ & $\begin{array}{l}\text { Fed-batch } \\
\mathrm{MeOH} \text { added manual control } 2 \mathrm{~g} \mathrm{~L}^{-1}\end{array}$ & 175 & 0.012 & 71 & 3578 & 1894 & 40 & [129] \\
\hline rROL & AOX & & $\begin{array}{l}\mathrm{Mut}^{\mathrm{s}} \mathrm{His}^{+} \\
\mathrm{SC}\end{array}$ & $\begin{array}{l}\text { Fed-batch } \\
\mathrm{MeOH} \text { added manual control } 2 \mathrm{~g} \mathrm{~L}^{-1}\end{array}$ & 205 & 0.005 & 83 & 5775 & 2246 & 63 & [129] \\
\hline rROL & AOX & & $\begin{array}{l}\mathrm{Mut}^{\mathrm{S}} \mathrm{His}^{-} \\
\mathrm{MC}\end{array}$ & $\begin{array}{l}\text { Fed-batch } \\
\text { MeOH added manual control } 2 \mathrm{~g} \mathrm{~L}^{-1}\end{array}$ & 270 & 0.004 & 59 & 7500 & 1500 & 46 & [129] \\
\hline rROL & AOX & & $\mathrm{Mut}^{+}$ & $\begin{array}{l}\text { Fed-batch } \\
\text { MeOH controlled } 3 \mathrm{~g} \mathrm{~L}^{-1} \mathrm{MNLFB}+ \\
\text { MLFB to maintain } 25 \% \mathrm{DO}\end{array}$ & 644 & 0.03 & 277 & 7800 & 8110 & 98 & [130] \\
\hline rROL & AOX & & $\begin{array}{l}\mathrm{Mut}^{+} \\
\mathrm{SC}\end{array}$ & $\begin{array}{c}\text { Fed-batch } \\
\text { Temperature limited }\end{array}$ & 534 & 0.13 & 130 & 5830 & 5200 & 57 & [130] \\
\hline rROL & AOX & & $\mathrm{Mut}^{+}$ & $\begin{array}{l}\text { Fed-batch } \\
\text { MeOH controlled } 3 \mathrm{~g} \mathrm{~L}^{-1} \mathrm{MNLFB}+ \\
\text { temperature limited }\end{array}$ & 713 & 0.02 & 161 & 6960 & 5980 & 58 & [130] \\
\hline rROL & AOX & & $\begin{array}{c}\mathrm{Mut}^{+} \\
\text {SC }\end{array}$ & $\begin{array}{c}\text { Fed-batch } \\
\mathrm{MeOH} \text { controlled } 3 \mathrm{~g} \mathrm{~L}^{-1} \mathrm{MNLFB}\end{array}$ & 280 & 0.046 & 322 & 5282 & 5406 & 102 & [131] \\
\hline rROL & AOX & & $\begin{array}{c}\mathrm{Mut}^{+} \\
\mathrm{SC}\end{array}$ & $\begin{array}{l}\text { Fed-batch } \\
\text { MNLFB } \mu=0.015 \mathrm{~h}^{-1}\end{array}$ & 135 & 0.014 & 46 & 2644 & 1857 & 36 & [131] \\
\hline rROL & AOX & & $\begin{array}{c}\mathrm{Mut}^{+} \\
\mathrm{SC}\end{array}$ & $\begin{array}{c}\text { Fed-batch } \\
\text { MeOH controlled } 3 \mathrm{~g} \mathrm{~L}^{-1} \mathrm{MNLFB} \\
\text { DO } 25 \%\end{array}$ & 368 & 0.034 & 256 & 7700 & 5490 & & [132] \\
\hline rROL & AOX & & $\begin{array}{c}\mathrm{Mut}^{+} \\
\mathrm{SC}\end{array}$ & $\begin{array}{c}\text { Continuous } \\
\text { MeOH controlled } 3 \mathrm{~g} \mathrm{~L}^{-1}\end{array}$ & & 0.02 & 0.91 & 45.7 & 1.6 & & [133] \\
\hline rROL & AOX & & $\mathrm{Mut}^{+}$ & $\begin{array}{l}\text { Continuous } \\
\mathrm{MeOH} \text { controlled } 3 \mathrm{~g} \mathrm{~L}^{-1}\end{array}$ & & 0.05 & 0.98 & 19.6 & 2.7 & & [133] \\
\hline rROL & AOX & & $\mathrm{Mut}^{\mathrm{s}}$ & $\begin{array}{l}\text { Fed-batch } \\
\mathrm{MeOH} \text { controlled } 1 \mathrm{~g} \mathrm{~L}^{-1}\end{array}$ & 490 & 0.004 & 148 & 11,236 & 4901 & 112 & [134] \\
\hline rROL & AOX & & $\begin{array}{c}\mathrm{Mut}^{\mathrm{S}} \\
\mathrm{SC}\end{array}$ & $\begin{array}{l}\text { Fed-batch } \\
\text { MeOH controlled } 2 \mathrm{~g} \mathrm{~L}^{-1} \text { Sorbitol } \\
\text { exponential feeding rate } 0.02 \mathrm{~h}^{-1}\end{array}$ & 488 & 0.02 & 326 & 10,369 & 6346 & 135 & [135] \\
\hline rROL & AOX & & $\mathrm{Mut}^{\mathrm{S}}$ & $\begin{array}{l}\text { Fed-batch } \\
\text { MeOH controlled } 2 \mathrm{~g} \mathrm{~L}^{-1} \text { Glycerol } \\
\text { exponential feeding rate } 0.02 \mathrm{~h}^{-1}\end{array}$ & 471 & 0.025 & 149 & 6373 & 5416 & 73 & [136] \\
\hline rROL & FLD1 & & $\begin{array}{c}\mathrm{Mut}^{+} \\
\text {SC }\end{array}$ & $\begin{array}{c}\text { Fed-batch } \\
\text { Manual SNLFB } 8 \mathrm{~g} \mathrm{~L}^{-1}\end{array}$ & 385 & 0.02 & 244 & 7634 & 4379 & 87 & [137] \\
\hline rROL & FLD1 & $\begin{array}{l}\text { GAP HAC1 } \\
\text { S. cerevisiae }\end{array}$ & $\begin{array}{c}\mathrm{Mut}^{+} \\
\text {SC }\end{array}$ & $\begin{array}{c}\text { Fed-batch } \\
\text { MLFB } \mu=0.005 \mathrm{~h}^{-1}\end{array}$ & 73 & 0.005 & 52 & 3630 & 1147 & 57 & [138] \\
\hline
\end{tabular}


Table 4. Cont

\begin{tabular}{|c|c|c|c|c|c|c|c|c|c|c|c|}
\hline Gene & Prom. & Co-expr. $\Delta$ Delet. & Phenot. & Operational Mode & $\operatorname{Pmax} \mathrm{AU} \mathrm{mL}^{-1}$ & $\mathrm{Mh}^{-1}$ & $\mathrm{q}_{\mathrm{p}} \mathrm{AU}_{\mathrm{gX}} \mathrm{X}^{-1} \mathrm{~h}^{-1}$ & $\mathrm{Y}_{\mathrm{P} / \mathrm{X}} \mathrm{AU}_{\mathrm{gX}} \mathbf{1}^{-1}$ & $\begin{array}{l}\text { Vol. Prod. AU } \\
\mathrm{L}^{-1} \mathrm{~h}^{-1}\end{array}$ & $\begin{array}{l}\text { Spec. Vol. } \\
\text { Prod. AU } \\
\mathrm{gX}^{-1} \mathrm{~h}^{-1}\end{array}$ & Ref. \\
\hline rROL & FLD1 & $\Delta$ GAS1 & $\begin{array}{l}\mathrm{Mut}^{+} \\
\mathrm{SC}\end{array}$ & $\begin{array}{c}\text { Fed-batch } \\
\text { MLFB } \mu=0.005 \mathrm{~h}^{-1}\end{array}$ & 240 & 0.006 & 145 & 7172 & 2790 & 82 & {$[138]$} \\
\hline rROL & FLD1 & $\begin{array}{l}\Delta \text { GAS1 GAP HAC1 } \\
\text { S. cerevisiae }\end{array}$ & $\begin{array}{c}\mathrm{Mut}^{+} \\
\text {SC }\end{array}$ & $\begin{array}{c}\text { Fed-batch } \\
\text { MLFB } \mu=0.005 \mathrm{~h}^{-1}\end{array}$ & 206 & 0.005 & 206 & 13,186 & 3274 & 144 & {$[138]$} \\
\hline proROL & AOX & & $\begin{array}{c}\mathrm{Mut}^{+} \\
\mathrm{SC}\end{array}$ & $\begin{array}{l}\text { Fed-batch } \\
\text { Methanol controlled at } 0.1 v / v\end{array}$ & 12,019 & & & & & & [139] \\
\hline proROL & AOX & & $\begin{array}{l}\mathrm{Mut}^{+} \\
\text {MC }\end{array}$ & $\begin{array}{c}\text { Fed-batch } \\
\text { Methanol controlled at } 3 \mathrm{~g} \mathrm{~L}^{-1}\end{array}$ & 140 & & & 4375 & 1521 & & [67] \\
\hline rROL & AOX & & $\begin{array}{l}\mathrm{Mut}^{+} \\
\mathrm{MC}\end{array}$ & $\begin{array}{l}\text { Fed-batch } \\
\text { Methanol controlled at } 3 \mathrm{~g} \mathrm{~L}^{-1}\end{array}$ & 195 & & & 5417 & 2130 & & [67] \\
\hline proROL & AOX & & $\begin{array}{l}\mathrm{Mut}^{+} \\
\text {MC }\end{array}$ & $\begin{array}{l}\text { Fed-batch } \\
\text { Methanol-sorbitol to maintain DO } \\
20-50 \%\end{array}$ & 20,500 & & & 175,213 & 178,261 & 1524 & {$[140]$} \\
\hline proROL & AOX & Ubc1 & $\begin{array}{l}\mathrm{Mut}^{+} \\
\text {MC }\end{array}$ & $\begin{array}{c}\text { Fed-batch } \\
\text { Methanol-sorbitol to maintain DO } \\
20-50 \%\end{array}$ & 28,600 & & & 223,883 & 223,833 & 1865 & {$[140]$} \\
\hline proROL & AOX & Hrd1 & $\begin{array}{l}\mathrm{Mut}^{+} \\
\mathrm{MC}\end{array}$ & $\begin{array}{c}\text { Fed-batch } \\
\text { Methanol-sorbitol to maintain DO } \\
20-50 \%\end{array}$ & 29,600 & & & 229,922 & 233,543 & 1810 & [140] \\
\hline proROL & AOX & $\mathrm{Ubc} 1+\mathrm{Hrd} 1$ & $\begin{array}{l}\mathrm{Mut}^{+} \\
\text {MC }\end{array}$ & $\begin{array}{c}\text { Fed-batch } \\
\text { Methanol-sorbitol to maintain DO } \\
20-50 \%\end{array}$ & 33,900 & & & 280,165 & 266,929 & 2206 & [140] \\
\hline proROL & AOX & Ssa4 + Sso2 + Bmh2 & $\begin{array}{l}\mathrm{Mut}^{+} \\
\mathrm{MC}\end{array}$ & $\begin{array}{c}\text { Fed-batch } \\
\text { Methanol-sorbitol to maintain DO } \\
20-50 \%\end{array}$ & 36,578 & & & 302,000 & 290,000 & 2206 & [141] \\
\hline proROL & AOX & $\begin{aligned} & \text { Ssa4 }+ \text { Sso2 } \\
+ & \text { Bmh2 }+ \text { Vhb9 }\end{aligned}$ & $\begin{array}{l}\mathrm{Mut}^{+} \\
\mathrm{MC}\end{array}$ & $\begin{array}{c}\text { Fed-batch } \\
\text { Methanol-sorbitol to maintain DO } \\
20-50 \%\end{array}$ & 41,700 & & & 345,000 & 331,000 & 2206 & [141] \\
\hline proROL & GAP & & $\begin{array}{c}\mathrm{Mut}^{+} \\
\mathrm{SC}\end{array}$ & $\begin{array}{l}\text { Fed-batch } \\
\text { Constant feeding rate to maintain DO } \\
20-40 \%\end{array}$ & 11 & & & & 131 & 1 & [62] \\
\hline proROL & GAP & $\begin{array}{l}\text { Glycosylation } \\
\text { Mutant A + B }\end{array}$ & $\begin{array}{c}\mathrm{Mut}^{+} \\
\mathrm{SC}\end{array}$ & $\begin{array}{c}\text { Fed-batch } \\
\text { Constant feeding rate to maintain DO } \\
20-40 \%\end{array}$ & 2600 & & & & 30,952 & 221 & [62] \\
\hline 28proROL & AOX & & $\begin{array}{c}\mathrm{Mut}^{+} \\
\text {SC }\end{array}$ & $\begin{array}{c}\text { Fed-batch } \\
\text { MNLFB } \mu=0.015 \mathrm{~h}^{-1}\end{array}$ & 219 & 0.011 & 57 & 5264 & 2763 & 49 & [39] \\
\hline 28proROL & AOX & & $\mathrm{Mut}^{+}$ & $\begin{array}{c}\text { Fed-batch } \\
\text { MNLFB } \mu=0.045 \mathrm{~h}^{-1}\end{array}$ & 147 & 0.038 & 69 & 1908 & 2782 & 44 & [39] \\
\hline 28proROL & AOX & & $\begin{array}{l}\mathrm{Mut}^{+} \\
\text {SC }\end{array}$ & $\begin{array}{l}\text { Fed-batch } \\
\text { MNLFB } 3 \mathrm{~g} \mathrm{~L}^{-1}\end{array}$ & 358 & 0.065 & 308 & 4972 & 7160 & 99 & [39] \\
\hline
\end{tabular}


A comparative study of the effect of ROL gene dosage and K. phaffii strain phenotype demonstrated that, for a single rROL-gene copy strain, the highest production and specific volumetric productivity were reached with the methanol slow consumption phenotype $\left(\mathrm{Mut}^{\mathrm{S}}\right)$. Despite that, the maximum volumetric productivity was reached with methanol plus consumption phenotype (Mut ${ }^{+}$), because of the greater specific growth rate associated to this phenotype in contrast to Mut ${ }^{\mathrm{S}}$. Additionally, regarding gene dosage, it was described that the higher the amount of gene copies transformed into the K. phaffii strain genome, the higher the lipase production. However, this increase showed a negative effect on the specific production rate and productivities, particularly for Mut ${ }^{\mathrm{S}}$ phenotype strain. This result was probably caused by the great amount of rROL-gene copies contained in Mut ${ }^{\mathrm{S}}$ strain, 23-24, in comparison to Mut ${ }^{+}$(5-6 copies) [129]. Moreover, this study was carried out without a robust methanol concentration control, and it is well-known that the maintenance of a constant optimal methanol concentration during the fed-batch (methanol non-limited fed-batch, MNLFB) is necessary to get not only the maximal production but also a reproducible bioprocess.

In this sense, the implementation of a robust methanol on-line control strategy to ensure a constant methanol concentration (MNLFB) in the bioreactor [134] allowed a substantial increase of lipase production, specific production rates and productivities in $\mathrm{Mut}^{+}$phenotype strain. In fact, a methanol set-point concentration of $3 \mathrm{~g} \mathrm{~L}^{-1}$ was found to be the optimum for rROL production, specific production rate, product-biomass yield and volumetric productivity [131]. These values were almost twice the results obtained in previous experiments with manual methanol control [129]. Additionally, when a methanol limiting fed-batch (MLFB) strategy was applied, that is, a pre-programed exponential feeding rate of methanol to maintain a constant specific growth rate, all production parameters were dramatically lower than with MNLFB strategy. These results suggested a possible negative effect of rROL production on K. phaffii depending on the operational strategy selected [131].

Dissolved oxygen (DO) set-point has been described as a significant parameter during rROL production. A DO set-point around $25 \%$ was found to be the best operational condition to achieve the highest specific growth, methanol consumption, oxygen uptake, $\mathrm{CO}_{2}$ production and rROL-specific production rates. However, the highest product-biomass yield $\left(\mathrm{Y}_{\mathrm{P} / \mathrm{X}}\right)$ was achieved with a lower $\mathrm{DO}$ value $(10 \%)$ [132].

Alternative operational strategies have been assessed to avoid oxygen limitation issues in high cell densities fed-batch cultures, for instance, the combination of MNLFB with methanol or temperature-limited fed-batch strategies. In this line, Surribas et al. [130] reported higher rROL production and $\mathrm{Y}_{\mathrm{P} / \mathrm{X}}$, although lower specific production rate.

Moreover, despite oxygen limitation problems, the feeding strategy, as mentioned before, is a key factor in rROL production in K. phaffii. Therefore, in order to improve the substrate feeding strategy, a mathematical model was applied to select the optimal methanol feeding rate achieving significant improvements in final titre and productivity-2.2- and 3.4-fold higher respectively-in comparison to the best standard pre-programmed exponential feeding strategy (MLFB). Nevertheless, the obtained values were quite similar to the most promising control algorithm of the optimal methanol concentration strategy (MNLFB, $3 \mathrm{~g} \mathrm{~L}^{-1}$ ) [142].

In the case of $\mathrm{Mut}^{\mathrm{S}}$ phenotype strain, when the MNLFB strategy was applied, the greatest ROL production, $\mathrm{Y}_{\mathrm{P} / \mathrm{X}}$ and productivities were obtained with a constant methanol concentration of $1 \mathrm{~g} \mathrm{~L}^{-1}$, while the optimal value for $\mathrm{Mut}^{+}$phenotype strain was $3 \mathrm{~g} \mathrm{~L}^{-1}$. In these conditions, although the lipase production and $\mathrm{Y}_{\mathrm{P} / \mathrm{X}}$ were around two-fold higher than with $\mathrm{Mut}^{+}$phenotype strain, the specific production rate was 2-fold lower, because of the lower specific growth rate $\left(0.013 \mathrm{~h}^{-1}\right)$ of Mut $\mathrm{S}$ compared to $\mathrm{Mut}^{+}\left(0.046 \mathrm{~h}^{-1}\right)$. Therefore, specific and volumetric productivities of both phenotypes were quite similar [134]. Considering these results, in order to select the best methanol consumption phenotype, not only the production parameters, but also the operational implementation feasibility should be taken into account. In consequence, as methanol consumption, oxygen demand and heat generation are lower in $\mathrm{Mut}^{\mathrm{S}}$ than in $\mathrm{Mut}^{+}$, the former has a greater implementation potential from the bioprocess point of view. 
In order to improve rROL production and minimise the proteolysis in $\mathrm{Mut}^{\mathrm{S}}$ phenotype strain cultures, different operational strategies have been studied. Li et al. [143] described that maintaining a constant methanol concentration during the fed-batch cultivation showed a better lipase production than adjusting methanol feeding rate to keep DO over 35\% (DO-stat). However, the former strategy needs to be complemented to avoid proteases expression and lipase degradation. Besides, modification of medium composition, pre-induction, osmotic stress and temperature have been also described as an important factor in $\mathrm{rROL}$ production.

The productivity of $\mathrm{Mut}^{\mathrm{S}}$ phenotype strain cultures can be improved by using co-substrates jointly with the methanol during the bioprocess. In this sense, because of the repression of $\mathrm{P}_{A O X}$ by glycerol and glucose, sorbitol was chosen as the most suitable co-substrate- $\mathrm{P}_{A O X}$ repression by sorbitol happened only at concentrations over $40 \mathrm{~g} \mathrm{~L}^{-1}$. Interestingly, the sorbitol assimilation profile was different depending on the selected Mut phenotype. In Mut ${ }^{\mathrm{S}}$, both substrates were consumed simultaneously, getting not only higher specific growth rates, but also higher secretion levels. However, this effect was not observed in $\mathrm{Mut}^{+}$phenotype strains in which substrates consumption was sequential [144].

When a systematic study comparing fed-batch cultures at different constant methanol concentration set-points and different specific growth rates of sorbitol was made with $\mathrm{Mut}^{\mathrm{S}}$, the optimal conditions were at methanol set-point of $2 \mathrm{~g} \mathrm{~L}^{-1}$ and sorbitol specific growth rate of $0.01 \mathrm{~h}^{-1}$. Under these conditions, all production parameters were increased in comparison to the best results obtained using methanol as the sole carbon source at a methanol set-point of $1 \mathrm{~g} \mathrm{~L}^{-1}$. Interestingly, the use of co-substrate strategy overcame partially the physiological bottlenecks detected at different levels in the rROL production bioprocess. According to Arnau et al. [135] the addition of sorbitol during the methanol induction phase avoided the severe decrease of the specific production rate obtained when methanol was used as a sole carbon source. However, the drawback of using sorbitol as the co-substrate is its maximum specific growth rate in $K$. phaffii, which is too low $\left(0.02 \mathrm{~h}^{-1}\right)$, similar to the value growing in methanol for $\mathrm{Mut}^{\mathrm{S}}$ strain. Thus, the productivity could be affected because of the long-time bioprocess. Consequently, to overcome this problem, glycerol was also tested as co-substrate. This substrate has a $\mu_{\text {MAX }}$ around $0.2 \mathrm{~h}^{-1}, 10$-fold higher than K. phaffii growing in sorbitol. However, although glycerol was fed under limiting conditions, the productivity of the bioprocess decreased dramatically when the specific growth rate of glycerol was higher than $0.02 \mathrm{~h}^{-1}$, highlighting the repressive effect of this compound on $\mathrm{P}_{A O X}$ [136]. Besides, the effect of dilution rate on chemostat cultures with a $\mathrm{Mut}^{+}$phenotype strain, using glycerol as the co-substrate, revealed that the optimal dilution rate was between 0.04 and $0.06 \mathrm{~h}^{-1}$ in terms of maximum productivity. When these results were compared to the optimal dilution rate of rROL production $\left(0.02 \mathrm{~h}^{-1}\right)$ using methanol as the sole carbon source, the productivity was close to two-fold higher, but $\mathrm{Y}_{\mathrm{P} / \mathrm{X}}$ followed the opposite trend. Thus, in terms of productivity, the mixed feeding strategy (glycerol-methanol) might be potentially applied in fed-batch cultures with promising results opening new lines of research for the future [133].

\subsection{2. $r R O L P_{F L D 1}$}

rROL-gene has been also expressed under the inducible formaldehyde dehydrogenase 1 promoter $\left(\mathrm{P}_{F L D 1}\right)$, which has been reported as a strong and independent promoter induced by both methanol as sole carbon source and methylamine as the sole nitrogen source. Besides, $\mathrm{P}_{F L D 1}$ has been described to be strongly repressed by an excess of either glycerol or glucose but not sorbitol. In fact, even though the combination of methanol-methylamine showed a synergetic effect on ROL production levels under this promotor, the combination of sorbitol as sole carbon source and methylamine as sole nitrogen source enabled, for the very first time, ROL production in a methanol-free high cell density fed-batch culture. This way, the use of methanol is avoided and substituted by methylamine, which is a less flammable and volatile $P_{F L D 1}$ inducer than the former $[145,146]$.

Different operational fed-batch strategies were tested to assess the performance of $\mathrm{P}_{F L D 1}$. The best outcome was obtained by maintaining a constant concentration of $8 \mathrm{~g} \mathrm{~L}^{-1}$ of sorbitol by feeding the culture media with a stock solution of sorbitol and methylamine-stoichiometric ratio of $0.118 \mathrm{~g}$ 
methylamine per $g$ of sorbitol [137]. Under these conditions, the production was 1.37-fold higher than the best result reported with Mut $^{+}$phenotype strain by Barrigon et al. [131], although 0.58-fold lower than the best outcome described for $\mathrm{Mut}^{\mathrm{S}}$ phenotype by Arnau et al. [135], both under $\mathrm{P}_{A O X}$. In any case, $\mathrm{P}_{F L D 1}$ was successfully employed for $\mathrm{rROL}$ production under methanol-free high cell density fed-batch strategy [137].

Transcriptomic studies using $\mathrm{P}_{F L D 1}$ revealed that rROL overexpression and secretion seem to trigger the unfolding protein response (UPR) in K. phaffii, resulting in a physiological bottleneck for the bioprocess production. The study pointed out a complex response to both dynamic environmental conditions (bioprocess) and endogenous stress factors (omics) [147]. In this sense, the co-expression of rROL under inducible $\mathrm{P}_{F L D 1}$ and the S. cerevisiae UPR transcriptional factor (HAC1) under constitutive $\mathrm{P}_{\text {GAP }}\left(\right.$ ROL_HAC1) showed-working at the same specific growth rate $\left(0.005 \mathrm{~h}^{-1}\right)$-two-fold higher values of lipase production and volumetric productivity; and close to three-fold higher values on $\mathrm{Y}_{\mathrm{P} / \mathrm{X}}$ and specific productivity. In parallel, this co-expression system reduced intracellular binding proteins (BiP) levels which has been related to UPR triggering [138]. On the other hand, in order to improve the possible secretion bottlenecks of rROL, a new rROL-producing strain was constructed with deletion of the GAS1 gene (ROL_AGAS1), a $\beta$ 1-3-glucanosytransglycosylase which plays a key role in yeast cell assembly. The rROL production parameters of this strain were clearly increased although a substantial reduction of $\mu_{\mathrm{MAX}}$ was observed [148]. Finally, the double mutant $R O L \_H A C 1-R O L \_\triangle G A S 1$ was tested and the synergetic effect of these engineering strategies was confirmed [138]. However, the specific production rate and intracellular $\mathrm{rROL}$ levels reflected a complex interaction of these modifications with physiological aspects, including energy metabolism and growth conditions that require further research. Nevertheless, considering all these results, transcriptomics studies have provided new insights into microorganisms' modification in general and K. phaffii in particular [149]. Consequently, further research in this field will allow a better understanding of all the bottlenecks present in the heterologous production of proteins.

\subsection{3. proROL $\mathrm{P}_{\mathrm{AOX}}$}

Wang et al. [68] reported proROL production under $\mathrm{P}_{A O X}$ in $\mathrm{Mut}^{+}$phenotype strain. Fifty-litre bioreactors were employed for high cell density fed-batch cultures with methanol, whose concentration was kept stable by monitoring the dissolved oxygen (DO) content and maintaining it over $20 \%$. A maximum activity of $21,000 \mathrm{U} \mathrm{mL}^{-1}$ was obtained with a final biomass concentration of $197 \mathrm{~g} \mathrm{~L}^{-1} \mathrm{DCW}$.

Nitrogen concentration $\left(\mathrm{NH}_{4}^{+}\right)$has been described as a relevant factor during proROL production in high cell density fed-batch cultures with $\mathrm{Mut}^{+}$phenotype strain [139]. The optimum $\mathrm{NH}_{4}{ }^{+}$ concentration to maximise lipase production $\left(12,019 \mathrm{U} \mathrm{mL}^{-1}\right)$ was found to be $440 \mathrm{mmol} \mathrm{L}-1$. Furthermore, this concentration of $\mathrm{NH}_{4}^{+}$prevented protease production and has a significant impact on the carbon metabolism and energy regeneration.

Interestingly, with proROL-producing strain, as it was observed with $\mathrm{rROL}$, the recombinant lipase produced with $\mathrm{Mut}^{\mathrm{S}}$ phenotype was more active and more stable to changes of induction time and methanol concentration than the lipase produced with $\mathrm{Mut}^{+}$strain [100].

The comparison of strains harbouring multicopy of proROL and rROL-genes has also been studied in fed-batch cultures under $\mathrm{P}_{A O X}$ and $\mathrm{Mut}^{+}$phenotype with methanol concentration control at $3 \mathrm{~g} \mathrm{~L}^{-1}$. As it was previously commented, the truncated lipase proROL, with only the $28 \mathrm{C}$-terminal amino acids of the prosequence fused to the mature sequence was detected in the medium with proROL-gene harbouring strain. The amounts of enzyme secreted were quite similar, $91 \mathrm{mg} \mathrm{L}^{-1}$ for proROL and $80 \mathrm{mg} \mathrm{L}^{-1}$ for rROL. The characterisation of both lipases showed the importance of the prosequence in terms of thermostability and relative activity towards triacylglycerols [67].

Jiao et al. [140], proved that proROL activities were enhanced along with the increase of proROL-gene copy number up to five copies. At higher gene copy number, lipolytic activity decreased. Authors also tried to alleviate cellular stress via ER-associated protein degradation (ERAD) expression. In this sense, two ERAD-related genes $U b c 1$ and $H r d 1$ were co-expressed together with the proROL-gene 
in high cell densities fed-batch cultures. Sorbitol was employed as a co-substrate jointly with methanol and DO was maintained between 25 and $50 \%$. The production reached with the double mutant Ubc1-Hrd1 was higher than the strains co-expressing only one of the ERAD-relates genes. Therefore, the double mutant showed a synergetic effect on proROL production [140].

Furthermore, the co-expression of molecular chaperones ERO1p and PDI has been described to increase the production of proROL [150]. However, no effect was observed by increasing Pdi gene copy number. In parallel, the effect on proROL production of 10 helper factors was studied. Between them Ssa4, Bmh2 and Sso2-all participating in protein secretion-and Vhb-to alleviate oxygen intake problems-were tested for proROL expression enhancement. Results confirmed that proROL production was improved in fed-batch bioprocess with a strain containing 5 copies of proROL and the co-expression of these protein helpers [141].

\subsection{4. $\mathrm{rROL}$ and proROL $\mathrm{P}_{\mathrm{GAP}}$}

rROL and proROL production under the constitutive promoter GAP has not been extensively studied. In fact, in our lab, the expression of rROL under $\mathrm{P}_{G A P}$ has not been successful. However, Yu et al. [62] reported significant proROL production levels after engineering the N-glycosylation pattern of the prosequence. In fact, the production of the modified proROL was 218-fold higher than the parent proROL, highlighting the rational design of $\mathrm{N}$-glycosylation sites as an efficient way to enhance proROL secretion under $P_{G A P}$.

\subsubsection{8proROL $\mathrm{P}_{\mathrm{AOX}}$}

Recently a new gen construction (28proROL-gene) consisting in the $28 \mathrm{C}$-terminal amino acids of the prosequence fused to the N-terminal of mature sequence of ROL has been expressed under $\mathrm{P}_{A O X}$. In batch cultures, growth kinetics, production and yields were higher for proROL-producing strain than rROL. In addition, under similar fed-batch operational strategies, lipase production and volumetric productivity were always higher in 28proROL-gene harbouring strain than rROL-gene, suggesting a stress reduction during lipase expression caused by the presence of the 28 amino acids of the prosequence. Consequently, UPR phenomena might not be triggered to the same extent as in rROL production. After fed-batch culture downstream, the obtained free proROL showed a higher stability than $\mathrm{rROL}$, making it more appropriate as an industrial biocatalyst [39].

The 28proROL-gene has been expressed under $P_{G A P}$ at similar production levels than under $\mathrm{P}_{A O X}$ in Valero's group (data not published). These results are relevant in order to carry out friendlier bioprocess engineering avoiding the use of methanol.

\subsubsection{Whole Cells}

Hama et al. reported that $\mathrm{rROL}$ and proROL are located in different regions in $R$. oryzae cells, proROL in the cell wall and rROL bound to the cell membrane. Besides, these cells have been successfully employed as whole cells biocatalysts (WCB) in many relevant biotransformations, for instance, for enzymatic biodiesel production [151,152]. It must be highlighted that the fatty acid composition of the membrane has been reported to influence lipase activity and stability during biodiesel reactions [153].

Modified S. cerevisiae strains producing ROL have also been used as WCB $[154,155]$. Matsumoto et al. [154] reported the intracellular production of proROL in S. cerevisiae under the $5^{\prime}$ upstream region of the isocitrate lyase gene of Candida tropicalis (UPR-ICL). Additionally, the expression of the lipase under the constitutive promoter glyceraldehyde-3-phosphate dehydrogenase was also studied. However, this system did not improve the results obtained with UPR-ICL.

proROL was successfully expressed under $\mathrm{P}_{A O X}$ control and displayed on $\mathrm{Mut}^{+}$phenotype K. phaffii cell surface using the Flo1P anchor system previously developed in S. cerevisiae. The obtained WCB showed higher thermal stability than free enzyme [156]. Additionally, a similar approach using 
Sed1p anchor protein was studied in a Mut ${ }^{\mathrm{S}}$ phenotype. In the same sense, the obtained biocatalysts was stable in a wide range of temperatures and $\mathrm{pH}$ [157].

\section{Industrial Applications of Rhizopus oryzae Lipase}

The 1,3-regiospecificity and catalytic versatility make ROL appropriate for improving the sustainability of food, pharmaceutical and energy industry $[16,21,158]$.

\subsection{Biodiesel Production}

Because of petroleum depletion and environmental concerns, in the past decade, biodiesel (mono-alkyl esters of long chain fatty acids) is gathering significant interest as a renewable, biodegradable and more environmentally friendly alternative to fossil fuels. Biodiesel can be classified into three different generations based on the source from which it is derived. First-generation biodiesel is synthesised with edible-oils such as soybean or sunflower oils. Therefore, it might cause the so-called "food vs. fuel" ethical issue because of the use of food and agricultural lands for biofuel production [159]. In order to prevent this problem, alternative substrates have emerged for biodiesel synthesis, leading to second- and third-generation biodiesel production. The former uses non-edible oils that are not considered for human consumption and are produced from crops that, even if they require lands, are generally from poor lands not useful for agriculture. Meanwhile, third-generation biodiesel completely avoids ethical issues by using microbial lipids and oleaginous wastes such as oils from microalgae or oleaginous yeasts and waste cooking oils (WCO) respectively [160-163]. Additionally, there is a fourth-generation biodiesel that is at its preliminary research stages and is based on man-made biological tools, that is, biodiesel producing genetically modified microorganisms [164,165].

Typically, these alternative substrates, those yielding second- and third-generation biodiesel, have a higher free fatty acid (FFA) content, which can make biodiesel production through chemical synthesis - the most common process for current industrial biodiesel production-more complex because previous operation of FFA neutralisation is required to avoid soap formation, an usual side reaction when substrates with high FFA content and basic catalysts are employed [161,166,167]. In this context, enzymatic biodiesel synthesis with lipases arises as an alternative owing to its several advantages such as the milder reaction conditions, less water consumption, easier downstream and particularly, the absence of side reactions and consequently the capacity of employing substrates with high FFA content $[168,169]$. In fact, substrates with initial high amounts of FFA have been reported to enhance enzymatic biodiesel synthesis reaction rate and biocatalysts operational stability $[168,170,171]$. Given all the advantages, numerous lipases have been studied in this biotransformation with significant results, such as the lipases of Candida rugosa [172,173], Candida antartica $[174,175]$ and Burkholderia cepacia $[176,177]$.

In the seeking for the best lipase to make enzymatic biodiesel feasible at industrial scale, lipases' regiospecificity has become a crucial trait. Non-specific enzymes produce mono-alkyl esters and glycerol, which is an undesired by-product of the transesterification reaction that has been described to hinder reaction progress or even affect negatively on enzymes stability and biodiesel downstream [178]. Conversely, 1,3-regioespecific lipases, avoid glycerol formation by producing 2-monoacylglycerol which acts as a lubricant and in certain amount, upgrades biodiesel characteristics [179-181]. Furthermore, monoacylglycerols can improve the cost-effectiveness of a biodiesel biorefinery as they are more valuable products than glycerol because of their utility in pharmaceutical and food industry as emulsifiers [182-184]. Consequently, ROL has been widely studied in biodiesel production because of its regiospecificity.

Considering biodiesel ethical issues, even if several studies have employed ROL with edible oils such as olive [185], rapeseed [186,187], soybean [188-191] and sunflower [192,193] oils—commonly as model substrates for research-most of the published works have focused on the use of alternative substrates (Table 5). Jatropha curcas oil is one of the non-edible oils with higher potential for second-generation biodiesel production, probably because of the easy cultivation process and 
worldwide spread of the plant [194]. Rodrigues et al. [195] reported yields close to the theoretical $100 \%$-real $66 \%$ considering ROL 1,3-regioespecificity-and high operational stability of the biocatalysts. In Table 5 are detailed other studies with promising results using this substrate as well as other non-edible oils like Pistacia chinensis bge oil [196], Tung oil [95], Calophyllum inophyllum oil [197] and alperujo oil (olive pomace) [181]. 
Table 5. Summary of biodiesel production with Rhizopus oryzae lipase as main biocatalyst.

\begin{tabular}{|c|c|c|c|c|c|c|c|}
\hline Substrates & Lipase & Immobilisation Technique & Reactor Type & Stepwise Addition & Biodiesel Generation & $\begin{array}{l}\text { Yield-Conversion/ } \\
\text { Operational Stability }\end{array}$ & Ref. \\
\hline $\mathrm{OO}+\mathrm{MeOH}$ & rROL & IA onto ReliZyme ${ }^{\mathrm{TM}}$ OD 403M & PBR & Yes & 1st & Y: PBR $49.1 \%$ OS: second batch $44.8 \%$ & [185] \\
\hline $\mathrm{OO}+\mathrm{MeOH}$ & $\mathrm{rROL}$ & IA onto ReliZyme ${ }^{\mathrm{TM}}$ OD $403 \mathrm{M}$ & STR & Yes & 1st & Y: STR 33.56\% OS: second batch 7.7\% & [185] \\
\hline $\mathrm{RO}+\mathrm{MeOH}$ & proROL & WCB over agar plate & SLLB & No & 1st & No biodiesel production & [186] \\
\hline $\mathrm{RO}+\mathrm{EtOH}$ & proROL & WCB over agar plate & SLLB & No & 1st & No biodiesel production & [186] \\
\hline $\mathrm{RO}+\mathrm{MeOH}$ & proROL & WCB over agar plate & SGLB & No & 1 st & Y: $58 \%$ & [186] \\
\hline $\mathrm{RO}+\mathrm{EtOH}$ & proROL & WCB over agar plate & SGLB & No & 1 st & $Y: 72 \%$ & [186] \\
\hline Crude $\mathrm{CO}+\mathrm{MeOH}$ & proROL & Free enzymes & $\mathrm{BR}$ & Yes & 1st & $Y: 68.56 \%$ & [187] \\
\hline Crude $\mathrm{CO}+\mathrm{MeOH}$ & proROL-CRL & Free enzymes & $\mathrm{BR}$ & Yes & 1st & Y: $84.25 \%$ & [187] \\
\hline Crude $\mathrm{CO}+\mathrm{MeOH}$ & proROL-CRL & $\mathrm{CI}$ onto functionalised silica gel & $\mathrm{BR}$ & Yes & 1st & $Y: 88.9 \%$ & [187] \\
\hline $\mathrm{SYO}+\mathrm{MeOH}$ & proROL & WCB immobilised into BSPs & $\mathrm{BR}$ & Yes & 1 st & Y: $82.2 \%$ OS: after 6 cycles almost all activity loss & [188] \\
\hline $\mathrm{SYO}+\mathrm{MeOH}$ & proROL & CI WCB immobilised onto BSPs & $\mathrm{BR}$ & Yes & 1st & Y: $92.2 \%$ OS: after 6 cycles no loss of activity & [188] \\
\hline $\mathrm{SYO}+\mathrm{EtOH}$ & proROL & $\begin{array}{l}\text { IA onto microporous resin } \\
\text { NKA (polystyrene) }\end{array}$ & BR & Yes & 1 st & Y: $58.5 \%$ & [189] \\
\hline $\mathrm{SYO}+\mathrm{EtOH}$ & proROL-CRL & $\begin{array}{l}\text { IA onto microporous resin } \\
\text { NKA (polystyrene) }\end{array}$ & BR & Yes & 1st & Y: $80.8 \%$ & [189] \\
\hline $\mathrm{SYO}+\mathrm{EtOH}$ & $\begin{array}{l}\text { proROL-Novozyme } \\
\quad 435\end{array}$ & $\begin{array}{l}\text { proROL: IA onto microporous resin } \\
\text { NKA (polystyrene). Novozyme } \\
\text { 435: IA onto Lewatit VP OC } 1600\end{array}$ & $B R$ & Yes & 1st & Y: $98.5 \%$ OS: after 20 cycles $Y$ decreased to $78.3 \%$ & [189] \\
\hline $\mathrm{SYO}+\mathrm{EtOH}$ & proROL-PFL & $\begin{array}{l}\text { IA onto microporous resin } \\
\text { NKA (polystyrene) }\end{array}$ & BR & Yes & 1 st & Y: $55.8 \%$ & [189] \\
\hline $\mathrm{SYO}+\mathrm{MeOH}$ & proROL & $\begin{array}{l}\text { CI onto magnetic } \\
\text { chitosan microspheres }\end{array}$ & MSFBR & Yes & 1st & $\begin{array}{l}\text { Y: } 91.3 \% \text { OS: after } 6 \text { reaction cycles } Y \text { decreased } \\
\text { to around } 80 \%\end{array}$ & [190] \\
\hline $\mathrm{SYO}+\mathrm{MeoH}$ & proROL & WCB immobilised into BSPs & BR & Yes & 1st & $\begin{array}{c}\text { Y: over 90\% OS: after } 10 \text { reaction cycles Y } \\
\text { decreased to } 10 \%\end{array}$ & [191] \\
\hline $\mathrm{SYO}+\mathrm{MeoH}$ & proROL & WCB immobilised into BSPs & PBR & Yes & 1st & $\begin{array}{l}\text { Y: over 90\% OS: after } 10 \text { reaction cycles Y } \\
\text { decreased to } 80 \%\end{array}$ & [191] \\
\hline $\mathrm{SO}+\mathrm{EtOH}$ & proROL & $\begin{array}{l}\text { CI onto modified sepiolite with } \\
p \text {-hydroxybenzaldehyde linker } \\
\mathrm{CI} \text { onto modified sepiolite with }\end{array}$ & BR & No & 1st & C: $84.3 \%$ OS: after 9 cycles C decreased to $21.4 \%$ & [192] \\
\hline $\mathrm{SO}+\mathrm{EtOH}$ & proROL & $\begin{array}{l}\text { benzylamine-terephthalic } \\
\text { aldehyde linker }\end{array}$ & BR & No & 1st & & [192] \\
\hline $\mathrm{SO}+\mathrm{EtOH}$ & proROL & IE onto demineralised sepiolite & BR & No & 1 st & $\begin{array}{l}\text { Y: } 90.2 \% \text { OS: proROL IE after } 9 \text { cycles } C \\
\text { decreased to } 18.1 \%\end{array}$ & [192] \\
\hline $\begin{array}{l}\text { Pistacia chinensis bge } \\
\text { seed oil }+\mathrm{MeOH}\end{array}$ & rROL & CI onto Amberlite IRA-93 & BR & Yes & 2nd & Y: $92 \%$ OS: after 8 cycles $Y$ decreased to $60 \%$ & [196] \\
\hline $\begin{array}{l}\text { Pistacia chinensis bge } \\
\text { seed oil + } \mathrm{MeOH}\end{array}$ & rROL & IA microporous resin HPD-400 & BR & Yes & 2nd & Y: $94 \%$ OS: after 8 cycles Y decreased to $50 \%$ & [196] \\
\hline
\end{tabular}


Table 5. Cont

\begin{tabular}{|c|c|c|c|c|c|c|c|}
\hline Substrates & Lipase & Immobilisation Technique & Reactor Type & Stepwise Addition & Biodiesel Generation & $\begin{array}{c}\text { Yield-Conversion/ } \\
\text { Operational Stability }\end{array}$ & Ref. \\
\hline $\begin{array}{l}\text { Calophyllum inophyllum } \\
\text { linn oil + MeOH }\end{array}$ & proROL & WCB immobilised into BSPs & PBR & Yes & 2nd & Y: $92 \%$ OS: after 6 cycles Y decreased a $4.9 \%$ & [197] \\
\hline $\begin{array}{l}\text { Oil extracted from } \\
\text { Nannochloropsis } \\
\text { gaditana }+\mathrm{MeOH}\end{array}$ & proROL & WCB & BR & Yes & 3 rd & Y: $83 \%$ OS: after 3 cycles $Y$ decreased to $71 \%$ & [198] \\
\hline $\begin{array}{l}\text { Oil extracted from } \\
\text { Nannochloropsis gaditana } \\
+\mathrm{MeOH} \\
\text { Oil extracted from }\end{array}$ & proROL & WCB immobilised into BSPs & BR & Yes & 3 rd & Y: $70 \%$ OS: second cycle Y decreased to $43 \%$ & [198] \\
\hline $\begin{array}{c}\text { Nannochloropsis gaditana } \\
+\mathrm{MeOH} \\
\text { Oil extracted from }\end{array}$ & proROL & WCB & TPB & No & $3 \mathrm{rd}$ & Y: $58 \%$ & [200] \\
\hline $\begin{array}{l}\text { Nannochloropsis gaditana } \\
+\mathrm{EtOH}\end{array}$ & proROL & WCB & TPB & No & $3 \mathrm{rd}$ & $Y: 92 \%$ & [200] \\
\hline $\begin{array}{l}\text { Oil extracted from } \\
\text { Botryococcus braunii } \\
+\mathrm{MeOH}\end{array}$ & proROL & WCB & ТРВ & No & 3 rd & Y: $58 \%$ & [200] \\
\hline $\begin{array}{l}\text { Oil extracted from } \\
\text { Botryococcus braunii } \\
+ \text { EtOH }\end{array}$ & proROL & WCB & ТРВ & No & 3 rd & Y: $68 \%$ & [200] \\
\hline $\begin{array}{l}\text { Oil extracted from } \\
\text { Chlorella vulgaris } \\
+\mathrm{MeOH}\end{array}$ & proROL & Free enzyme & BR & Yes & 3 rd & C: $75 \%$ & [201] \\
\hline $\begin{array}{l}\text { Oil extracted from } \\
\text { Chlorella vulgaris } \\
+\mathrm{MeOH}\end{array}$ & proROL & IA onto MNP & BR & Yes & 3 rd & C: $46 \%$ OS: after 5 cycles decreased to $10 \%$ & [201] \\
\hline $\begin{array}{l}\text { Oil extracted from } \\
\text { Chlorella vulgaris } \\
+\mathrm{MeOH}\end{array}$ & proROL & CI onto AP modified MNP & BR & Yes & 3 rd & C: $53 \%$ OS: after 5 cycles C decreased to $25 \%$ & [201] \\
\hline $\begin{array}{l}\text { Oil extracted from } \\
\text { Chlorella vulgaris } \\
+\mathrm{MeOH}\end{array}$ & proROL & CI onto AP-GA modified MNP & BR & Yes & $3 \mathrm{rd}$ & C: $69.8 \%$ OS: after 5 cycles C decreased to $45 \%$ & [201] \\
\hline $\begin{array}{l}\text { Sludge palm oil } \\
+\mathrm{MeOH}\end{array}$ & proROL & $\begin{array}{l}\text { IE into alginate-polyvinyl } \\
\text { alcohol beads }\end{array}$ & BR & No & $3 \mathrm{rd}$ & Y: $91.30 \%$ OS: no activity loss after 15 cycles & [202] \\
\hline $\begin{array}{l}\text { Oil extracted from } \\
\text { SCG }+\mathrm{MeOH}\end{array}$ & $\begin{aligned} & \text { R. delemar } \\
(= & \text { oryzae }) \text { lipase }\end{aligned}$ & Free enzyme & $\mathrm{BR}$ & No & $3 \mathrm{rd}$ & Y: $18 \%$ & [203] \\
\hline $\mathrm{WCO}+\mathrm{MeOH}$ & proROL & Free enzyme & BR & & 3 rd & Y: $93 \%$ & [204] \\
\hline WCO + iso-propanol & proROL & Free enzyme & $\mathrm{BR}$ & & $3 \mathrm{rd}$ & Y: $86.8 \%$ & [204] \\
\hline $\mathrm{WCO}+$ iso-butanol & proROL & Free enzyme & $\mathrm{BR}$ & & 3 rd & $Y: 80.2 \%$ & [204] \\
\hline $\begin{array}{c}\text { WCO + } \\
\text { iso-amyl alcohol }\end{array}$ & proROL & Free enzyme & BR & & $3 \mathrm{rd}$ & $Y: 64 \%$ & [204] \\
\hline $\mathrm{WCO}+\mathrm{MeOH}$ & proROL & WCB IE into calcium alginate beads & BR & & $3 \mathrm{rd}$ & Y: $84 \%$ & [204] \\
\hline
\end{tabular}


Table 5. Cont.

\begin{tabular}{|c|c|c|c|c|c|c|c|}
\hline Substrates & Lipase & Immobilisation Technique & Reactor Type & Stepwise Addition & Biodiesel Generation & $\begin{array}{l}\text { Yield-Conversion/ } \\
\text { Operational Stability }\end{array}$ & Ref. \\
\hline WCO + iso-propanol & proROL & WCB IE into calcium alginate beads & $\mathrm{BR}$ & & 3 rd & Y: $71 \%$ & [204] \\
\hline $\mathrm{WCO}+$ iso-butanol & proROL & WCB IE into calcium alginate beads & BR & & 3 rd & $Y: 62 \%$ & [204] \\
\hline $\begin{array}{c}\text { WCO+ } \\
\text { iso-amyl alcohol }\end{array}$ & proROL & WCB IE into calcium alginate beads & BR & & 3 rd & $Y: 43 \%$ & [204] \\
\hline $\mathrm{JO}+\mathrm{MeOH}$ & proROL & WCB IE into sodium alginate beads & $\mathrm{BR}$ & No & 2nd & Y: $80.5 \%$ OS: after 6 cycles $Y$ decreased to $61.5 \%$ & [205] \\
\hline $\mathrm{KO}+\mathrm{MeOH}$ & proROL & WCB IE into sodium alginate beads & $\mathrm{BR}$ & No & 2nd & Y: $78.3 \%$ OS: after 6 cycles $Y$ decreased to $63.4 \%$ & [205] \\
\hline $\mathrm{SYO}+\mathrm{MeOH}$ & proROL & WCB & BR & Yes & 1 st & Y: $80 \%$ OS: after 3 cycles Y decreased to $18 \%$ & [206] \\
\hline $\mathrm{SYO}+\mathrm{MeOH}$ & proROL & WCB immobilised into BSPs & BR & Yes & 1st & Y: $82 \%$ OS: after 10 cycles $Y$ decreased to $10 \%$ & [206] \\
\hline $\mathrm{SYO}+\mathrm{MeOH}$ & proROL & CI WCB immobilised into BSPs & $B R$ & Yes & 1st & Y: $74 \%$ OS: after 35 cycles $Y$ decreased to $65 \%$ & [206] \\
\hline $\mathrm{SYO}+\mathrm{MeOH}$ & proROL & WCB immobilised into BSPs & $\mathrm{BR}$ & Yes & 1st & Y: $82 \%$ OS: after 6 cycles $Y$ decreased to $48 \%$ & [207] \\
\hline $\mathrm{SYO}+\mathrm{MeOH}$ & proROL & CI WCB immobilised into BSPs & BR & Yes & 1st & Y: $80 \%$ OS: after 6 cycles $Y$ decreased to $70 \%$ & [207] \\
\hline $\mathrm{ALO}+\mathrm{MeOH}$ & rROL & IA onto rice husk & BR & Yes & 2nd & & [208] \\
\hline $\mathrm{ALO}+\mathrm{MeOH}$ & rROL & IA onto ReliZyme ${ }^{\mathrm{TM}}$ OD403 & $B R$ & Yes & 2nd & Y: $64.5 \%$ OS: after 7 cycles $Y$ decreased to $41.3 \%$ & [208] \\
\hline $\begin{array}{l}\text { Crude microbial oil } \\
\text { from Candida sp. } \\
\text { LEB-M3 }+\mathrm{MeOH}\end{array}$ & rROL & IA onto ReliZyme ${ }^{\mathrm{TM}} \mathrm{OD} 403$ & BR & Yes & 3 rd & Y: $38 \%$ OS: after 7 cycles $Y$ decreased to $26.6 \%$ & [209] \\
\hline $\begin{array}{l}\text { Neutralised microbial } \\
\text { oil from Candida sp. } \\
\text { LEB-M3 + } \mathrm{MeOH}\end{array}$ & rROL & IA onto ReliZyme ${ }^{\mathrm{TM}} \mathrm{OD} 403$ & $B R$ & Yes & 3 rd & Y: $38 \%$ & [209] \\
\hline $\mathrm{OO}+\mathrm{MeOH}$ & rROL & IA onto ReliZyme ${ }^{\mathrm{TM}} \mathrm{OD} 403$ & $\mathrm{BR}$ & Yes & 1st & Y: $54.3 \%$ OS: after 7 cycles $Y$ decreased to $40 \%$ & [209] \\
\hline $\mathrm{OA}+\mathrm{MeOH}$ & rROL & IA onto ReliZyme ${ }^{\mathrm{TM}}$ OD403 & BR & Yes & 1st & Y: $68 \%$ & [209] \\
\hline $\mathrm{RO}+\mathrm{EtOH}$ & proROL & IA onto microporous resin NKA & BR & No & 1st & $\begin{array}{c}\mathrm{Y} \text { : above } 98 \% \text { OS: After } 10 \text { cycles } \mathrm{Y} \text { decreased } \\
\text { to } 60 \%\end{array}$ & [210] \\
\hline $\mathrm{JO}+\mathrm{MeOH}$ & proROL-CRL & $\begin{array}{l}\text { WCB (proROL) and free enzyme } \\
\text { (CRL) IE into sodium } \\
\text { alginate beads }\end{array}$ & PBR & No & 2nd & $Y: 84.2 \%$ & [211] \\
\hline $\mathrm{KO}+\mathrm{MeOH}$ & proROL-CRL & $\begin{array}{l}\text { WCB (proROL) and free enzyme } \\
\text { (CRL) IE into sodium } \\
\text { alginate beads }\end{array}$ & PBR & No & 2nd & Y: $81 \%$ & [211] \\
\hline $\mathrm{WCO}+\mathrm{MeOH}$ & proROL & WCB IE into sodium alginate beads & BR & No & 3 rd & Y: $94.01 \%$ & [212] \\
\hline $\mathrm{WCO}+$ Methyl acetate & proROL & WCB IE into sodium alginate beads & $B R$ & No & $3 \mathrm{rd}$ & $Y: 91.11 \%$ & [212] \\
\hline WCO + Ethyl acetate & proROL & WCB IE into sodium alginate beads & $\mathrm{BR}$ & No & $3 r d$ & $Y: 90.06$ & [212] \\
\hline $\mathrm{WCO}+\mathrm{MeOH}$ & proROL & IE into sodium alginate beads & BR & No & $3 \mathrm{rd}$ & Y: $83 \%$ & [212] \\
\hline $\mathrm{WCO}+$ Methyl acetate & proROL & IE into sodium alginate beads & $B R$ & No & 3 rd & Y: $80 \%$ & [212] \\
\hline WCO + Ethyl acetate & proROL & IE into sodium alginate beads & $\mathrm{BR}$ & No & $3 \mathrm{rd}$ & Y: $78 \%$ & [212] \\
\hline $\begin{array}{l}\text { Chlorella vulgaris } \\
+\mathrm{MeOH}\end{array}$ & proROL & IA into MNP & $B R$ & Yes & 3 rd & Y: $45 \%$ OS: after 5 cycles $Y$ decreased to $10 \%$ & [213] \\
\hline $\begin{array}{l}\text { Oil extracted from } \\
\text { Chlorella vulgaris } \\
+\mathrm{MeOH}\end{array}$ & proROL & IA into MGO & BR & Yes & 3 rd & Y: $51 \%$ OS: after 5 cycles $Y$ decreased to $16 \%$ & [213] \\
\hline
\end{tabular}


Table 5. Cont.

\begin{tabular}{|c|c|c|c|c|c|c|c|}
\hline Substrates & Lipase & Immobilisation Technique & Reactor Type & Stepwise Addition & Biodiesel Generation & $\begin{array}{c}\text { Yield-Conversion/ } \\
\text { Operational Stability }\end{array}$ & Ref. \\
\hline $\begin{array}{l}\text { Oil extracted from } \\
\text { Chlorella vulgaris } \\
\quad+\mathrm{MeOH}\end{array}$ & proROL & IA into MGO-AP & BR & Yes & 3rd & Y: $54 \%$ OS: after 5 cycles $Y$ decreased to $25 \%$ & [213] \\
\hline Oil extracted from & & & & & & & \\
\hline $\begin{array}{l}\text { Chlorella vulgaris } \\
+\mathrm{MeOH}\end{array}$ & proROL & CI into MGO-AP-GA & BR & Yes & 3rd & Y: $68 \%$ OS: after 5 cycles Y decreased to $58.77 \%$ & [213] \\
\hline $\begin{array}{l}\text { Cottonseed oil } \\
\quad+\mathrm{MeOH}\end{array}$ & proROL & WCB immobilised into BSPs & BR & Yes & 1 st & Y: $27.9 \%$ & [214] \\
\hline $\begin{array}{l}\text { Rubber seed oil } \\
+\mathrm{MeOHe}\end{array}$ & proROL & Free enzyme & BR & Yes & 2nd & $Y: 31 \%$ & [215] \\
\hline $\begin{array}{l}\text { Rubber seed oil + } \\
\text { Ethyl acetate }\end{array}$ & proROL & Free enzyme & $B R$ & No & 2nd & Y: $33.3 \%$ & \\
\hline $\mathrm{SYO}+\mathrm{MeOH}$ & proROL-CRL & $\begin{array}{c}\text { CI onto silica gel pretreated with } \\
\text { AP and GA }\end{array}$ & BR & Yes & 1st & Y: $99.99 \%$ OS: after 20 cycles Y decreased to $85 \%$ & [216] \\
\hline $\begin{array}{c}\mathrm{RO} \text { deodoriser } \\
\text { distillate }+\mathrm{MeOH}\end{array}$ & proROL & Free enzyme & BR & Yes & 1st & Y: $93.07 \%$ & [217] \\
\hline $\begin{array}{c}\text { RO deodoriser } \\
\text { distillate }+\mathrm{MeOH}\end{array}$ & proROL-CRL & Free enzyme & BR & Yes & 1 st & Y: $98.16 \%$ & [217] \\
\hline $\mathrm{ALO}+\mathrm{MeOH}$ & rROL & $\begin{array}{l}\text { CI onto ET, AP and GA pretreated } \\
\text { ReliZyme }^{\mathrm{TM}} \text { HFA403 }\end{array}$ & BR & Yes & 2nd & Y: $57.16 \%$ OS: after 5 cycles Y decreased a $12.31 \%$ & [181] \\
\hline $\mathrm{ALO}+\mathrm{EtOH}$ & rROL & $\begin{array}{c}\text { CI onto ET, AP and GA pretreated } \\
\text { Relizyme }{ }^{\mathrm{TM}} \text { HFA403 }\end{array}$ & BR & Yes & 2nd & Y: $60.25 \%$ OS: after 7 cycles $Y$ decreased a $11.89 \%$ & [181] \\
\hline Triolein $+\mathrm{MeOH}$ & rROL & Free enzyme & $B R$ & No & 1 st & Y: $71.2 \%$ & [117] \\
\hline Triolein + EtOH & rROL & Free enzyme & BR & No & 1 st & Y: $64.2 \%$ & [117] \\
\hline Triolein $+\mathrm{MeOH}$ & rROL & IA onto RelyZyme ${ }^{\mathrm{TM}} \mathrm{OD} 403 \mathrm{~S}$ & BR & No & 1st & Y: $82.6 \%$ & [117] \\
\hline Triolein + EtOH & rROL & IA onto RelyZyme ${ }^{\mathrm{TM}} \mathrm{OD} 403 \mathrm{~S}$ & BR & No & 1st & Y:100.7\% & [117] \\
\hline $\mathrm{JO}+\mathrm{MeOH}$ & $\mathrm{rROL}$ & IA onto Lewatit VP OC 1600 & $\mathrm{BR}$ & Yes & 2 nd & Y: $61 \%$ OS: after 10 cycles $Y$ decreased a $40 \%$ & [218] \\
\hline $\mathrm{JO}+\mathrm{MeOH}$ & rROL & IA onto Lifetech ${ }^{\mathrm{TM}}$ ECR1030M & BR & Yes & 2nd & Y: $63 \%$ OS: after 10 cycles $Y$ decreased a $40 \%$ & [218] \\
\hline $\mathrm{JO}+\mathrm{MeOH}$ & rROL & IA onto Lifetech" ${ }^{\mathrm{TM}} \mathrm{AP} 1090 \mathrm{M}$ & BR & Yes & 2nd & Y: $55 \%$ OS: after 10 cycles $Y$ decreased a $25 \%$ & [218] \\
\hline $\mathrm{JO}+\mathrm{MeOH}$ & rROL & CI onto Lifetech ${ }^{\mathrm{TM}}$ ECR8285M & BR & Yes & 2nd & Y: $63 \%$ OS: after 10 cycles $Y$ decreased a $60 \%$ & [218] \\
\hline $\mathrm{JO}+\mathrm{MeOH}$ & rROL & CI onto Amberlita IRA 96 & BR & Yes & 2nd & Y: $68 \%$ OS: after 10 cycles $Y$ decreased a $20 \%$ & [218] \\
\hline $\mathrm{OO}+\mathrm{MeOH}$ & prorROL & IA onto Amberlite XAD 761 & BR & No & 1st & Y: $77 \%$ & [219] \\
\hline $\mathrm{OO}+\mathrm{EtOH}$ & prorROL & IA onto Amberlite XAD 761 & BR & No & 1 st & Y: $62 \%$ & [219] \\
\hline $\mathrm{OO}+$ Propanol & prorROL & IA onto Amberlite XAD 761 & BR & No & 1 st & Y: $46 \%$ & [219] \\
\hline $\mathrm{OO}+$ Butanol & prorROL & IA onto Amberlite XAD 761 & BR & No & 1 st & Y: $18 \%$ & [219] \\
\hline $\mathrm{SYO}+\mathrm{MeOH}$ & prorROL & IA onto Amberlite XAD 761 & BR & No & 1st & Y: $50 \%$ & [219] \\
\hline $\mathrm{SYO}+\mathrm{EtOH}$ & prorROL & IA onto Amberlite XAD 761 & BR & No & 1st & Y: $46 \%$ & [219] \\
\hline SYO + Propanol & prorROL & IA onto Amberlite XAD 761 & $\mathrm{BR}$ & No & 1st & Y: $35 \%$ & [219] \\
\hline SYO + Butanol & prorROL & IA onto Amberlite XAD 761 & BR & No & 1 st & Y: $10 \%$ & [219] \\
\hline $\mathrm{CO}+\mathrm{MeOH}$ & prorROL & IA onto Amberlite XAD 761 & BR & No & 1 st & Y: $70 \%$ & [219] \\
\hline $\mathrm{CO}+\mathrm{EtOH}$ & prorROL & IA onto Amberlite XAD 761 & $\mathrm{BR}$ & No & 1st & Y: $56 \%$ & [219] \\
\hline $\mathrm{CO}+$ Propanol & prorROL & IA onto Amberlite XAD 761 & BR & No & 1 st & Y: $43 \%$ & [219] \\
\hline $\mathrm{CO}+$ Butanol & prorROL & IA onto Amberlite XAD 761 & BR & No & 1 st & Y: $16 \%$ & [219] \\
\hline $\mathrm{SO}+\mathrm{MeOH}$ & prorROL & IA onto Amberlite XAD 761 & $B R$ & No & 1 st & $Y: 32 \%$ & [219] \\
\hline
\end{tabular}


Table 5. Cont.

\begin{tabular}{|c|c|c|c|c|c|c|c|}
\hline Substrates & Lipase & Immobilisation Technique & Reactor Type & Stepwise Addition & Biodiesel Generation & $\begin{array}{c}\text { Yield-Conversion/ } \\
\text { Operational Stability }\end{array}$ & Ref. \\
\hline $\mathrm{SO}+\mathrm{EtOH}$ & prorROL & IA onto Amberlite XAD 761 & $\mathrm{BR}$ & No & 1 st & $Y: 28 \%$ & [219] \\
\hline SO + Propanol & prorROL & IA onto Amberlite XAD 761 & $\mathrm{BR}$ & No & 1st & Y: $17 \%$ & [219] \\
\hline $\mathrm{SO}+\mathrm{Butanol}$ & prorROL & IA onto Amberlite XAD 761 & $\mathrm{BR}$ & No & 1st & $Y: 7 \%$ & [219] \\
\hline Algal oil $+\mathrm{MeOH}$ & prorROL & IA onto Amberlite XAD 761 & $\mathrm{BR}$ & No & 3rd & Y: $63 \%$ & [219] \\
\hline Algal oil + EtOH & prorROL & IA onto Amberlite XAD 761 & $B R$ & No & $3 \mathrm{rd}$ & Y: $55 \%$ & [219] \\
\hline Algal oil + Propanol & prorROL & IA onto Amberlite XAD 761 & $\mathrm{BR}$ & No & $3 \mathrm{rd}$ & Y: $40 \%$ & [219] \\
\hline Algal oil + Butanol & prorROL & IA onto Amberlite XAD 761 & $B R$ & No & $3 \mathrm{rd}$ & Y: $13 \%$ & [219] \\
\hline $\mathrm{ALO}+\mathrm{MeOH}$ & rROL & $\begin{array}{l}\text { CI onto AP and GA treated } \\
\text { ReliZyme }^{\mathrm{TM}} \mathrm{HFA403}\end{array}$ & BR & Yes & 2nd & Y: $28.62 \%$ OS: after 9 cycles, Y decreased a $43 \%$ & [170] \\
\hline $\mathrm{JO}+\mathrm{MeOH}$ & proROL & WCB immobilised into BSPs & $\mathrm{BR}$ & Yes & 2nd & Y: $88.6 \%$ OS: after 6 cycles Y decreased a $21 \%$ & [220] \\
\hline $\mathrm{OA}+\mathrm{MeOH}$ & proROL & WCB immobilised into BSPs & $\mathrm{BR}$ & No & 1 st & Y: $80 \%$ OS: after 8 cycles, almost no activity loss. & [221] \\
\hline Rice bran oil + MeOH & proROL & IA onto rod-like mesoporous silica & $\mathrm{BR}$ & No & 1st & Y: $81.7 \%$ OS: after 3 cycles $Y$ decreased to $67.7 \%$ & [222] \\
\hline $\mathrm{JO}+\mathrm{MeOH}$ & proROL & $\begin{array}{l}\text { IE into polyvinyl } \\
\text { alcohol—alginate matrix }\end{array}$ & BR & No & 2nd & Yield: $87.1 \%$ & [223] \\
\hline $\mathrm{ALO}+\mathrm{MeOH}$ & rROL & IA Octadecyl-Sepabeads & BR & Yes & 2nd & $\begin{array}{c}\text { Y: } 58.31 \% \text { OS: after } 2 \text { cycles } Y \text { decreased } \\
\text { to } 54.67 \%\end{array}$ & [224] \\
\hline Tung oil + MeOH & proROL & CI onto Amberlite IRA 93 & $B R$ & Yes & 2nd & Y: $91.9 \%$ OS: after 6 cycles $Y$ decreased to $85.1 \%$ & [95] \\
\hline Babassu oil + EtOH & proROL & WCB immobilised into BSPs & $\mathrm{BR}$ & No & 1 st & Y: $74.15 \%$ & [225] \\
\hline
\end{tabular}


Regarding the third-generation biodiesel, microalgae and waste oils have been the most studied substrates. The former has several advantages that make the overall process of biodiesel production more environmentally friendly as microalgae oil production involves atmospheric $\mathrm{CO}_{2}$ fixation and can use domestic wastewater like growth substrate facilitating its posterior treatment. However, the main drawbacks for microalgae oil employment are the scale-up of photobioreactors and lipids extraction [226,227]. Nevertheless, ROL has been satisfactorily employed with this substrate, for instance, with oils extracted from Nannochloropsis gaditana [198-200], Botryococcus braunii [200] and Chlorella vulgaris [201]. Actually, with the last one, fatty acid methyl esters (FAME) conversions over $70 \%$ were obtained indicating ROL suitability for biodiesel production with microalgae oil. Additionally, oils extracted from oleaginous yeasts, such as Candida sp. LEB-M3, have been also employed. The use of yeasts becomes important in biodiesel refineries as they might grow in the glycerol coming from this biofuel production [209]. Regarding waste oils, they have a significant potential in biodiesel industry because of their relevance in circular economy strategies which aim to avoid residue generation by seeking new applications to waste $[228,229]$. Moreover, considering the tight economic competition between biodiesel and fossil fuels, cheap raw materials are required. In fact, the cost of the feedstocks is more than the $70 \%$ of the total cost of biodiesel. Thus, oleaginous wastes might help lowering these percentage and making enzymatic biodiesel production feasible [230]. Sludge from palm oil [202] and spent coffee grounds [203] can be found amongst some of the oleaginous residues studied in biodiesel production with ROL. However, waste cooking oil is the foremost substrate of this category because it is inexpensive and, through its employment in biodiesel synthesis, public institutions avoid the great cost of its management [231,232]. Relevant results have been published with WCO, for instance, Bharathiraja et al. [204] reported maximum triglyceride conversion of $94 \%$. Nevertheless, not many studies dealing with ROL and WCO have been published and, considering the great relevance of this substrate for biodiesel industry, it could be a possible research target for future projects.

Biocatalysts operational stability, reusability and price are related and essential traits that must be considered in enzymatic biodiesel production because of the high cost of enzymes and the tight economic competition with conventional diesel. Some approaches have focused on cutting prices of the enzymes through heterologous production, as it has been explained in the previous section. Besides, other strategies have centred on lipase immobilisation. This technique allows enzyme reutilisation and generally enhances enzyme stability $[6,233,234]$. In the following paragraphs, the different immobilisation strategies assessed with ROL in biodiesel production will be introduced.

Earlier attempts of employing this enzyme in biodiesel synthesis were principally based on whole-cell biocatalysts (WCBs). Thus, the enzyme acts confined in its natural cellular environment, which protects the lipase from inactivation and degradation. Moreover, as no downstream processes of the biocatalyst are needed, its final cost is considerably lowered [235]. Syed et al. [205] immobilised lipase-producing $R$. oryzae cells into alginate beads and employed them in biodiesel production with jatropha and karanja oil. A response surface optimisation was applied and under the best conditions, biodiesel yields of $73.5 \%$ and $72.5 \%$ with each respective oil were obtained. In addition, operational stability of the biocatalyst was evaluated and after six cycles, just an activity loss of $20 \%$ was reported. Even if free cells, without immobilisation into alginate beads, could have been used in biodiesel production, Sun et al. [206] stated the suitability of cell immobilisation to avoid enzyme leakage and denaturation. This author immobilised R. oryzae fungus cells onto biomass support particles (BSPs) and obtained higher operational stability than using free cells. Moreover, to further minimise the enzyme leakage and deactivation, the crosslinking agent glutaraldehyde was used for immobilised cells treatment. The crosslinked biocatalyst obtained better FAMEs yields and operational stability. In the same sense, glutaraldehyde treatment of WCBs—also called WCBs stabilisation-was reported by Ban et al. [207] as well. Lately, He et al. [188] employed this strategy too and obtained a ROL biocatalyst with increased operational stability. After six reactions cycles, more than $90 \%$ of initial activity was maintained. However, WCBs show higher complexity in being reused and worse conversion rates than free lipases immobilised onto acrylic resins [235]. For instance, Bharathiraja et al. [204] published that 
WCBs exhibit worse reaction rate than immobilised purified proROL because of diffusional problems. Therefore, considering these inconveniences and how heterologous production of ROL has been improved, the use of free ROL and its subsequent immobilisation have gained importance amongst the published works.

Traditionally, lipases have been immobilised through adsorption, particularly onto hydrophobic supports-generally acrylic resins with hydrophobic superficial groups such as octadecyl or divinylbenzene-because of the presence of a large hydrophobic patch around the catalytic triad of the lipases that enables an easy immobilisation and might lead to their hyperactivation [236,237]. However, during biodiesel enzymatic synthesis, highly non-polar reaction mediums are employed that might cause enzyme desorption and in consequence, poor biocatalyst operational stability [84]. Nevertheless, some authors have used ROL with this immobilisation technique and obtained outstanding stability results. For instance, Bonet-Ragel et al. [208] reported that after six consecutive reaction cycles, the biocatalysts retained more than the $60 \%$ of the initial activity, in accordance with the results published by Duarte et al. [209] and Su et al. [210]. Moreover, in order to overcome the potential enzyme leakage when adsorption techniques are used, some published works have treated the obtained biocatalysts with crosslinking agents like glutaraldehyde, as it was previously explained for WCBs [196,238]. Notwithstanding these mentioned works and other listed in Table 5, ROL entrapment and covalent immobilisation are the most common immobilisation techniques. The former has been used not only with free ROL but with WCBs because it is an easy, fast and cheap immobilisation technique [239]. The most common entrapment strategies are based on polyvinyl alcohol and alginate employment [211,212,223,240]. Muanruksa et al. [202] obtained outstanding results with free proROL immobilised into alginate-polyvinyl alcohol beads. Esterification degrees over $90 \%$ were reported and the biocatalyst exhibited a high operational stability, 15 reaction cycles were done with almost no loss of activity.

Regarding covalent immobilisation, since the binding forces between the lipase and the supports are strong, obtained biocatalysts tend to show high stability, high resistance to extreme $\mathrm{pH}$ and temperature conditions and almost no enzyme leakage. However, these strong links between the enzyme and the support, as well as the harsh conditions employed during immobilisation process, might have a negative impact on the enzyme activity [241-243]. In any case, there are several studies that employ this immobilisation technique in biodiesel synthesis. Nematian et al. [213] immobilised proROL onto a superparamagnetic nanostructure and described that amongst the three different biocatalysts studied-two based on lipase-support electrostatic interactions and the third one on covalent-linkage- the covalently immobilised proROL showed higher conversion and operational stability. Bonet-Ragel et al. [181] covalently immobilised rROL onto glutaraldehyde pre-treated epoxide acrylic resins and studied its reaction performance and operational stability in biodiesel synthesis with methanol and ethanol as acyl-acceptors. Under the best conditions, yields close to the theoretical $100 \%$ were obtained after $360 \mathrm{~min}$ for methanol and $260 \mathrm{~min}$ for ethanol. In addition, regarding operational stability, no significant activity loss was observed after five consecutive reaction cycles with both alcohols. Besides, Luna et al. [192] described similar operational stability results with ethanol and sunflower oil as substrates, indicating that covalent immobilisation is an adequate technique for biodiesel synthesis with ROL.

In terms of operational strategy in biodiesel synthesis, although ROL has been described as a suitable industrial and solvent-tolerant enzyme, some improvements have been reported to obtain better reaction yields, higher stability or enhance the scale-up of the bioprocess. One of the most commonly employed approach is based on the stepwise addition of the alcohol as the interaction between the lipase and the alcohol is the main enzyme-deactivating factor [244,245]. Several authors have published works in which ROL and stepwise addition strategy have been employed [181,214]. Additionally, other authors have focused on seeking the most adequate acyl-acceptor-the one that has fewer negative effect on the enzyme-by testing different alcohols $[204,240]$ and even the short-esters of the corresponding alcohols performing interesterification reactions [212,215]. Besides, 
regarding solvents employment, their absence in solvent-free systems has arisen as an interesting operational alternative because of the minimisation of biodiesel downstream processes and the avoidance of hazardous solvents, making the overall biotransformations more cost-effective and environmentally friendly $[170,208,215,218]$.

Lately, the joint employment of both 1,3-regiospecific and non-specific lipases have been researched in order to accelerate biodiesel reaction rates and obtain higher yields [187]. Lee et al. [216] reported yields close to $100 \%$ in 2-h reaction and outstanding operational stabilities when using proROL and Candida rugosa lipase (CRL). Actually, the conversion yield was still $85 \%$ after 20 reaction cycles. In line with these results, Zeng et al. [217] described higher biodiesel production rates when employing together proROL and CRL.

Regarding the scale-up of biodiesel production using ROL, Canet et al. [185] compared packed bed reactor (PBR) with stirred tank reactor (STR) in biodiesel synthesis with rROL immobilised through hydrophobic adsorption. Results showed a higher reaction rate with STR than PBR but, just the opposite outcome when operational stability was the analysed trait. Other authors have also employed PBRs $[191,197,211]$ or even more genuine reactors such as the magnetically stabilised fluidised bed reactor [190] or three-phase bioreactors [186]. However, there are not many works related to the scale-up of biodiesel production with ROL considering the vast amount of research papers published dealing with this biocatalyst. Therefore, more research in this field could be relevant for future projects.

\subsection{Structured Lipids Production}

Fats and oils are consumed in daily diets as an important source of energy, essential fatty acids and fat-soluble nutrients. Their functional, nutritional and organoleptic properties depend on their composition in saturated and polyunsaturated fatty acids, fatty acid chain length and on the distribution of the different fatty acids in the triacylglycerols (TAGs) (position sn-1, sn-3 or sn-2). Therefore, by modifying the fatty acids composition or its profile, lipids with improved properties might be obtained, the so-called structured lipids (SL). Currently, there are various SLs of commercial interest whose properties have been widely described (Table 6), (i) low caloric and dietetic triacylglycerols that include TAGs with medium-chains (MMM) and TAGs with short- and medium-chain fatty acids in $s n-1$ and $s n-3$ and a long-chain fatty acids in $s n-2$ position, SLS and MLM respectively; (ii) human milk fat substitutes (HMFS), (iii) cocoa butter equivalents (CBE), (iv) trans- free plastic fats, (v) triacylglycerols rich in specific long-chain and polyunsaturated fatty acids (PUFAs) and recently, even (vi) diacylglycerols (DAG) and monoacylglycerols (MAG) have been considered as SLs [246,247]. 
Table 6. Definition and properties of the main commercially relevant structured lipids.

\begin{tabular}{|c|c|c|c|}
\hline SL Type & Definition & Properties & Ref. \\
\hline Low caloric and dietetic TAGs & $\begin{array}{l}\text { Present lower caloric value than } \\
\text { conventional oils and fats. } \\
\text { - } \quad \text { Include SLS-, MLM- and MMM- type TAGs. }\end{array}$ & $\begin{array}{l}\text { - } \quad \mathrm{M} \text { and } \mathrm{S} \text { fatty acids present lower caloric value than } \\
\text { their counterparts } \mathrm{L} \text {. } \\
\text { - } \mathrm{M} \text { fatty acids have lower tendency to } \\
\text { get accumulated. } \\
\text { - Released } \mathrm{M} \text { fatty acids can be directly absorbed and } \\
\text { provide readily energy in the liver. }\end{array}$ & [246-249] \\
\hline Human milk fat substitutes (HMFS) & $\begin{array}{l}\text { - Mimic the fatty acid profile of human milk. } \\
\text { - Contain oleic ( }(30-35 \%) \text {, palmitic }(20-30 \%) \text {, } \\
\text { linoleic (7-14\%) and stearic acids (5.7-8\%). } \\
\text { - Palmitic acid mainly in } s n-2 \text { position. }\end{array}$ & $\begin{array}{l}\text { - Promote palmitic acid absorption } \\
\text { as 2-monoacylpalmitate } \\
\text { - Promote calcium absorption }\end{array}$ & {$[246,247,250,251]$} \\
\hline Cocoa butter equivalents (CBE) & $\begin{array}{l}\text { - Mimic the scarce natural cocoa butter } \\
\text { Mainly formed by saturated fatty acids } \\
\text { (stearic and palmitic acids) in } s n-1,3 \text { and } \\
\text { monounsaturated fatty acids (oleic acid) in } \\
s n-2 \text { position. }\end{array}$ & $\begin{array}{l}\text { - } \quad \text { Desirable polymorph is } \beta \text { form } \\
\text { - Similar organoleptic properties to cocoa butter }\end{array}$ & {$[246,247,252,253]$} \\
\hline Trans-free plastic fats & $\begin{array}{l}\text { Mimic trans fatty acids containing } \\
\text { hydrogenated vegetable oils. }\end{array}$ & $\begin{array}{l}\text { - Avoid potential cardiovascular diseases caused by } \\
\text { trans fatty acids. }\end{array}$ & {$[247,254,255]$} \\
\hline $\begin{array}{l}\text { TAGs rich in specific long-chain and } \\
\text { polyunsaturated fatty acids (PUFAs) }\end{array}$ & $\begin{array}{l}\text { - Modified TAGs containing a combination of } \\
\mathrm{n}-3 \text { and n-6 PUFAs to enhance } \\
\text { nutritional values. } \\
\text { - Mainly eicosapentaenoic (EPA) and } \\
\text { docosahexaenoic acid (DHA) are employed. }\end{array}$ & $\begin{array}{l}\text { - EPA decreases blood viscosity, platelets aggregation } \\
\text { and promotes vasodilation. } \\
\text { - DHA promotes sensorial and neuronal maturation } \\
\text { in babies. }\end{array}$ & {$[246,256]$} \\
\hline MAGs and DAGs & $\begin{array}{l}\text { - Modified lipids containing one or two fatty } \\
\text { acids linked to a glycerol }\end{array}$ & $\begin{array}{l}\text { - Non-ionic surfactants capable of using as emulsifiers } \\
\text { in the food industry. } \\
\text { 1,3-DAGs reduce serum TAGs level and supress } \\
\text { body fat accumulation }\end{array}$ & {$[182,184,247,257]$} \\
\hline
\end{tabular}


SLs production can be carried out through chemical or enzymatical processes, the latter having several advantages when compared to chemical catalysis [258]. Hence, in the same way as stated for biodiesel synthesis in the previous section, enzymatically catalysed reactions allow milder reaction conditions which in this case, as well as lowering energy consumption, might lead to a reduction in the loss of original attributes of temperature-sensitive substrates and products. Moreover, through enzymatic catalysis, the use of deleterious solvents can be avoided enabling a safer and more environmentally friendly food production. However, the most remarkable advantage of lipase employment in this biotransformation is their specificity and selectivity $[259,260]$. Concretely, 1,3-regiospecific lipases like ROL arise a keen interest because of their capacity to only modify the $s n-1$ and $s n-3$ positions of TAGs-even though acyl-migration phenomena might occur depending on reaction conditions.

Table 7 shows a summary of the latest published works about SLs synthesis employing ROL. Nunes et al. [261] produced MLM-type SLs by acidolysis of olive oil with capric and caprylic acids. The employed biocatalysts were rROL produced in K. phaffii and commercial native ROL (proROL), both of them covalently immobilised onto Eupergit $(C)$ and modified Sepiolite. Noticeably, rROL showed a better performance than the native lipase, the percentages of incorporated capric and caprylic acids were higher as well as the operational stability. In spite of the use of pure or commercial substrates, oleaginous wastes or even non-commercially profitable oils might also be employed for MLM-type SLs synthesis with ROL. For instance, Mota et al. [262] described how low-calorie SLs of MLM-type can be produced using oil extracted from spent coffee grounds and oil from olive pomace with proROL immobilised onto magnetic nanoparticles. In the same line, Costa et al. [263] synthesised MLM-type SLs with the oil extracted from grapeseeds of Vitis vinifera L., which are a by-product of the wine industry. Moreover, instead of residual oils, Nagao et al. [264] employed the oil from the oleaginous microorganism Mortierella alpina to produce MLMs rich in arachidonic acid, a precursor of several hormones. 
Table 7. Summary of structured lipids production with Rhizopus oryzae lipase as main biotcatalyst.

\begin{tabular}{|c|c|c|c|c|c|c|}
\hline Product & Substrates & Reaction Type & Lipase & Immobilisation Technique & ID/OS & Ref. \\
\hline MLM & $\mathrm{OO}+\mathrm{CRA}$ & Acidolysis & proROL/rROL & 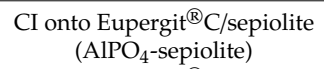 & ID: $21.6 \%$. OS: half-life $159 \mathrm{~h}$ & [261] \\
\hline MLM & $\mathrm{OO}+\mathrm{CA}$ & Acidolysis & proROL/rROL & $\begin{array}{c}\mathrm{CI} \text { onto Eupergit }{ }^{\circledR} \mathrm{C} / \text { sepiolite } \\
\left(\mathrm{AlPO}_{4} \text {-sepiolite) }\right.\end{array}$ & ID: $34.82 \%$. OS: half-life $136 \mathrm{~h}$ & [261] \\
\hline MLM & $\mathrm{SCG}+\mathrm{CA}$ & Acidolysis & proROL & CI onto GA treated MNP & ID: $50 \%$ & [262] \\
\hline MLM & SCG + ethyl caprate & Interesterification & proROL & CI onto GA treated MNP & ID: $26 \%$ & [262] \\
\hline MLM & $\mathrm{OP}+\mathrm{CA}$ & Acidolysis & proROL & $\mathrm{CI}$ onto GA treated MNP & ID: $51 \%$ OS: 6.8 batches & [262] \\
\hline MLM & OP + ethyl caprate & Interesterification & proROL & CI onto GA treated MNP & ID: $46 \%$. OS: 9.1 batches & [262] \\
\hline MLM & Grapeseed oil + CRA & Acidolysis & rROL & CI onto Amberlite IRA 96 & ID: $54 \%$. OS: half-life $166 \mathrm{~h}$ & [263] \\
\hline MLM & Grapeseed oil + CA & Acidolysis & rROL & CI onto Amberlite IRA 96 & ID: $69 \%$ OS: half-life $118 \mathrm{~h}$ & [263] \\
\hline MLM & TGA58F + CA & Acidolysis & proROL & IA onto Dowex WBA & ID: $64.6 \%$ & [264] \\
\hline MLM & $\mathrm{TGA} 40+\mathrm{CA}$ & Acidolysis & proROL & IA onto Dowex WBA & ID: $62.8 \%$ & [264] \\
\hline MLM & TGA55E + CA & Acidolysis & proROL & IA onto Dowex WBA & $\begin{array}{c}\text { ID: 64.8\% OS: } 90 \text { days in PBR }{ }^{1} \\
\text { dropped } 10 \%\end{array}$ & [264] \\
\hline MLM & $\mathrm{OO}+\mathrm{CRA}$ & Acidolysis & rROL & $\begin{array}{c}\text { CI onto Eupergit }{ }^{\circledR} \text { C/IA onto } \\
\text { Lewatit VP OC } 1600\end{array}$ & $\begin{array}{c}\text { OS: half time } 2.4 \text { batches }(54.3 \mathrm{~h}) \\
\text { with Eupergit }{ }^{\circledR} \mathrm{C}\end{array}$ & [265] \\
\hline MLM & $\mathrm{OO}+\mathrm{CA}$ & Acidolysis & rROL & $\begin{array}{c}\text { CI onto Eupergit }{ }^{\circledR} \text { C/IA onto } \\
\text { Lewatit VP OC } 1600\end{array}$ & $\begin{array}{l}\text { OS: half time } 10.2 \text { batches ( } 234 \mathrm{~h} \text { ) } \\
\text { with Lewatit VP OC } 1600\end{array}$ & [265] \\
\hline MLM & $\mathrm{OO}+\mathrm{CRA}$ & Acidolysis & rROL & CI onto Eupergit ${ }^{\circledR} \mathrm{C}$ & ID: $15.5 \%$ & [266] \\
\hline MLM & $\mathrm{OO}+\mathrm{CA}$ & Acidolysis & rROL & $\mathrm{CI}$ onto Eupergit ${ }^{\circledR} \mathrm{C}$ & ID: $33.3 \%$ & [266] \\
\hline MLM & $\mathrm{OO}+\mathrm{CRA}$ & Acidolysis & rROL & CI onto Amberlite IRA 96 & ID: 76.9 & [267] \\
\hline MLM & $\mathrm{OO}+\mathrm{CA}$ & Acidolysis & rROL & CI onto Amberlite IRA 96 & ID: $85.6 \%$ & [267] \\
\hline HMFS & $\begin{array}{l}\text { PA enriched TAGs + OA } \\
\text { enriched mixtures }\end{array}$ & Acidolysis & proROL & IA onto Accurel ${ }^{\circledR}$ MP-1000 & $\begin{array}{c}\text { ID: OA in } s n-1,367.2 \% \text { - PA in } s n-2 \\
67.8 \% . \text { OS: no activity loss in } \\
10 \text { uses }(190 \mathrm{~h})\end{array}$ & [268] \\
\hline HMFS & Lard + FFA from EPAX 1050TG & Acidolysis & rROL & CI onto Accurel ${ }^{\circledR}$ MP-1000 & $\begin{array}{l}\text { ID: } 24 \mathrm{~mol} \% \text {. OS: after } 4 \text { batches, } \\
55 \% \text { of original activity }\end{array}$ & [269] \\
\hline HMFS & Tripalmitin + FFA from camelina oil & Acidolysis & rROL & $\begin{array}{c}\text { AI onto Relizyme }{ }^{\mathrm{TM}} \\
\text { OD403/S/CI onto Lewatit VP } \\
\text { OC } 1600\end{array}$ & ID: 52\% & [270] \\
\hline \multirow[t]{2}{*}{ TAGs rich in PUFAs } & cod liver + tuna oil + ethanol. & Alcoholysis & proROL & IA onto Accurel ${ }^{\circledR}$ MP-1000 & \multirow{2}{*}{$\begin{array}{c}\text { Alcoholysis ID: } 72 \% \text { OS: } \\
\text { after } 6 \text { cycles, complete deactivation. } \\
\text { ID: } 95 \% \text {. OS: after } 5 \text { cycles, } \\
\text { no activity loss. }\end{array}$} & [271] \\
\hline & 2-MAG from alcoholysis + CRA & Esterification & proROL & IA onto Accurel ${ }^{\circledR}$ MP-1000 & & {$[271]$} \\
\hline TAGs rich in PUFAs & Tuna oil + CRA & Acidolysis & proROL & IA onto Accurel ${ }^{\circledR}$ MP-1000 & \multirow{3}{*}{$\begin{array}{c}\text { OS: over one week } \\
\text { Alcoholysis Y: } 78 \% \text {. OS: } \\
\text { after } 3 \text { cycles, a } 57 \% \text { decrease } \\
\text { Alcoholysis Y: } 78 \% \text {. OS: } \\
\text { after } 3 \text { cycles, no activity decrease }\end{array}$} & [272] \\
\hline \multirow{3}{*}{ TAGs rich in PUFAs } & cod liver oil + ethanol 96\% & Alcoholysis & proROL & IA onto Accurel ${ }^{\circledR}$ MP-1000 & & [273] \\
\hline & cod liver oil + 1-butanol & Alcoholysis & proROL & IA onto Accurel ${ }^{\circledR}$ MP-1000 & & [273] \\
\hline & $\begin{array}{l}\text { Esterification: 2-MAG from } \\
\text { alcoholysis + CRA }\end{array}$ & Esterification & proROL & IA onto Accurel ${ }^{\circledR}$ MP-1000 & Esterification Y: 71\%. & [273] \\
\hline TAGs rich in PUFAs & Fish oil + CRA & Acidolysis & proROL & Non-immobilised & \multirow{3}{*}{$\begin{array}{c}\text { ID: } 2.5 \% \\
\text { ID: } 8.14 \% . \text { OS: after } 10 \text { batches, } \\
\text { no activity loss }\end{array}$} & [274] \\
\hline HMFS & Milkfat + SYO & Interesterification & proROL & EI into polysiloxane-PVA & & [275] \\
\hline CBE & $\mathrm{SO}+\mathrm{SA}-\mathrm{PA}$ mixtures & Acidolysis & proROL & IA onto Accurel ${ }^{\circledR}$ MP-1000 & & [276] \\
\hline
\end{tabular}


Regarding HMFS, Esteban et al. [268] used several commercial lipases, amongst them proROL immobilised onto Accurel ${ }^{\circledR}$ MP-1000, to produce a TAG rich in palmitic acid in sn-2 and oleic acid in $s n-1,3$; the so called OPO, which is the main component of human milk TAGs. proROL showed the best performance in oleic acid incorporation and exhibited a high operational stability, after ten reuse cycles almost no activity loss was found. Simões et al. [269] also tested different lipases for HMFS production and reported that rROL immobilised onto Accurel ${ }^{\circledR}$ MP-1000 showed a similar performance to Novozymes 435 and Lipozyme RM IM in acidolysis reaction between lard and FFA mixture from fish oil rich in docosahexaenoic acid. Besides, Faustino et al. [270] immobilised rROL produced in K. phaffii onto two different supports, Lewatit VP OC 1600 and Relizyme OD403/S, and applied the formed biocatalysts in the production of HMFS rich in polyunsaturated fatty acids (PUFAs). The acidolysis reaction was carried out in solvent-free system between tripalmitin and FFAs (mainly linoleic and linolenic acids) from camelina oil, which proved to be a good source of PUFAs. According to the authors, the results obtained with rROL immobilised onto Lewatit VP OC 1600 were comparable to the commonly used commercial lipase Lipozyme RM IM.

Triacylglycerols rich in long-chain and polyunsaturated fatty acids have also been produced with ROL. In most of the cases, these SLs' production is based on a two-step process in order to minimise the acyl migration phenomena [277]. In the first step, through alcoholysis reaction, 2-monoacylglycerols (2-MAGs) are obtained from oils containing TAGs rich in PUFAs or long-chain fatty acids in the mentioned $s n-2$ position, usually fish oils. Then, these 2-MAGs are esterified with other relevant FFA to obtain the nutritionally interesting TAGs rich in PUFAs. For instance, Muñio et al. [271] studied the performance of different commercial lipases, including proROL immobilised onto Accurel ${ }^{\circledR}$ MP-1000, in the process of alcoholysis of tuna and cod oil to obtain 2-MAGs and then, carry out their subsequent esterification with capric acid. In alcoholysis reaction the commercial lipase Novozyme 435 showed a better operational stability than Lipase D (commercial proROL), although the latter exhibited higher reaction yield. During esterification reaction, Lipase D obtained the highest SLs percentage (over 90\%) in the mixture. Moreover, no loss in proROL activity was observed after at least five reaction cycles. Hita et al. [272] and Rodriguez et al. [273] reported similar results with immobilised proROL.

With respect to CBE, although Ray et al. [276] described the kinetics of the acidolysis of high oleic sunflower oil with stearic-palmitic acid mixtures that, after further fractionation of the product, could be potentially used in CBE formulations, ROL has not been extensively used for CBE production. Therefore, this subject might be a great research target for future projects, as well as DAG and MAG synthesis, which have not been specifically treated but just as a minor topic during other products synthesis, like biodiesel.

\subsection{Flavour Esters Production}

Flavour and aromatic esters are widely found in nature and have pleasant organoleptic attributes, including fruity, floral, spicy, creamy or nutty aromas. These traits made them suitable as ingredients for food, beverages, cosmetics, pharmaceuticals, chemicals and personal care products, like perfumes, body lotions, shampoos and other toiletries $[278,279]$. In general, most of the flavour and fragrance compounds are produced through extraction from their natural source, usually fruits, plants and flowers. However, they are found in the environment in low concentrations making the extraction a costly process and not viable to fulfil their growing demand. Therefore, chemical and enzymatic synthesis procedures have arisen to solve flavour esters scarcity $[280,281]$. Noticeably, the latter exhibits a significant advantage-notwithstanding the already explained benefits of enzymatic synthesis over chemical one in the previous sections-which is the capacity to label the obtained products as natural according to European Legislation (EC 1334/2008) if and when the employed reactants are also natural. Thereby, the use of enzymes satisfies consumers trend towards natural products and boosts economic value of the obtained flavour esters [278]. In fact, as well as ROL, other lipases have been used for flavour esters production, for instance, the commercial Novozym ${ }^{\circledR} 435$ (Candida antartica lipase B) [280,281], Candida rugosa lipase [282,283] and Burkholderia cepacia lipase [284]. 
Ethyl butyrate is an important component of many fruit flavours such as pineapple, passion fruit and strawberry [285]. The enzymatic synthesis of this compound can be carried out through esterification of butyric acid and ethanol. Guillen et al. [286] immobilised rROL onto three different supports, EP100, Eupergit ${ }^{\circledR} \mathrm{CM}$ and Octadecyl-Sepabeads to test them in this esterification reaction. In terms of reaction rate and yield, rROL immobilised onto EP100 supports showed the best performance. However, rROL immobilised onto Octadecyl-Sepabeads exhibited the highest operational stability. Consequently, this biocatalyst was used for further research in which the effects of butyric acid and ethanol concentration were studied through DoE strategy to maximise the reaction rate and final yield [287]. The obtained results indicated that the suitable acid:alcohol ratio for maximum yield was 1.45 and that the higher the butyric acid concentration the higher the reaction rate. However, as previously described by Grosso et al. [288], elevated concentrations of butyric acid led to enzyme deactivation.

Butyl acetate is another flavour ester with resembling organoleptic properties to pineapple flavour whose production with ROL was reported by Ben Salah et al. [289]. The synthesis of this compound was carried out through esterification reaction of butanol and acetic acid with immobilised proROL onto Celite 545-as preliminary results of the reaction with free enzyme showed poor yield and they were clearly exceeded by the immobilised biocatalyst. According to the authors, solvent-free reaction was chosen as the most suitable strategy because of the easier product purification and lower toxicity and inflammability. In these conditions, a maximum yield of $60 \%$ was obtained and the biocatalyst was stable for three consecutive cycles without a decrease in synthesis activity.

Besides esterification, transesterification reaction catalysed by ROL has also been employed for flavour esters synthesis, for example, Kumari et al. [290] reported isoamyl acetate ester synthesis-pleasant banana flavour-through isoamyl alcohol and vinyl acetate transesterification with immobilised proROL. Furthermore, as stated by these authors, the inhibitory effect of the acid [291] was avoided through the use of transesterification reaction with vinyl acetate ester instead of esterification reaction with the corresponding acid. Under optimal conditions, a conversion of $95 \%$ in $8 \mathrm{~h}$ of reaction was obtained including a great operational stability, after three reaction cycles no activity loss was detected. Garlapati et al. [292] described the use of covalently immobilised proROL onto activated silica to produce through transesterification reactions methyl butyrate and octyl acetate, flavour esters with pineapple and orange odours respectively. As a result of an optimisation process, authors reached high reaction yields in solvent-free system, $70.42 \%$ in $14 \mathrm{~h}$ and $92.35 \%$ in $12 \mathrm{~h}$ for methyl butyrate and octyl acetate respectively. Moreover, in both cases, the biocatalyst was reusable for five times retaining a relative activity of more than $95 \%$. Transesterification reaction was as well employed for citronellol esters synthesis with immobilised proROL into HPMC-PVA polymer (hydroxypropyl methyl cellulose-polyvinyl alcohol) and in supercritical carbon dioxide reaction medium [293]. For the three studied flavour esters (citronellol acetate, citronellol butyrate and citronellol laurate) final yields over $90 \%$ were achieved indicating the suitability of this biocatalysts and the proposed system for these biotransformations.

\subsection{Resolution of Racemic Mixtures}

Enantiomerically pure compounds are very attractive for the preparation of a wide range of products, particularly in food and pharmaceutical industries where the desired organoleptic properties or effects might be only related to one of the isomers. Therefore, racemic resolution processes become relevant and arise the interest in lipases considering the enantioselectivity and specificity of these enzymes [294,295].

Palomo et al. [296] employed proROL to carry out the enzymatic resolution of $(R)$-glycidyl butyrate because of its importance in linezolid synthesis. This product is already sold as a treatment for multidrug resistant Gram-positive infections. According to these authors, they followed the 'conformational engineering' strategy, that is, different techniques for proROL immobilisation were employed. This way, the enzyme structure would have different rigidity or the microenvironment surrounding the enzyme would alter the exact shape of the open form of the lipase influencing its 
catalytic performance. Amongst the three different biocatalysts formed, the best enantiomeric excess (ee) was obtained with proROL immobilised through adsorption on dextran sulphate-coated sepabeads, $99 \%$ ee with a $55 \%$ conversion.

Benzoin is a relevant $\alpha$-hydroxy ketone that might act as building block in organic synthesis. Songür et al. [297] described its enantioselective production from benzoin acetate through the employment of $R$. oryzae cell homogenates (Figure 6). The objective of using cell homogenates was to combine the enantioselective hydrolysis of proROL with the racemisation process of the racemase of $R$. oryzae in order to increase the ee and conversion values. This way, a final conversion of (S)-benzoin close to the $100 \%$ and $96 \%$ ee was achieved.

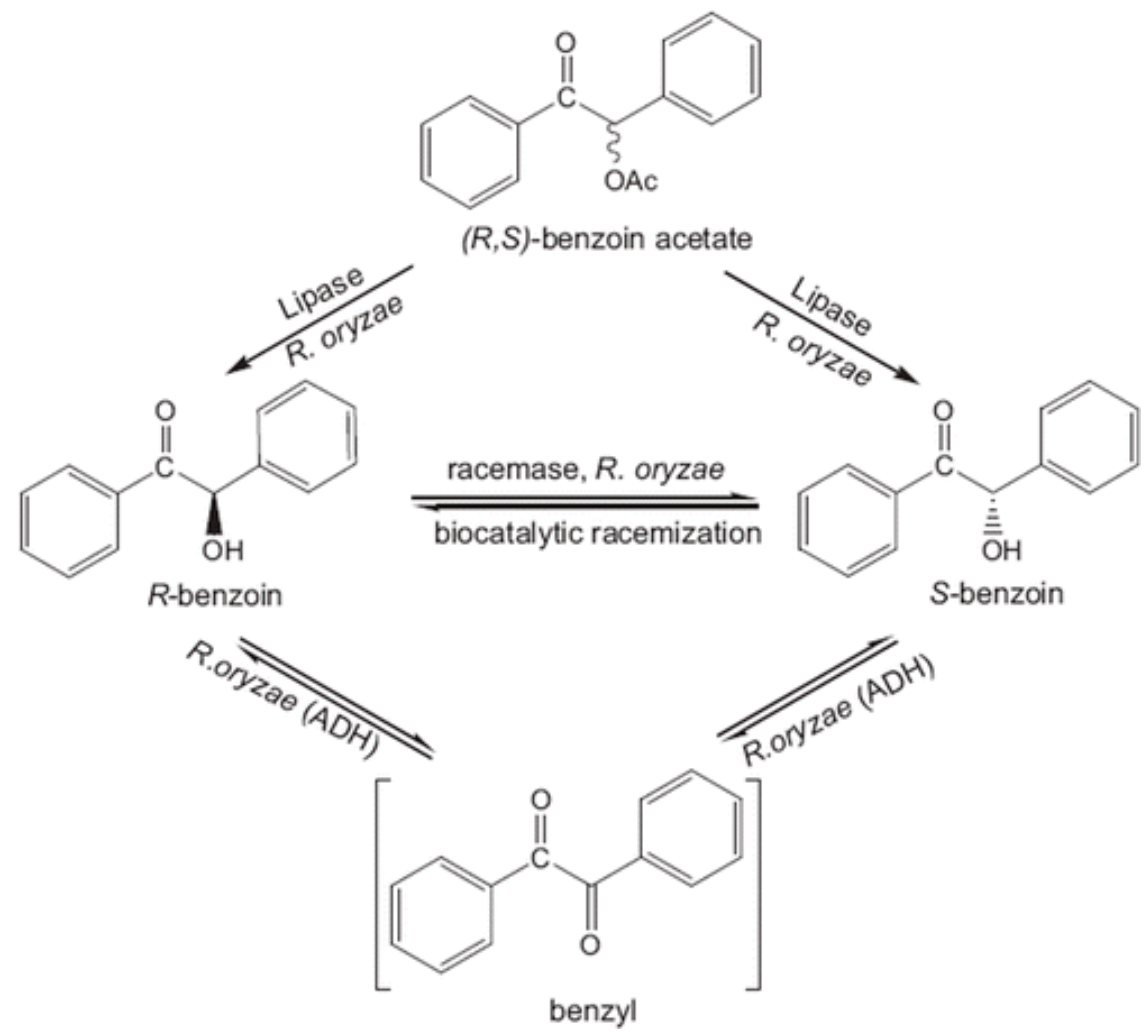

Figure 6. Schematic representation of enantioselective benzoin acetate hydrolysis and deracemisation of benzoin using R. oryzae cells, reproduced with permission from [297]. Copyright 2001, Elsevier.

Covalently immobilised proROL onto Lewatit-aldehyde support has been reported as an adequate biocatalyst for asymmetric hydrolysis of dimethyl 3-phenylglutarate [298]. Under the best conditions, it was possible to obtain the (R)-methyl-3-phenylglutarate with a $92 \%$ ee and an yield in monoester of $97 \%$.

(S)-enantiomer of ibuprofen is 160 more active than its (R)-enantiomer, which can even cause side effects in the gastrointestinal tract. Therefore, obtaining the adequate enantiomer becomes crucial in this case. Yousefi et al. [299] reported the use of immobilised proROL onto octadecyl sepharose to carry out the enantioselective resolution of racemic ibuprofens esters (Figure 7).

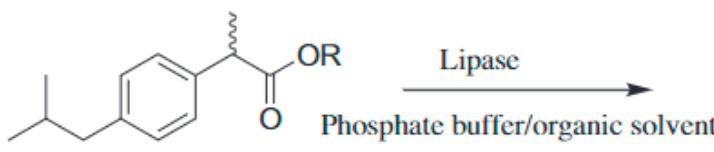

racemic ibuprofen esters<smiles>CC(C)Cc1ccc(C(C)C(=O)O)cc1</smiles>

(S)-ibuprofen<smiles>[R]OC(=O)[C@H](C)c1ccc(CC(C)C)cc1</smiles>

(R)-ibuprofen ester

Figure 7. Lipase-catalysed enantioselective hydrolysis of racemic ibuprofen esters [299]. 
The racemic resolution of $(R, S)-1$-phenylethanol to produce (S)-1-phenylethanol, a chiral building block, was carried out with proROL-displaying yeast whole cell biocatalyst, that is, a $S$. cerevisiae strain genetically modified to display proROL on the cell surface. After $36 \mathrm{~h}$ of reaction, significant results were obtained, $97.3 \%$ yield and $93.3 \%$ ee [300]. The same biocatalyst was employed to catalyse the optical resolution of the pharmaceutical precursor (R,S)-1-benzyloxy-3-chloro-2-propyl monosuccinate. In this case, the operational stability of the biocatalysts was assessed and it was stable after at least eight reaction cycles [301].

Author Contributions: Draft preparation, J.L.-F., F.V.; writing—review and editing, J.L.-F., M.D.B., F.V.; supervision, M.D.B., F.V. All authors have read and agreed to the published version of the manuscript.

Funding: This work was funded by the Project PID2019-104666GB-100 of the Spanish Ministry of Science and Innovation.

Acknowledgments: Josu Lopez-Fernandez acknowledges the award of a scholarship from the Basque Government for the training of pre-doctoral researchers (PRE_2017_1_0110).

Conflicts of Interest: The authors declare no conflict of interest.

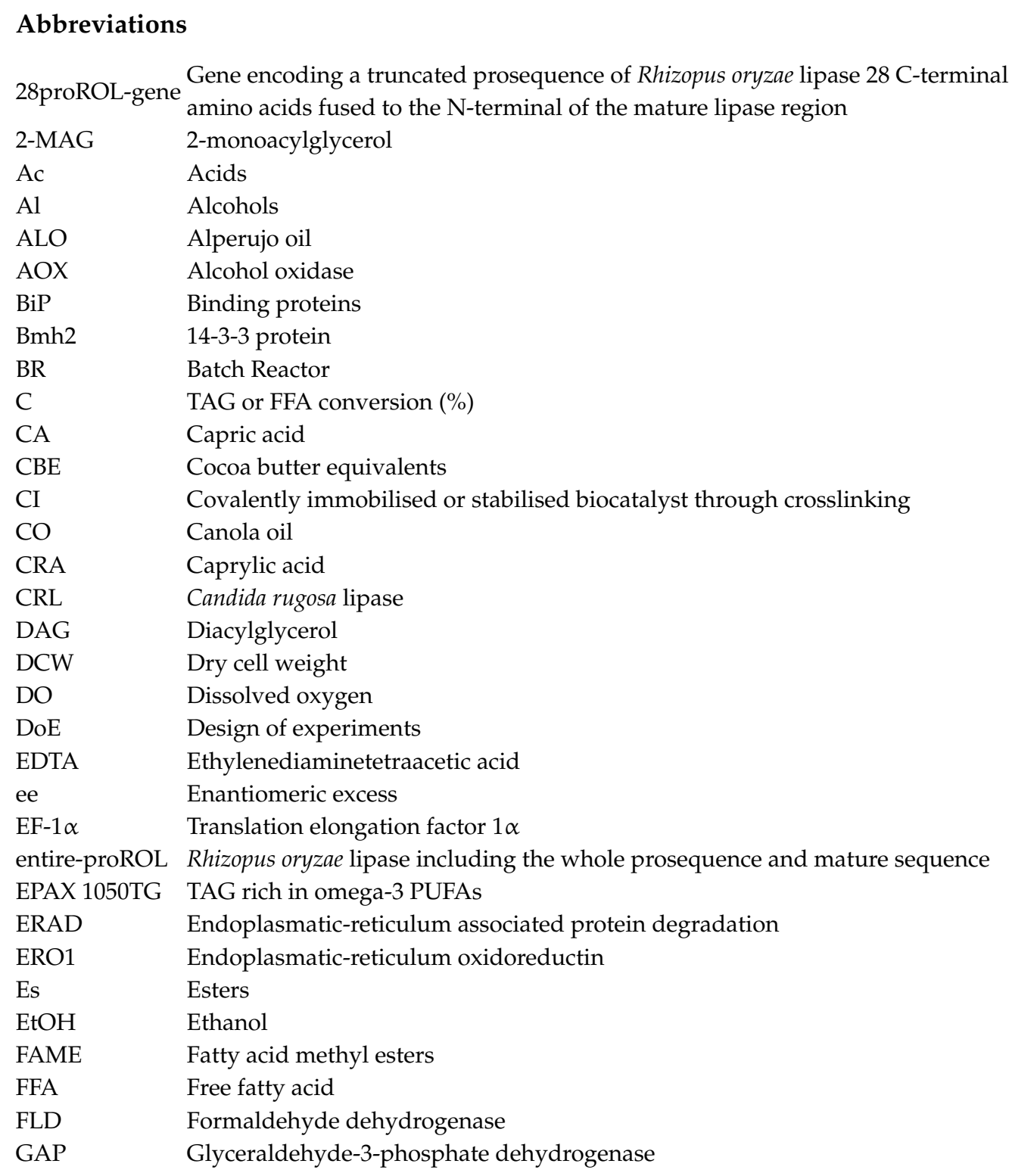




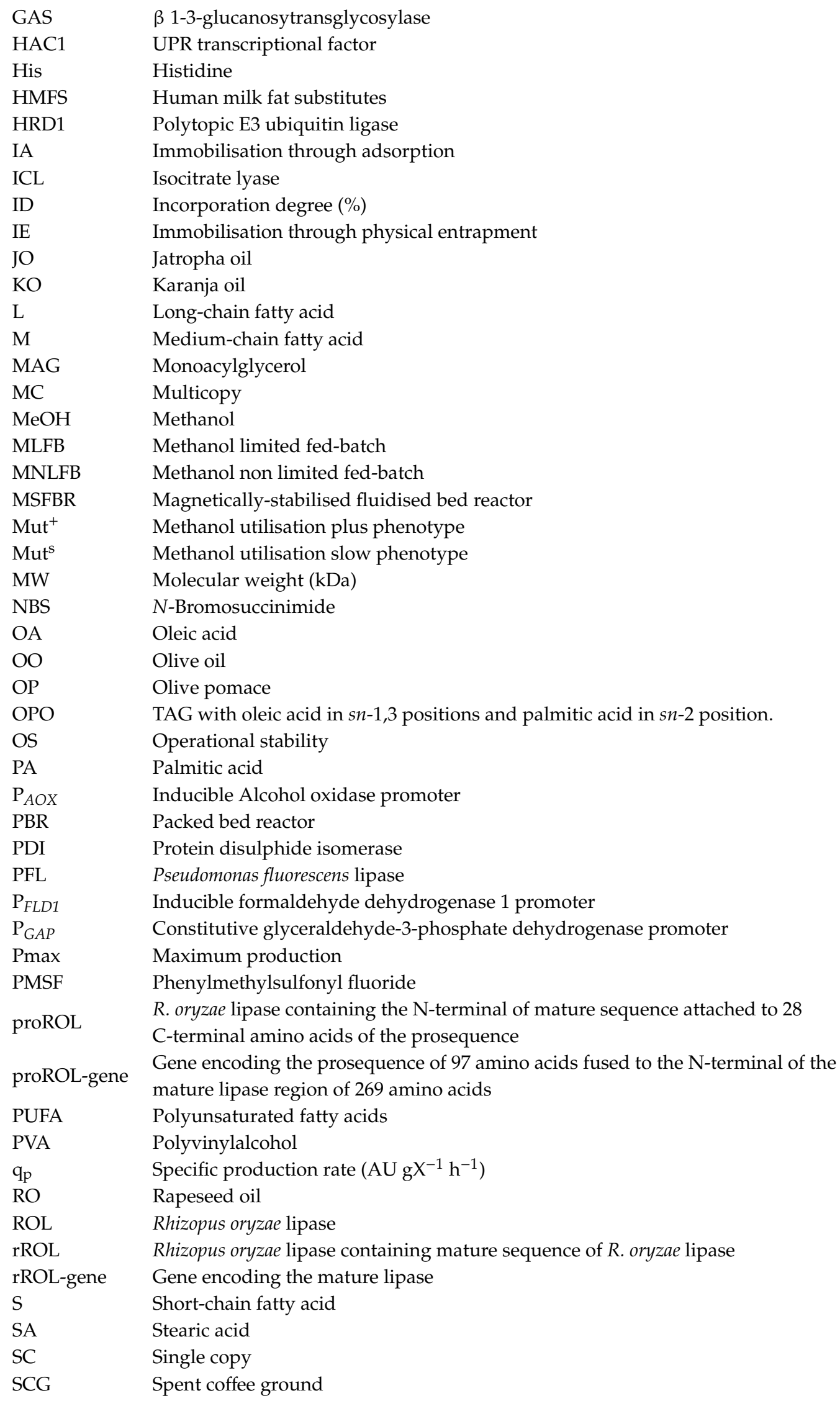




$\begin{array}{ll}\text { SGLB } & \text { Solid gas liquid bioreactor } \\ \text { SL } & \text { structured lipid } \\ \text { SLLB } & \text { Solid liquid liquid bioreactor } \\ \text { SNLFB } & \text { Sorbitol non limited fed-batch } \\ \text { SO } & \text { Sunflower oil } \\ \text { Ssa4 } & \text { Cytosolic chaperone } \\ \text { Sso2 } & \text { Secretion helper factor } \\ \text { STR } & \text { Stirred tank reactor } \\ \text { SYO } & \text { Soybean oil } \\ \text { TAGs } & \text { Triacylglycerols } \\ \text { TGA40 } & \text { commercial oil } \\ \text { TGA55E } & \text { Hydrolysed TGA40 oil } \\ \text { TGA58F } & \text { Mortierella alpina single-cell oil } \\ \text { TPB } & \text { Three phase bioreactor } \\ \text { UBC1 } & \text { Ubiquitin-conjugating enzyme } \\ \text { UPR } & \text { Unfolding protein response } \\ \text { Vhb } & \text { Vitreoscilla haemoglobin } \\ \text { WCB } & \text { Whole cells biocatalyst } \\ \text { WCO } & \text { Waste cooking oil } \\ \text { Y } & \text { Yield (\%) } \\ \text { Y } / X & \text { Product-biomass yield (AU gX }{ }^{-1} \text { ) } \\ \mu & \text { Specific growth rate (h-1) }\end{array}$

\section{References}

1. Chapman, J.; Ismail, A.E.; Dinu, C.Z. Industrial applications of enzymes: Recent advances, techniques, and outlooks. Catalysts 2018, 8, 238. [CrossRef]

2. Singh, R.; Kumar, M.; Mittal, A.; Mehta, P.K. Microbial enzymes: Industrial progress in 21st century. 3 Biotech 2016, 6, 174-189. [CrossRef]

3. Bilal, M.; Cui, J.; Iqbal, H.M.N. Tailoring enzyme microenvironment: State-of-the-art strategy to fulfill the quest for efficient bio-catalysis. Int. J. Biol. Macromol. 2019, 130, 186-196. [CrossRef]

4. Girelli, A.M.; Astolfi, M.L.; Scuto, F.R. Agro-industrial wastes as potential carriers for enzyme immobilization: A review. Chemosphere 2020, 244, 1-12. [CrossRef]

5. Raveendran, S.; Parameswaran, B.; Ummalyma, S.B.; Abraham, A.; Mathew, A.K.; Madhavan, A.; Rebello, S.; Pandey, A. Applications of microbial enzymes in food industry. Food Technol. Biotechnol. 2018, 56, 16-30. [CrossRef] [PubMed]

6. Basso, A.; Serban, S. Industrial applications of immobilized enzymes-A review. Mol. Catal. 2019, 479, 1-20. [CrossRef]

7. Ravindran, R.; Hassan, S.S.; Williams, G.A.; Jaiswal, A.K. A review on bioconversion of agro-industrial wastes to industrially important enzymes. Bioengineering 2018, 5, 93. [CrossRef] [PubMed]

8. Woodley, J.M. Accelerating the implementation of biocatalysis in industry. Appl. Microbiol. Biotechnol. 2019, 103, 4733-4739. [CrossRef]

9. Singh, G.; Arya, S.K. Utility of laccase in pulp and paper industry: A progressive step towards the green technology. Int. J. Biol. Macromol. 2019, 134, 1071-1084. [CrossRef]

10. Publishing, B. Global Markets for Enzymes in Industrial Applications; BCC Publishing: Wellesley, MA, USA, 2018.

11. Li, S.; Yang, X.; Yang, S.; Zhu, M.; Wang, X. Technology prospecting on enzymes: Application, marketing and engineering. Comput. Struct. Biotechnol. J. 2012, 2, 1-11. [CrossRef]

12. Haki, G.D.; Rakshit, S.K. Developments in industrially important thermostable enzymes: A review. Bioresour. Technol. 2003, 89, 17-34. [CrossRef]

13. Dalla-Vecchia, R.; Sebrão, D.; Nascimento, M.D.G.; Soldi, V. Carboxymethylcellulose and poly(vinyl alcohol) used as a film support for lipases immobilization. Process Biochem. 2005, 40, 2677-2682. [CrossRef]

14. Hasan, F.; Shah, A.A.; Hameed, A. Industrial applications of microbial lipases. Enzyme Microb. Technol. 2006, 39, 235-251. [CrossRef] 
15. Sarmah, N.; Revathi, D.; Sheelu, G.; Yamuna Rani, K.; Sridhar, S.; Mehtab, V.; Sumana, C. Recent advances on sources and industrial applications of lipases. Biotechnol. Prog. 2018, 34, 5-28. [CrossRef]

16. Yu, X.W.; Xu, Y.; Xiao, R. Lipases from the genus Rhizopus: Characteristics, expression, protein engineering and application. Prog. Lipid Res. 2016, 64, 57-68. [CrossRef] [PubMed]

17. Melani, N.B.; Tambourgi, E.B.; Silveira, E. Lipases: From Production to Applications. Sep. Purif. Rev. 2020, 49, 143-158. [CrossRef]

18. Lima, R.N.; Porto, A.L.M. Biocatalytic aminolysis of ethyl (S)-mandelate by lipase from Candida antarctica. Catal. Commun. 2017, 100, 157-163. [CrossRef]

19. Paiva, A.L.; Balcão, V.M.; Malcata, F.X. Kinetics and mechanisms of reactions catalyzed by immobilized lipases. Enzyme Microb. Technol. 2000, 27, 187-204. [CrossRef]

20. Zeng, S.; Liu, J.; Anankanbil, S.; Chen, M.; Guo, Z.; Adams, J.P.; Snajdrova, R.; Li, Z. Amide Synthesis via Aminolysis of Ester or Acid with an Intracellular Lipase. ACS Catal. 2018, 8, 8856-8865. [CrossRef]

21. Ken Ugo, A.; Vivian Amara, A.; CN, I.; Kenechuwku, U. Microbial lipases: A prospect for biotechnological industrial catalysis for green products: A review. Ferment Technol. 2017, 6, 144-156. [CrossRef]

22. Bharathi, D.; Rajalakshmi, G. Microbial lipases: An overview of screening, production and purification. Biocatal. Agric. Biotechnol. 2019, 22, 101368-101375. [CrossRef]

23. Borza, P.; Peter, F.; Paul, C. Improved enantioselectivity of Candida antarctica A lipase through sol-gel entrapment. Chem. Bull. Politehnica Univ. 2015, 60, 49-54.

24. Fernandez-Lafuente, R. Lipase from Thermomyces lanuginosus: Uses and prospects as an industrial biocatalyst. J. Mol. Catal. B Enzym. 2010, 62, 197-212. [CrossRef]

25. Guncheva, M.; Zhiryakova, D. Catalytic properties and potential applications of Bacillus lipases. J. Mol. Catal. B Enzym. 2011, 68, 1-21. [CrossRef]

26. Jachmanián, I.; Schulte, E.; Mukherjee, K.D. Substrate selectivity in esterification of less common fatty acids catalysed by lipases from different sources. Appl. Microbiol. Biotechnol. 1996, 44, 563-567. [CrossRef]

27. Barros, M.; Fleuri, L.F.; MacEdo, G.A. Seed lipases: Sources, applications and properties-A review. Brazilian J. Chem. Eng. 2010, 27, 15-29. [CrossRef]

28. Dhake, K.P.; Thakare, D.D.; Bhanage, B.M. Lipase: A potential biocatalyst for the synthesis of valuable flavour and fragrance ester compounds. Flavour Fragr. J. 2013, 28, 71-83. [CrossRef]

29. Su, E.; Xu, J.; You, P. Functional expression of Serratia marcescens H30 lipase in Escherichia coli for efficient kinetic resolution of racemic alcohols in organic solvents. J. Mol. Catal. B Enzym. 2014, 106, 11-16. [CrossRef]

30. Pomeisl, K.; Lamatová, N.; Šolínová, V.; Pohl, R.; Brabcová, J.; Kašička, V.; Krečmerová, M. Enantioselective resolution of side-chain modified gem-difluorinated alcohols catalysed by Candida antarctica lipase B and monitored by capillary electrophoresis. Bioorg. Med. Chem. 2019, 27, 1246-1253. [CrossRef]

31. Javed,S.; Azeem, F.; Hussain, S.; Rasul, I.; Siddique, M.H.; Riaz, M.; Afzal, M.; Kouser, A.; Nadeem, H. Bacterial lipases: A review on purification and characterization. Prog. Biophys. Mol. Biol. 2018, 132, 23-34. [CrossRef]

32. Kapoor, M.; Gupta, M.N. Lipase promiscuity and its biochemical applications. Process. Biochem. 2012, 57, 555-569. [CrossRef]

33. Ribeiro, B.D.; De Castro, A.M.; Coelho, M.A.Z.; Freire, D.M.G. Production and use of lipases in bioenergy: A review from the feedstocks to biodiesel production. Enzyme Res. 2011, 1-16. [CrossRef] [PubMed]

34. Savaghebi, D.; Safari, M.; Rezaei, K.; Ashtari, P.; Farmani, J. Structured lipids produced through lipase-catalyzed acidolysis of canola oil. J. Agric. Sci. Technol. 2012, 14, 1297-1310.

35. Functional Foods from Soybean Oil Deodorizer Distillate using Candida rugosa and Candida Antarctica lipases. Chem. Sci. Trans. 2019, 8, 268-272.

36. Jensen, R.G. Characteristics of the lipase from the mold, Geotrichum candidum: A review. Lipids 1974, 9, 149-157. [CrossRef]

37. Miettinen, H.; Nyyssölä, A.; Rokka, S.; Kontkanen, H.; Kruus, K. Screening of microbes for lipases specific for saturated medium and long-chain fatty acids of milk fat. Int. Dairy J. 2013, 32, 61-67. [CrossRef]

38. Zhao, J.-f.; Lin, J.-p.; Yang, L.-r.; Wu, M.-b. Enhanced performance of Rhizopus oryzae lipase by reasonable immobilization on magnetic nanoparticles and its application in synthesis 1,3-diacyglycerol. Appl. Biochem. Biotechnol. 2019, 188, 677-689. [CrossRef]

39. López-Fernández, J.; Barrero, J.J.; Benaiges, M.D.; Valero, F. Truncated prosequence of Rhizopus oryzae lipase: Key factor for production improvement and biocatalyst stability. Catalysts 2019, 9, 961. [CrossRef] 
40. da S. Pereira, A.; Fontes-Sant'Ana, G.C.; Amaral, P.F.F. Mango agro-industrial wastes for lipase production from Yarrowia lipolytica and the potential of the fermented solid as a biocatalyst. Food Bioprod. Process. 2019, 115, 68-77.

41. Filho, D.G.; Silva, A.G.; Guidini, C.Z. Lipases: Sources, immobilization methods, and industrial applications. Appl. Microbiol. Biotechnol. 2019, 103, 7399-7423. [CrossRef]

42. Thapa, S.; Li, H.; OHair, J.; Bhatti, S.; Chen, F.C.; Nasr, K.A.; Johnson, T.; Zhou, S. Biochemical characteristics of microbial enzymes and their significance from industrial perspectives. Mol. Biotechnol. 2019, 61, 579-601. [CrossRef] [PubMed]

43. Kumar, A.; Dhar, K.; Kanwar, S.S.; Arora, P.K. Lipase catalysis in organic solvents: Advantages and applications. Biol. Proced. Online 2016, 18, 1-11. [CrossRef]

44. Pandey, N.; Dhakar, K.; Jain, R.; Pandey, A. Temperature dependent lipase production from cold and $\mathrm{pH}$ tolerant species of Penicillium. Mycosphere 2016, 7, 1533-1545. [CrossRef]

45. Mehta, A.; Bodh, U.; Gupta, R. Fungal lipases: A review. J. Biotech. Res. 2017, 8, 58-77.

46. Gryganskyi, A.P.; Golan, J.; Dolatabadi, S.; Mondo, S.; Robb, S.; Idnurm, A.; Muszewska, A.; Steczkiewicz, K.; Masonjones, S.; Liao, H.L.; et al. Phylogenetic and phylogenomic definition of Rhizopus species. G3 Genes Genomes Genet. 2018, 8, 2007-2018. [CrossRef] [PubMed]

47. MAA Schipper A revision of the genus Rhizopus. I. The Rhizopus stolonifer-group and Rhizopus oryzae. Stud. Mycol. 1984, 25, 1-19.

48. Abe, A.; Oda, Y.; Asano, K.; Sone, T. The molecular phylogeny of the genus Rhizopus based on rDNA sequences. Biosci. Biotechnol. Biochem. 2006, 70, 2387-2393. [CrossRef] [PubMed]

49. Liu, X.-Y.; Huang, H.; Zheng, R.-Y. Molecular phylogenetic relationships within Rhizopus based on combined analyses of ITS rDNA and pyrG gene sequences. Sydowia 2007, 59, 235-253.

50. Zheng, R.Y.; Chen, G.Q.; Huang, H.; Liu, X.Y. A monograph of Rhizopus. Sydowia 2007, 59, $273-372$.

51. Abe, A.; Asano, K.; Sone, T. A molecular phylogeny-based taxonomy of the genus Rhizopus. Biosci. Biotechnol. Biochem. 2010, 74, 1325-1331. [CrossRef]

52. Londoño-Hernández, L.; Ramírez-Toro, C.; Ruiz, H.A.; Ascacio-Valdés, J.A.; Aguilar-Gonzalez, M.A.; Rodríguez-Herrera, R.; Aguilar, C.N. Rhizopus oryzae-Ancient microbial resource with importance in modern food industry. Int. J. Food Microbiol. 2017, 257, 110-127. [CrossRef]

53. Sebastian, J.; Hegde, K.; Kumar, P.; Rouissi, T.; Brar, S.K. Bioproduction of fumaric acid: An insight into microbial strain improvement strategies. Crit. Rev. Biotechnol. 2019, 39, 817-834. [CrossRef]

54. Benabda, O.; M’Hir, S.; Kasmi, M.; Mnif, W.; Hamdi, M. Optimization of protease and amylase production by Rhizopus oryzae cultivated on bread waste using solid-state fermentation. J. Chem. 2019, 2019, 1-9. [CrossRef]

55. Ghosh, B.; Ray, R.R. Current commercial perspective of Rhizopus oryzae: A review. J. Appl. Sci. 2011, 11, 2470-2486. [CrossRef]

56. Beer, H.D.; McCarthy, J.E.G.; Bornscheuer, U.T.; Schmid, R.D. Cloning, expression, characterization and role of the leader sequence of a lipase from Rhizopus oryzae. Biochim. Biophys. Acta Gene Struct. Expr. 1998, 1399, 173-180. [CrossRef]

57. Salah, R.B.; Mosbah, H.; Fendri, A.; Gargouri, A.; Gargouri, Y.; Mejdoub, H. Biochemical and molecular characterization of a lipase produced by Rhizopus oryzae. FEMS Microbiol. Lett. 2006, 260, 241-248. [CrossRef]

58. Sayari, A.; Frikha, F.; Miled, N.; Mtibaa, H.; Ali, Y.B.; Verger, R.; Gargouri, Y. N-terminal peptide of Rhizopus oryzae lipase is important for its catalytic properties. FEBS Lett. 2005, 579, 976-982. [CrossRef]

59. Derewenda, U.; Swenson, L.; Wei, Y.; Green, R.; Kobos, P.M.; Joerger, R.; Haas, M.J.; Derewenda, Z.S. Conformational lability of lipases observed in the absence of an oil- water interface: Crystallographic studies of enzymes from the fungi Humicola lanuginosa and Rhizopus delemar. J. Lipid Res. 1994, 35, 524-534.

60. Kohno, M.; Kugimiya, W.; Hashimoto, Y.; Morita, Y. Purification, characterization, and crystallization of two types of lipase from Rhizopus niveus. Biosci. Biotechnol. Biochem. 1994, 58, 1007-1012. [CrossRef]

61. Yang, M.; Yu, X.W.; Zheng, H.; Sha, C.; Zhao, C.; Qian, M.; Xu, Y. Role of N-linked glycosylation in the secretion and enzymatic properties of Rhizopus chinensis lipase expressed in Pichia pastoris. Microb. Cell Fact. 2015, 14, 40-54. [CrossRef]

62. Yu, X.W.; Yang, M.; Jiang, C.; Zhang, X.; Xu, Y. N-Glycosylation engineering to improve the constitutive expression of Rhizopus oryzae lipase in Komagataella phaffii. J. Agric. Food Chem. 2017, 65, 6009-6015. [CrossRef]

63. Beer, H.D.; Wohlfahrt, G.; Schmid, R.D.; Mccarthy, J.E.G. The folding and activity of the extracellular lipase of Rhizopus oryzae are modulated by a prosequence. Biochem. J. 1996, 319, 351-359. [CrossRef] 
64. Chen, Y.J.; Inouye, M. The intramolecular chaperone-mediated protein folding. Curr. Opin. Struct. Biol. 2008, 18, 765-770. [CrossRef] [PubMed]

65. Takahashi, S.; Ueda, M.; Atomi, H.; Beer, H.D.; Bornscheuer, U.T.; Schmid, R.D.; Tanaka, A. Extracellular production of active Rhizopus oryzae lipase by Saccharomyces cerevisiae. J. Ferment. Bioeng. 1998, 86, 164-168. [CrossRef]

66. Ueda, M.; Takahashi, S.; Washida, M.; Shiraga, S.; Tanaka, A. Expression of Rhizopus oryzae lipase gene in Saccharomyces cerevisiae. J. Mol. Catal. B Enzym. 2002, 17, 113-124. [CrossRef]

67. Niu, W.; Li, Z.; Tan, T. Secretion of pro- and mature Rhizopus arrhizus lipases by Pichia pastoris and properties of the proteins. Mol. Biotechnol. 2006, 32, 73-81. [CrossRef]

68. Wang, J.R.; Li, Y.Y.; De Xu, S.; Li, P.; Liu, J.S.; Liu, D.N. High-level expression of pro-form lipase from Rhizopus oryzae in Pichia pastoris and its purification and characterization. Int. J. Mol. Sci. 2014, 15, $203-217$. [CrossRef] [PubMed]

69. Takahashi, S.; Ueda, M.; Tanaka, A. Function of the prosequence for in vivo folding and secretion of active Rhizopus oryzae lipase in Saccharomyces cerevisiae. Appl. Microbiol. Biotechnol. 2001, 55, 454-462. [CrossRef]

70. Ben Salah, A.; Sayari, A.; Verger, R.; Gargouri, Y. Kinetic studies of Rhizopus oryzae lipase using monomolecular film technique. Biochimie 2001, 83, 463-469. [CrossRef]

71. Takahashi, S.; Ueda, M.; Tanaka, A. Independent production of two molecular forms of a recombinant Rhizopus oryzae lipase by KEX2-engineered strains of Saccharomyces cerevisiae. Appl. Microbiol. Biotechnol. 1999, 52, 534-540. [CrossRef]

72. Hama, S.; Tamalampudi, S.; Shindo, N.; Numata, T.; Yamaji, H.; Fukuda, H.; Kondo, A. Role of N-terminal 28-amino-acid region of Rhizopus oryzae lipase in directing proteins to secretory pathway of Aspergillus oryzae. Appl. Microbiol. Biotechnol. 2008, 79, 1009-1018. [CrossRef]

73. Minning, S.; Schmidt-Dannert, C.; Schmid, R.D. Functional expression of Rhizopus oryzae lipase in Pichia pastoris: High-level production and some properties. J. Biotechnol. 1998, 66, 147-156. [CrossRef]

74. Takó, M.; Kotogán, A.; Papp, T.; Kadaikunnan, S.; Alharbi, N.S.; Vágvölgyi, C. Purification and properties of extracellular lipases with transesterification activity and 1,3-regioselectivity from Rhizomucor miehei and Rhizopus oryzae. J. Microbiol. Biotechnol. 2017, 27, 277-288. [CrossRef]

75. Hiol, A.; Jonzo, M.D.; Rugani, N.; Druet, D.; Sarda, L.; Comeau, L.C. Purification and characterization of an extracellular lipase from a thermophilic Rhizopus oryzae strain isolated from palm fruit. Enzyme Microb. Technol. 2000, 26, 421-430. [CrossRef]

76. Shimada, Y.; Iwai, M.; Tsujisaka, Y. Reversibility of the modification of Rhizopus delemar lipase by phosphatidylcholine. J. Biochem. 1981, 89, 937-942. [CrossRef]

77. Schrag, J.D.; Cygler, M. 1.8 A refined structure of the lipase from Geotrichum candidum. J. Mol. Biol. 1993, 230, 575-591. [CrossRef]

78. Grochulski, P.; Li, Y.; Schrag, J.D.; Bouthillier, F.; Smith, P.; Harrison, D.; Rubin, B.; Cygler, M. Insights into interfacial activation from an open structure of Candida rugosa lipase. J. Biol. Chem. 1993, 268, 12843-12847.

79. Noble, M.E.M.; Cleasby, A.; Johnson, L.N.; Egmond, M.R.; Frenken, L.G.J. The crystal structure of triacylglycerol lipase from Pseudomonas glumae reveals a partially redundant catalytic aspartate. FEBS Lett. 1993, 331, 123-128. [CrossRef]

80. Derewenda, U.; Swenson, L.; Green, R.; Wei, Y.; Dodson, G.G.; Yamaguchi, S.; Haas, M.J.; Derewenda, Z.S. An unusual buried polar cluster in a family of fungal lipases. Nat. Struct. Biol. 1994, 1, 36-47. [CrossRef]

81. Khan, F.I.; Lan, D.; Durrani, R.; Huan, W.; Zhao, Z.; Wang, Y. The lid domain in lipases: Structural and functional determinant of enzymatic properties. Front. Bioeng. Biotechnol. 2017, 5, 1-13. [CrossRef]

82. Satomura, A.; Kuroda, K.; Ueda, M. Generation of a functionally distinct Rhizopus oryzae lipase through protein folding memory. PLoS ONE 2015, 10, 1-13. [CrossRef] [PubMed]

83. Shiraga, S.; Ueda, M.; Takahashi, S.; Tanaka, A. Construction of the combinatorial library of Rhizopus oryzae lipase mutated in the lid domain by displaying on yeast cell surface. J. Mol. Catal. B Enzym. 2002, 17, 167-173. [CrossRef]

84. Adlercreutz, P. Immobilisation and application of lipases in organic media. Chem. Soc. Rev. 2013, 7, 6406-6436. [CrossRef]

85. Verger, R. "Interfacial activation" of lipases: Facts and artifacts. Trends Biotechnol. 1997, 15, 32-38. [CrossRef]

86. Reis, P.; Holmberg, K.; Watzke, H.; Leser, M.E.; Miller, R. Lipases at interfaces: A review. Adv. Colloid Interface Sci. 2009, 147-148, 237-250. [CrossRef] 
87. Kourist, R.; Brundiek, H.; Bornscheuer, U.T. Protein engineering and discovery of Lipases. Eur. J. Lipid Sci. Technol. 2010, 112, 64-74. [CrossRef]

88. Zhang, Y.; Zhao, Y.; Gao, X.; Jiang, W.; Li, Z.; Yao, Q.; Yang, F.; Wang, F.; Liu, J. Kinetic model of the enzymatic Michael addition for synthesis of mitomycin analogs catalyzed by immobilized lipase from T. laibacchii. Mol. Catal. 2019, 466, 146-156. [CrossRef]

89. Shiraga, S.; Ishiguro, M.; Fukami, H.; Nakao, M.; Ueda, M. Creation of Rhizopus oryzae lipase having a unique oxyanion hole by combinatorial mutagenesis in the lid domain. Appl. Microbiol. Biotechnol. 2005, 68, 779-785. [CrossRef]

90. Guillén, M.; Benaiges, M.D.; Valero, F. Comparison of the biochemical properties of a recombinant lipase extract from Rhizopus oryzae expressed in Pichia pastoris with a native extract. Biochem. Eng. J. 2011, 54, 117-123. [CrossRef]

91. Hermanová, S.; Zarevúcká, M.; Bouša, D.; Pumera, M.; Sofer, Z. Graphene oxide immobilized enzymes show high thermal and solvent stability. Nanoscale 2015, 7, 5852-5858. [CrossRef]

92. Pashangeh, K.; Akhond, M.; Karbalaei-Heidari, H.R.; Absalan, G. Biochemical characterization and stability assessment of Rhizopus oryzae lipase covalently immobilized on amino-functionalized magnetic nanoparticles. Int. J. Biol. Macromol. 2017, 105, 300-307. [CrossRef]

93. Haas, M.J.; Cichowicz, D.J.; Bailey, D.G. Purification and characterization of an extracellular lipase from the fungus Rhizopus delemar. Lipids 1992, 27, 571-576. [CrossRef]

94. Essamri, M.; Deyris, V.; Comeau, L. Optimization of lipase production by Rhizopus oryzae and study on the stability of lipase activity in organic solvents. J. Biotechnol. 1998, 60, 97-103. [CrossRef]

95. Yu, X.W.; Sha, C.; Guo, Y.L.; Xiao, R.; Xu, Y. High-level expression and characterization of a chimeric lipase from Rhizopus oryzae for biodiesel production. Biotechnol. Biofuels 2013, 6, 29-41. [CrossRef]

96. Ben Salah, R.; Gargouri, A.; Verger, R.; Gargouri, Y.; Mejdoub, H. Expression in Pichia pastoris X33 of his-tagged lipase from a novel strain of Rhizopus oryzae and its mutant Asn 134 his: Purification and characterization. World J. Microbiol. Biotechnol. 2009, 25, 1375-1384. [CrossRef]

97. Kantak, J.B.; Prabhune, A.A. Characterization of smallest active monomeric lipase from novel Rhizopus strain: Application in transesterification. Appl. Biochem. Biotechnol. 2012, 166, 1769-1780. [CrossRef]

98. Li, C.; Zhang, G.; Liu, N.; Liu, L. Preparation and properties of Rhizopus oryzae lipase immobilized using an adsorption-crosslinking method. Int. J. Food Prop. 2015, 19, 1776-1785. [CrossRef]

99. Razak, C.N.A.; Salleh, A.B.; Musani, R.; Samad, M.Y.; Basri, M. Some characteristics of lipases from thermophilic fungi isolated from palm oil mill effluent. J. Mol. Catal. B Enzym. 1997, 3, 153-159. [CrossRef]

100. Li, Z.; Li, X.; Wang, Y.; Wang, Y.; Wang, F.; Jiang, J. Expression and characterization of recombinant Rhizopus oryzae lipase for enzymatic biodiesel production. Bioresour. Technol. 2011, 10, 9810-9813. [CrossRef]

101. Song, X.; Qi, X.; Hao, B.; Qu, Y. Studies of substrate specificities of lipases from different sources. Eur. J. Lipid Sci. Technol. 2008, 110, 1095-1101. [CrossRef]

102. Pereira, R.M.; Andrade, G.S.S.; De Castro, H.F.; Campos, M.G.N. Performance of chitosan/glycerol phosphate hydrogel as a support for lipase immobilization. Mater. Res. 2017, 20, 190-201. [CrossRef]

103. Yuzbashev, T.V.; Yuzbasheva, E.Y.; Vibornaya, T.V.; Sobolevskaya, T.I.; Laptev, I.A.; Gavrikov, A.V.; Sineoky, S.P. Production of recombinant Rhizopus oryzae lipase by the yeast Yarrowia lipolytica results in increased enzymatic thermostability. Protein Expr. Purif. 2012, 82, 83-89. [CrossRef]

104. Adak, S.; Banerjee, R. Biochemical characterisation of a newly isolated low molecular eeight lipase from Rhizopus oryzae NRRL. Enzym Eng. 2013, 2, 118-125.

105. Karra-Châabouni, M.; Bouaziz, I.; Boufi, S.; Botelho do Rego, A.M.; Gargouri, Y. Physical immobilization of Rhizopus oryzae lipase onto cellulose substrate: Activity and stability studies. Colloids Surfaces B Biointerfaces 2008, 66, 168-177. [CrossRef]

106. Ebrahimpour, A.; Rahman, R.N.Z.R.A.; Basri, M.; Salleh, A.B. High level expression and characterization of a novel thermostable, organic solvent tolerant, 1,3-regioselective lipase from Geobacillus sp. strain ARM. Bioresour. Technol. 2011, 102, 6972-6981. [CrossRef]

107. Lin, S.F. Production and stabilization of a solvent-tolerant alkaline lipase from Pseudomonas pseudoalcaligenes F-111. J. Ferment. Bioeng. 1996, 82, 448-451. [CrossRef]

108. Lesuisse, E.; Schanck, K.; Colson, C. Purification and preliminary characterization of the extracellular lipase of Bacillus subtilis 168, an extremely basic pH-tolerant enzyme. Eur. J. Biochem. 1993, 216, 155-160. [CrossRef] 
109. Bose, A.; Keharia, H. Production, characterization and applications of organic solvent tolerant lipase by Pseudomonas aeruginosa AAU2. Biocatal. Agric. Biotechnol. 2013, 2, 255-266. [CrossRef]

110. Yan, J.; Yang, J.; Xu, L.; Yan, Y. Gene cloning, overexpression and characterization of a novel organic solvent tolerant and thermostable lipase from Galactomyces geotrichum Y05. J. Mol. Catal. B Enzym. 2007, 49, 28-35. [CrossRef]

111. Zhao, H.; Zheng, L.; Wang, X.; Liu, Y.; Xu, L.; Yan, Y. Cloning, expression and characterization of a new lipase from Yarrowia lipolytica. Biotechnol. Lett. 2011, 33, 2445-2452. [CrossRef]

112. Katiyar, M.; Ali, A. Effect of metal ions on the hydrolytic and transesterification activities of Candida rugosa Lipase. J. Oleo Sci. 2013, 62, 912-924. [CrossRef]

113. Ateşlier, Z.B.B.; Metin, K. Production and partial characterization of a novel thermostable esterase from a thermophilic Bacillus sp. Enzyme Microb. Technol. 2006, 38, 628-635. [CrossRef]

114. Li, W.; Li, R.W.; Li, Q.; Du, W.; Liu, D. Acyl migration and kinetics study of 1(3)-positional specific lipase of Rhizopus oryzae-catalyzed methanolysis of triglyceride for biodiesel production. Process. Biochem. 2010, 45, 1888-1893. [CrossRef]

115. Šinkuniene, D.; Adlercreutz, P. Effects of regioselectivity and lipid class specificity of lipases on transesterification, exemplified by biodiesel production. J. Am. Oil Chem. Soc. 2014, 91, 1283-1290. [CrossRef]

116. Okumura, S.; Iwai, M.; Tsujisaka, Y. Positional specificities of four kinds of microbial lipases. Agric. Biol. Chem. 1976, 40, 655-660. [CrossRef]

117. Canet, A.; Benaiges, M.D.; Valero, F.; Adlercreutz, P. Exploring substrate specificities of a recombinant Rhizopus oryzae lipase in biodiesel synthesis. N. Biotechnol. 2017, 39, 59-67. [CrossRef]

118. Cao, X.; Mangas-Sánchez, J.; Feng, F.; Adlercreutz, P. Acyl migration in enzymatic interesterification of triacylglycerols: Effects of lipases from Thermomyces lanuginosus and Rhizopus oryzae, support material, and water activity. Eur. J. Lipid Sci. Technol. 2016, 118, 1579-1587. [CrossRef]

119. Zaks, A.; Klibanov, A.M. Enzymatic catalysis in nonaqueous solvents. J. Biol. Chem. 1988, 263, 3194-3201.

120. Ben Salah, A.; Fendri, K.; Gargoury, Y. The Enzyme of Rhizopus oryzae-Production, Purification and Biochemical Characteristics. Rev. Fr. Des Corps Gras 1994.

121. Di Lorenzo, M.; Hidalgo, A.; Haas, M.; Bornscheuer, U.T. Heterologous production of functional forms of Rhizopus oryzae lipase in Escherichia coli. Appl. Environ. Microbiol. 2005, 71, 8974-8977. [CrossRef]

122. Çelik, E.; Çalik, P. Production of recombinant proteins by yeast cells. Biotechnol. Adv. 2012, 30, 1108-1118. [CrossRef]

123. Juturu, V.; Wu, J.C. Heterologous protein expression in Pichia pastoris: Latest research progress and applications. ChemBioChem 2018, 19, 7-21. [CrossRef] [PubMed]

124. Ahmad, M.; Hirz, M.; Pichler, H.; Schwab, H. Protein expression in Pichia pastoris: Recent achievements and perspectives for heterologous protein production. Appl. Microbiol. Biotechnol. 2014, 98, 5301-5317. [CrossRef]

125. García-Ortega, X.; Cámara, E.; Ferrer, P.; Albiol, J.; Montesinos-Seguí, J.L.; Valero, F. Rational development of bioprocess engineering strategies for recombinant protein production in Pichia pastoris (Komagataella phaffii) using the methanol-free GAP promoter. Where do we stand? N. Biotechnol. 2019, 53, 24-34. [CrossRef]

126. Mattanovich, D.; Graf, A.; Stadlmann, J.; Dragosits, M.; Redl, A.; Maurer, M.; Kleinheinz, M.; Sauer, M.; Altmann, F.; Gasser, B. Genome, secretome and glucose transport highlight unique features of the protein production host Pichia pastoris. Microb. Cell Fact. 2009, 8. [CrossRef] [PubMed]

127. Hemmerich, J.; Adelantado, N.; Barrigón, J.M.; Ponte, X.; Hörmann, A.; Ferrer, P.; Kensy, F.; Valero, F. Comprehensive clone screening and evaluation of fed-batch strategies in a microbioreactor and lab scale stirred tank bioreactor system: Application on Pichia pastoris producing Rhizopus oryzae lipase. Microb. Cell Fact. 2014, 13, 36-52. [CrossRef]

128. Minning, S.; Serrano, A.; Ferrer, P.; Solá, C.; Schmid, R.D.; Valero, F. Optimization of the high-level production of Rhizopus oryzae lipase in Pichia pastoris. J. Biotechnol. 2001, 86, 59-70. [CrossRef]

129. Cos, O.; Serrano, A.; Montesinos, J.L.; Ferrer, P.; Cregg, J.M.; Valero, F. Combined effect of the methanol utilization (Mut) phenotype and gene dosage on recombinant protein production in Pichia pastoris fed-batch cultures. J. Biotechnol. 2005, 116, 321-335. [CrossRef]

130. Surribas, A.; Stahn, R.; Montesinos, J.L.; Enfors, S.O.; Valero, F.; Jahic, M. Production of a Rhizopus oryzae lipase from Pichia pastoris using alternative operational strategies. J. Biotechnol. 2007, 130, 291-299. [CrossRef] [PubMed] 
131. Barrigón, J.M.; Montesinos, J.L.; Valero, F. Searching the best operational strategies for Rhizopus oryzae lipase production in Pichia pastoris Mut+phenotype: Methanol limited or methanol non-limited fed-batch cultures? Biochem. Eng. J. 2013, 75, 47-54. [CrossRef]

132. Ponte, X.; Montesinos-Seguí, J.L.; Valero, F. Bioprocess efficiency in Rhizopus oryzae lipase production by Pichia pastoris under the control of $P_{A O X 1}$ is oxygen tension dependent. Process. Biochem. 2016, 51, 1954-1963. [CrossRef]

133. Canales, C.; Altamirano, C.; Berrios, J. Effect of dilution rate and methanol-glycerol mixed feeding on heterologous Rhizopus oryzae lipase production with Pichia pastoris Mut+ phenotype in continuous culture. Biotechnol. Prog. 2015, 31, 707-714. [CrossRef]

134. Cos, O.; Ramon, R.; Montesinos, J.L.; Valero, F. A simple model-based control for Pichia pastoris allows a more efficient heterologous protein production bioprocess. Biotechnol. Bioeng. 2006, 95, 145-154. [CrossRef]

135. Arnau, C.; Ramon, R.; Casas, C.; Valero, F. Optimization of the heterologous production of a Rhizopus oryzae lipase in Pichia pastoris system using mixed substrates on controlled fed-batch bioprocess. Enzyme Microb. Technol. 2010, 46, 494-500. [CrossRef]

136. Arnau, C.; Casas, C.; Valero, F. The effect of glycerol mixed substrate on the heterologous production of a Rhizopus oryzae lipase in Pichia pastoris system. Biochem. Eng. J. 2011, 57, 30-37. [CrossRef]

137. Resina, D.; Cos, O.; Ferrer, P.; Valero, F. Developing high cell density fed-batch cultivation strategies for heterologous protein production in Pichia pastoris using the nitrogen source-regulated FLD1 promoter. Biotechnol. Bioeng. 2005, 91, 760-767. [CrossRef]

138. Resina, D.; Maurer, M.; Cos, O.; Arnau, C.; Carnicer, M.; Marx, H.; Gasser, B.; Valero, F.; Mattanovich, D.; Ferrer, P. Engineering of bottlenecks in Rhizopus oryzae lipase production in Pichia pastoris using the nitrogen source-regulated FLD1 promoter. N. Biotechnol. 2009, 25, 396-403. [CrossRef] [PubMed]

139. Yu, X.W.; Lu, X.; Zhao, L.S.; Xu, Y. Impact of NH4 ${ }^{+}$nitrogen source on the production of Rhizopus oryzae lipase in Pichia pastoris. Process. Biochem. 2013, 48, 1462-1468. [CrossRef]

140. Jiao, L.; Zhou, Q.; Su, Z.; Xu, L.; Yan, Y. High-level extracellular production of Rhizopus oryzae lipase in Pichia pastoris via a strategy combining optimization of gene-copy number with co-expression of ERAD-related proteins. Protein Expr. Purif. 2018, 147, 1-12. [CrossRef]

141. Jiao, L.; Zhou, Q.; Su, Z.; Yan, Y. Efficient heterologous production of Rhizopus oryzae lipase via optimization of multiple expression-related helper proteins. Int. J. Mol. Sci. 2018, 19, 3372. [CrossRef]

142. Ponte, X.; Barrigón, J.M.; Maurer, M.; Mattanovich, D.; Valero, F.; Montesinos-Seguí, J.L. Towards optimal substrate feeding for heterologous protein production in Pichia pastoris (Komagataella spp) fed-batch processes under PAOX1 control: A modeling aided approach. J. Chem. Technol. Biotechnol. 2018, 93, 3208-3218. [CrossRef]

143. Li, X.; He, X.; Li, Z.; Wang, F. Combined strategies for improving the production of recombinant Rhizopus oryzae lipase in Pichia pastoris. BioResources 2013, 8, 2867-2880. [CrossRef]

144. Ramón, R.; Ferrer, P.; Valero, F. Sorbitol co-feeding reduces metabolic burden caused by the overexpression of a Rhizopus oryzae lipase in Pichia pastoris. J. Biotechnol. 2007, 130, 39-46. [CrossRef]

145. Resina, D.; Serrano, A.; Valero, F.; Ferrer, P. Expression of a Rhizopus oryzae lipase in Pichia pastoris under control of the nitrogen source-regulated formaldehyde dehydrogenase promoter. J. Biotechnol. 2004, 109, 103-113. [CrossRef]

146. Cos, O.; Resina, D.; Ferrer, P.; Montesinos, J.L.; Valero, F. Heterologous production of Rhizopus oryzae lipase in Pichia pastoris using the alcohol oxidase and formaldehyde dehydrogenase promoters in batch and fed-batch cultures. Biochem. Eng. J. 2005, 26, 86-94. [CrossRef]

147. Alhadeff, E.M.; Salgado, A.M.; Cos, O.; Pereira, N.; Valdman, B.; Valero, F. Enzymatic microreactors for the determination of ethanol by an automatic sequential injection analysis system. Appl. Biochem. Biotechnol. 2007, 137, 17-25.

148. Marx, H.; Sauer, M.; Resina, D.; Vai, M.; Porro, D.; Valero, F.; Ferrer, P.; Mattanovich, D. Cloning, disruption and protein secretory phenotype of the GAS1 homologue of Pichia pastoris. FEMS Microbiol. Lett. 2006, 264, 40-47. [CrossRef] [PubMed]

149. Gasser, B.; Sauer, M.; Maurer, M.; Stadlmayr, G.; Mattanovich, D. Transcriptomics-based identification of novel factors enhancing heterologous protein secretion in yeasts. Appl. Environ. Microbiol. 2007, 73, 6499-6507. [CrossRef] 
150. Sha, C.; Yu, X.W.; Zhang, M.; Xu, Y. Efficient secretion of lipase r27RCL in Pichia pastoris by enhancing the disulfide bond formation pathway in the endoplasmic reticulum. J. Ind. Microbiol. Biotechnol. 2013, 40, 1241-1249. [CrossRef]

151. Li, W.; Du, W.; Liu, D. Rhizopus oryzae IFO 4697 whole cell catalyzed methanolysis of crude and acidified rapeseed oils for biodiesel production in tert-butanol system. Process. Biochem. 2007, 42, 1481-1485. [CrossRef]

152. Li, W.; Du, W.; Liu, D. Optimization of whole cell-catalyzed methanolysis of soybean oil for biodiesel production using response surface methodology. J. Mol. Catal. B Enzym. 2007, 45, 122-127. [CrossRef]

153. Hama, S.; Yamaji, H.; Kaieda, M.; Oda, M.; Kondo, A.; Fukuda, H. Effect of fatty acid membrane composition on whole-cell biocatalysts for biodiesel-fuel production. Biochem. Eng. J. 2004, 21, 155-160. [CrossRef]

154. Matsumoto, T.; Takahashi, S.; Kaieda, M.; Ueda, M.; Tanaka, A.; Fukuda, H.; Kondo, A. Yeast whole-cell biocatalyst constructed by intracellular overproduction of Rhizopus oryzae lipase is applicable to biodiesel fuel production. Appl. Microbiol. Biotechnol. 2001, 57, 515-520.

155. Matsumoto, T.; Takahashi, S.; Ueda, M.; Tanaka, A.; Fukuda, H.; Kondo, A. Preparation of high activity yeast whole cell bioctalysts by optimization of intracellular production of recombinant Rhizopus oryzae lipase. J. Mol. Catal. B Enzym. 2002, 17, 143-149. [CrossRef]

156. Tanino, T.; Fukuda, H.; Kondo, A. Construction of a Pichia pastoris cell-surface display system using Flo1p anchor system. Biotechnol. Prog. 2006, 22, 983-999. [CrossRef]

157. Li, W.; Shi, H.; Ding, H.; Wang, L.; Zhang, Y.; Li, X.; Wang, F. Cell surface display and characterization of Rhizopus oryzae lipase in Pichia pastoris using Sed1p as an anchor protein. Curr. Microbiol. 2015, 71, 150-155. [CrossRef]

158. Thomas, S.M.; DiCosimo, R.; Nagarajan, V. Biocatalysis: Applications and potentials for the chemical industry. Trends Biotechnol. 2002, 20, 238-242. [CrossRef]

159. Tenenbaum, D.J. Food vs. fuel diversion of crops could cause more hunger. Environ. Health Perspect. 2008, 116, A254-A257. [CrossRef]

160. Amin, A. Review of diesel production from renewable resources: Catalysis, process kinetics and technologies. Ain Shams Eng. J. 2019, 201, 112155-112170. [CrossRef]

161. Singh, D.; Sharma, D.; Soni, S.L.; Sharma, S.; Kumar Sharma, P.; Jhalani, A. A review on feedstocks, production processes, and yield for different generations of biodiesel. Fuel 2020, 262, 116553-116568. [CrossRef]

162. Yew, G.Y.; Lee, S.Y.; Show, P.L.; Tao, Y.; Law, C.L.; Nguyen, T.T.C.; Chang, J.S. Recent advances in algae biodiesel production: From upstream cultivation to downstream processing. Bioresour. Technol. Reports 2019, 7. [CrossRef]

163. Sitepu, I.R.; Garay, L.A.; Sestric, R.; Levin, D.; Block, D.E.; German, J.B.; Boundy-Mills, K.L. Oleaginous yeasts for biodiesel: Current and future trends in biology and production. Biotechnol. Adv. 2014, 32, 1336-1360. [CrossRef]

164. Singh, D.; Sharma, D.; Soni, S.L.; Sharma, S.; Kumari, D. Chemical compositions, properties, and standards for different generation biodiesels: A review. Fuel 2019, 253, 60-71. [CrossRef]

165. Ambat, I.; Srivastava, V.; Sillanpää, M. Recent advancement in biodiesel production methodologies using various feedstock: A review. Renew. Sustain. Energy Rev. 2018, 90, 356-369. [CrossRef]

166. Ranganathan, S.V.; Narasimhan, S.L.; Muthukumar, K. An overview of enzymatic production of biodiesel. Bioresour. Technol. 2008, 99, 3975-3981. [CrossRef]

167. Guldhe, A.; Singh, B.; Mutanda, T.; Permaul, K.; Bux, F. Advances in synthesis of biodiesel via enzyme catalysis: Novel and sustainable approaches. Renew. Sustain. Energy Rev. 2015, 41, 1447-1464. [CrossRef]

168. Christopher, L.P.; Kumar, H.; Zambare, V.P. Enzymatic biodiesel: Challenges and opportunities. Appl. Energy 2014, 119, 497-520. [CrossRef]

169. Santos, S.; Puna, J.; Gomes, J. A review on bio-based catalysts (immobilized enzymes) used for biodiesel production. Energies 2020, 13, 3013. [CrossRef]

170. Bonet-Ragel, K.; Canet, A.; Benaiges, M.D.; Valero, F. Synthesis of biodiesel from high FFA alperujo oil catalysed by immobilised lipase. Fuel 2015, 161, 12-17. [CrossRef]

171. Lin, Y.H.; Luo, J.J.; John Hwang, S.C.; Liau, P.R.; Lu, W.J.; Lee, H.T. The influence of free fatty acid intermediate on biodiesel production from soybean oil by whole cell biocatalyst. Biomass Bioenergy 2011, 35, 2217-2223. [CrossRef] 
172. Aghababaie, M.; Beheshti, M.; Razmjou, A.; Bordbar, A.K. Enzymatic biodiesel production from crude Eruca sativa oil using Candida rugosa lipase in a solvent-free system using response surface methodology. Biofuels 2020, 11, 93-99. [CrossRef]

173. Guldhe, A.; Singh, P.; Renuka, N.; Bux, F. Biodiesel synthesis from wastewater grown microalgal feedstock using enzymatic conversion: A greener approach. Fuel 2019, 237, 1112-1118. [CrossRef]

174. Moreira, K.S.; Moura, L.S.; Monteiro, R.R.C.; de Oliveira, A.L.B.; Valle, C.P.; Freire, T.M.; Fechine, P.B.A.; de Souza, M.C.M.; Fernandez-Lorente, G.; Guisan, J.M.; et al. Optimization of the Production of Enzymatic Biodiesel from Residual Babassu Oil (Orbignya sp.) via RSM. Catalysts 2020, 10, 414. [CrossRef]

175. Fedosov, S.N.; Brask, J.; Pedersen, A.K.; Nordblad, M.; Woodley, J.M.; Xu, X. Kinetic model of biodiesel production using immobilized lipase Candida antarctica lipase B. J. Mol. Catal. B Enzym. 2013, 85-86, 156-168. [CrossRef]

176. Liu, L.H.; Shih, Y.H.; Liu, W.L.; Lin, C.H.; Huang, H.Y. Enzyme Immobilized on nanoporous carbon derived from metal-organic framework: A new support for biodiesel synthesis. ChemSusChem 2017, 10, 1364-1369. [CrossRef]

177. Shah, S.; Gupta, M.N. The effect of ultrasonic pre-treatment on the catalytic activity of lipases in aqueous and non-aqueous media. Chem. Cent. J. 2008, 2. [CrossRef] [PubMed]

178. Estevez, R.; Aguado-Deblas, L.; Bautista, F.M.; Luna, D.; Luna, C.; Calero, J.; Posadillo, A.; Romero, A.A. Biodiesel at the crossroads: A critical review. Catalysts 2019, 9, 1033. [CrossRef]

179. Dunn, R.O. Effects of monoacylglycerols on the cold flow properties of biodiesel. J. Am. Oil Chem. Soc. 2012, 89, 1509-1520. [CrossRef]

180. Calero, J.; Verdugo, C.; Luna, D.; Sancho, E.D.; Luna, C.; Posadillo, A.; Bautista, F.M.; Romero, A.A. Selective ethanolysis of sunflower oil with Lipozyme RM IM, an immobilized Rhizomucor miehei lipase, to obtain a biodiesel-like biofuel, which avoids glycerol production through the monoglyceride formation. N. Biotechnol. 2014, 31, 596-601. [CrossRef]

181. Bonet-Ragel, K.; Canet, A.; Benaiges, M.D.; Valero, F. Effect of acyl-acceptor stepwise addition strategy using alperujo oil as a substrate in enzymatic biodiesel synthesis. J. Chem. Technol. Biotechnol. 2018, 93, 541-547. [CrossRef]

182. Fredrick, E.; Moens, K.; Heyman, B.; Fischer, S.; Van der Meeren, P.; Dewettinck, K. Monoacylglycerols in dairy recombined cream: I. The effect on milk fat crystallization. Food Res. Int. 2013, 51, 892-898. [CrossRef]

183. Itabaiana, I.; Gonçalves, K.M.; Cordeiro, Y.M.L.; Zoumpanioti, M.; Leal, I.C.R.; Miranda, L.S.M.; De Souza, R.O.M.A.; Xenakis, A. Kinetics and mechanism of lipase catalyzed monoacylglycerols synthesis. J. Mol. Catal. B Enzym. 2013, 96, 34-39. [CrossRef]

184. Feltes, M.M.C.; de Oliveira, D.; Block, J.M.; Ninow, J.L. The production, benefits, and applications of monoacylglycerols and diacylglycerols of nutritional interest. Food Bioprocess. Technol. 2013, 6, 17-35. [CrossRef]

185. Canet, A.; Bonet-Ragel, K.í.; Benaiges, M.D.; Valero, F. Biodiesel synthesis in a solvent-free system by recombinant Rhizopus oryzae: Comparative study between a stirred tank and a packed-bed batch reactor. Biocatal. Biotransform. 2017, 35, 35-40. [CrossRef]

186. Ciudad, G.; Reyes, I.; Jorquera, M.A.; Azócar, L.; Wick, L.Y.; Navia, R. Novel three-phase bioreactor concept for fatty acid alkyl ester production using R. oryzae as whole cell catalyst. World J. Microbiol. Biotechnol. 2011, 27, 2505-2512. [CrossRef]

187. Jang, M.G.; Kim, D.K.; Park, S.C.; Lee, J.S.; Kim, S.W. Biodiesel production from crude canola oil by two-step enzymatic processes. Renew. Energy 2012, 42, 99-104. [CrossRef]

188. He, Q.; Shi, H.; Gu, H.; Naka, G.; Ding, H.; Li, X.; Zhang, Y.; Hu, B.; Wang, F. Immobilization of Rhizopus oryzae ly6 onto loofah sponge as a whole-cell biocatalyst for biodiesel production. BioResources 2016, 11, 850-860. [CrossRef]

189. Su, F.; Li, G.L.; Fan, Y.L.; Yan, Y.J. Enhancing biodiesel production via a synergic effect between immobilized Rhizopus oryzae lipase and Novozym Fuel Process. Technol. 2015, 137, 298-304.

190. Zhou, G.-x.; Chen, G.-y.; Yan, B.-b. Biodiesel production in a magnetically-stabilized, fluidized bed reactor with an immobilized lipase in magnetic chitosan microspheres. Biotechnol. Lett. 2014, 36, 63-68. [CrossRef]

191. Hama, S.; Yamaji, H.; Fukumizu, T.; Numata, T.; Tamalampudi, S.; Kondo, A.; Noda, H.; Fukuda, H. Biodiesel-fuel production in a packed-bed reactor using lipase-producing Rhizopus oryzae cells immobilized within biomass support particles. Biochem. Eng. J. 2007, 34, 273-278. [CrossRef] 
192. Luna, C.; Verdugo, C.; Sancho, E.D.; Luna, D.; Calero, J.; Posadillo, A.; Bautista, F.M.; Romero, A.A. Biocatalytic behaviour of immobilized Rhizopus oryzae lipase in the 1,3-selective ethanolysis of sunflower oil to obtain a biofuel similar to biodiesel. Molecules 2014, 19, 11419-11439. [CrossRef]

193. Luna, C.; Verdugo, C.; Sancho, E.D.; Luna, D.; Calero, J.; Posadillo, A.; Bautista, F.M.; Romero, A.A. A biofuel similar to biodiesel obtained by using a lipase from Rhizopus oryzae, optimized by response surface methodology. Energies 2014, 7, 3383-3399. [CrossRef]

194. Meher, L.C.; Churamani, C.P.; Ahmed, Z.; Naik, S.N. Jatropha curcas as a renewable source for bio-fuels-A review. Renew. Sustain. Energy Rev. 2013, 26, 397-407. [CrossRef]

195. Rodrigues, J.; Perrier, V.; Lecomte, J.; Dubreucq, E.; Ferreira-Dias, S. Biodiesel production from crude jatropha oil catalyzed by immobilized lipase/acyltransferase from Candida parapsilosis in aqueous medium. Bioresour. Technol. 2016, 218, 1224-1229. [CrossRef]

196. Li, X.; He, X.Y.; Li, Z.L.; Wang, Y.D.; Wang, C.Y.; Shi, H.; Wang, F. Enzymatic production of biodiesel from Pistacia chinensis bge seed oil using immobilized lipase. Fuel 2012, 92, 89-93. [CrossRef]

197. Arumugam, A.; Ponnusami, V. Biodiesel production from Calophyllum inophyllum oil using lipase producing Rhizopus oryzae cells immobilized within reticulated foams. Renew. Energy 2014, 64, 276-282. [CrossRef]

198. Navarro López, E.; Robles Medina, A.; González Moreno, P.A.; Esteban Cerdán, L.; Martín Valverde, L.; Molina Grima, E. Biodiesel production from Nannochloropsis gaditana lipids through transesterification catalyzed by Rhizopus oryzae lipase. Bioresour. Technol. 2016, 203, 233-244. [CrossRef]

199. Navarro López, E.; Robles Medina, A.; González Moreno, P.A.; Esteban Cerdán, L.; Molina Grima, E. Extraction of microalgal lipids and the influence of polar lipids on biodiesel production by lipase-catalyzed transesterification. Bioresour. Technol. 2016, 216, 904-913. [CrossRef]

200. Araya, K.; Ugarte, A.; Azócar, L.; Valerio, O.; Wick, L.Y.; Ciudad, G. Whole cell three phase bioreactors allow for effective production of fatty acid alkyl esters derived from microalgae lipids. Fuel 2015, 144, 25-32. [CrossRef]

201. Nematian, T.; Salehi, Z.; Shakeri, A. Conversion of bio-oil extracted from Chlorella vulgaris micro algae to biodiesel via modified superparamagnetic nano-biocatalyst. Renew. Energy 2020, 146, 1796-1804. [CrossRef]

202. Muanruksa, P.; Kaewkannetra, P. Combination of fatty acids extraction and enzymatic esterification for biodiesel production using sludge palm oil as a low-cost substrate. Renew. Energy 2020, 146, 901-906. [CrossRef]

203. Karmee, S.K.; Swanepoel, W.; Marx, S. Biofuel production from spent coffee grounds via lipase catalysis. Energy Sour. Part A Recovery Util. Environ. Eff. 2018, 40, 294-300. [CrossRef]

204. Bharathiraja, B.; Ranjithkumar, R.; Chakravarthy, M.; Yogendran, D.; Vivek, P.; Yuvaraj, D.; Kumar, R.P.; Palani, S. Kinetic analysis of fatty acid alkyl esters using whole cell biocatalyst and lipase catalyzed transesterification from waste cooking oil. Asian J. Microbiol. Biotechnol. Environ. Sci. 2014, 16, 745-752.

205. Syed, M.B.; Ali, M.Y.; Ishaq, M.; Bakkiyaraj, S.; Devanesan, M.G.; Tangavelu, V. Response surface optimization of biodiesel production using immobilized Rhizopus oryzae cells. Biofuels 2016, 7, 1-8. [CrossRef]

206. Sun, T.; Du, W.; Liu, D. Comparative study on stability of whole cells during biodiesel production in solvent-free system. Process. Biochem. 2011, 46, 661-664. [CrossRef]

207. Ban, K.; Hama, S.; Nishizuka, K.; Kaieda, M.; Matsumoto, T.; Kondo, A.; Noda, H.; Fukuda, H. Repeated use of whole-cell biocatalysts immobilized within biomass support particles for biodiesel fuel production. J. Mol. Catal. B Enzym. 2002, 17, 157-165. [CrossRef]

208. Bonet-Ragel, K.; López-Pou, L.; Tutusaus, G.; Benaiges, M.D.; Valero, F. Rice husk ash as a potential carrier for the immobilization of lipases applied in the enzymatic production of biodiesel. Biocatal. Biotransform. 2018, 36, 151-158. [CrossRef]

209. Duarte, S.H.; del Peso Hernández, G.L.; Canet, A.; Benaiges, M.D.; Maugeri, F.; Valero, F. Enzymatic biodiesel synthesis from yeast oil using immobilized recombinant Rhizopus oryzae lipase. Bioresour. Technol. 2015, 183, 175-180. [CrossRef]

210. Su, F.; Li, G.; Zhang, H.; Yan, Y. Enhanced performance of Rhizopus oryzae lipase immobilized on hydrophobic carriers and its application in biorefinery of rapeseed oil deodorizer distillate. Bioenergy Res. 2014, 7, 935-945. [CrossRef]

211. Bakkiyaraj, S.; Syed, M.B.; Devanesan, M.G.; Thangavelu, V. Production and optimization of biodiesel using mixed immobilized biocatalysts in packed bed reactor. Environ. Sci. Pollut. Res. 2016, 23, 9276-9283. [CrossRef] 
212. Balasubramanian, B.; Ramanujam, P.K.; Ravi Kumar, R.; Muninathan, C.; Dhinakaran, Y. Optimization of biological transesterification of waste cooking oil in different solvents using response surface methodology. Manag. Environ. Qual. An. Int. J. 2016, 27, 537-550. [CrossRef]

213. Nematian, T.; Shakeri, A.; Salehi, Z.; Saboury, A.A. Lipase immobilized on functionalized superparamagnetic few-layer graphene oxide as an efficient nanobiocatalyst for biodiesel production from Chlorella vulgaris bio-oil. Biotechnol. Biofuels 2020, 13. [CrossRef]

214. Athalye, S.; Sharma-Shivappa, R.; Peretti, S.; Kolar, P.; Davis, J.P. Producing biodiesel from cottonseed oil using Rhizopus oryzae ATCC \#34612 whole cell biocatalysts: Culture media and cultivation period optimization. Energy Sustain. Dev. 2013, 17, 331-336.

215. Vipin, V.C.; Sebastian, J.; Muraleedharan, C.; Santhiagu, A. Enzymatic transesterification of rubber seed oil using Rhizopus oryzae Lipase. Procedia Technol. 2016, 25, 1014-1021. [CrossRef]

216. Lee, J.H.; Kim, S.B.; Kang, S.W.; Song, Y.S.; Park, C.; Han, S.O.; Kim, S.W. Biodiesel production by a mixture of Candida rugosa and Rhizopus oryzae lipases using a supercritical carbon dioxide process. Bioresour. Technol. 2011, 102, 2105-2108. [CrossRef]

217. Zeng, L.; He, Y.; Jiao, L.; Li, K.; Yan, Y. Preparation of biodiesel with liquid synergetic lipases from rapeseed oil deodorizer distillate. Appl. Biochem. Biotechnol. 2017, 183, 778-791. [CrossRef]

218. Rodrigues, J.; Canet, A.; Rivera, I.; Osório, N.M.; Sandoval, G.; Valero, F.; Ferreira-Dias, S. Biodiesel production from crude Jatropha oil catalyzed by non-commercial immobilized heterologous Rhizopus oryzae and Carica papaya lipases. Bioresour. Technol. 2016, 213, 88-95. [CrossRef]

219. Mukhtar, H.; Khursheed, S.; Ikram-ul-Haq; Mumtaz, M.W.; Rashid, U.; Al-Resayes, S.I. Optimization of lipase biosynthesis from Rhizopus oryzae for biodiesel production using multiple oils. Chem. Eng. Technol. 2016, 39, 1-10. [CrossRef]

220. Zhou, G.-x.; Chen, G.-y.; Yan, B. bei Two-step biocatalytic process using lipase and whole cell catalysts for biodiesel production from unrefined jatropha oil. Biotechnol. Lett. 2015, 37, 1959-1963. [CrossRef]

221. Sattari, S.; Vahabzadeh, F.; Aghtaei, H.K. Performance of loofa-immobilized Rhizopus oryzae in the enzymatic production of biodiesel with use of oleic acid in n-hexane medium. Brazilian J. Chem. Eng. 2015, 32, 367-376. [CrossRef]

222. Ramachandran, P.; Narayanan, G.K.; Gandhi, S.; Sethuraman, S.; Krishnan, U.M. Rhizopus oryzae lipase immobilized on hierarchical mesoporous silica supports for transesterification of rice bran oil. Appl. Biochem. Biotechnol. 2015, 175, 2332-2346. [CrossRef]

223. Zarei, A.; Amin, N.A.S.; Talebian-Kiakalaieh, A.; Zain, N.A.M. Immobilized lipase-catalyzed transesterification of Jatropha curcas oil: Optimization and modeling. J. Taiwan Inst. Chem. Eng. 2014, 45, 444-451. [CrossRef]

224. Canet, A.; Dolors Benaiges, M.; Valero, F. Biodiesel synthesis in a solvent-free system by recombinant Rhizopus oryzae lipase. Study of the catalytic reaction progress. J. Am. Oil Chem. Soc. 2014, 91, 1499-1506. [CrossRef]

225. Andrade, G.S.S.; Freitas, L.; Oliveira, P.C.; De Castro, H.F. Screening, immobilization and utilization of whole cell biocatalysts to mediate the ethanolysis of babassu oil. J. Mol. Catal. B Enzym. 2012, 84, 183-188. [CrossRef]

226. Deshmukh, S.; Kumar, R.; Bala, K. Microalgae biodiesel: A review on oil extraction, fatty acid composition, properties and effect on engine performance and emissions. Fuel Process. Technol. 2019, 191, 232-247. [CrossRef]

227. Yin, Z.; Zhu, L.; Li, S.; Hu, T.; Chu, R.; Mo, F.; Hu, D.; Liu, C.; Li, B. A comprehensive review on cultivation and harvesting of microalgae for biodiesel production: Environmental pollution control and future directions. Bioresour. Technol. 2020, 301, 122804-122823. [CrossRef]

228. Lisboa, P.; Rodrigues, A.R.; Martín, J.L.; Simões, P.; Barreiros, S.; Paiva, A. Economic analysis of a plant for biodiesel production from waste cooking oil via enzymatic transesterification using supercritical carbon dioxide. J. Supercrit. Fluids 2014, 85, 31-40. [CrossRef]

229. Tsoutsos, T.; Tournaki, S.; Gkouskos, Z.; Paraíba, O.; Giglio, F.; García, P.Q.; Braga, J.; Adrianos, H.; Filice, M. Quality Characteristics of biodiesel produced from used cooking oil in Southern Europe. ChemEngineering 2019, 3, 19. [CrossRef]

230. Yaakob, Z.; Mohammad, M.; Alherbawi, M.; Alam, Z.; Sopian, K. Overview of the production of biodiesel from waste cooking oil. Renew. Sustain. Energy Rev. 2013, 18, 184-193. [CrossRef]

231. Mandolesi De Araújo, C.D.; De Andrade, C.C.; De Souza E Silva, E.; Dupas, F.A. Biodiesel production from used cooking oil: A review. Renew. Sustain. Energy Rev. 2013, 27, 445-452. [CrossRef] 
232. Zhang, Y.; Dubé, M.A.; McLean, D.D.; Kates, M. Biodiesel production from waste cooking oil: Economic assessment and sensitivity analysis. Bioresour. Technol. 2003, 90, 229-240. [CrossRef]

233. Wahab, R.A.; Elias, N.; Abdullah, F.; Ghoshal, S.K. On the taught new tricks of enzymes immobilization: An all-inclusive overview. React. Funct. Polym. 2020, 152, 104613. [CrossRef]

234. Sheldon, R.A.; Woodley, J.M. Role of Biocatalysis in Sustainable Chemistry. Chem. Rev. 2018, 118, 801-838. [CrossRef] [PubMed]

235. Fukuda, H.; Hama, S.; Tamalampudi, S.; Noda, H. Whole-cell biocatalysts for biodiesel fuel production. Trends Biotechnol. 2008, 26, 668-673. [CrossRef] [PubMed]

236. Fernandez-Lafuente, R.; Armisén, P.; Sabuquillo, P.; Fernández-Lorente, G.; Guisán, J.M. Immobilization of lipases by selective adsorption on hydrophobic supports. Chem. Phys. Lipids 1998, 93, 185-197. [CrossRef]

237. Fernandez-Lorente, G.; Rocha-Martín, J.; Guisan, J.M. Immobilization of Lipases by Adsorption on Hydrophobic Supports: Modulation of Enzyme Properties in Biotransformations in Anhydrous Media. Methods Mol. Biol. 2020, 21000, 143-158.

238. Wang, Y.D.; Shen, X.Y.; Li, Z.L.; Li, X.; Wang, F.; Nie, X.A.; Jiang, J.C. Immobilized recombinant Rhizopus oryzae lipase for the production of biodiesel in solvent free system. J. Mol. Catal. B Enzym. 2010, 67, 45-51. [CrossRef]

239. Tan, T.; Lu, J.; Nie, K.; Deng, L.; Wang, F. Biodiesel production with immobilized lipase: A review. Biotechnol. Adv. 2010, 28, 628-634. [CrossRef]

240. Balasubramaniam, B.; Sudalaiyadum Perumal, A.; Jayaraman, J.; Mani, J.; Ramanujam, P. Comparative analysis for the production of fatty acid alkyl esterase using whole cell biocatalyst and purified enzyme from Rhizopus oryzae on waste cooking oil (sunflower oil). Waste Manag. 2012, 32, 1539-1547. [CrossRef]

241. Zhao, X.; Qi, F.; Yuan, C.; Du, W.; Liu, D. Lipase-catalyzed process for biodiesel production: Enzyme immobilization, process simulation and optimization. Renew. Sustain. Energy Rev. 2015, 44, 182-197. [CrossRef]

242. Mendes, A.A.; Freitas, L.; De Carvalho, A.K.F.; De Oliveira, P.C.; De Castro, H.F. Immobilization of a commercial lipase from Penicillium camembertii (Lipase G) by different strategies. Enzyme Res. 2011, 2011. [CrossRef]

243. Illanes, A. Enzyme biocatalysis: Principles and applications. In Enzyme Biocatalysis: Principles and Applications; Springer: Valparaíso, Chile, 2008; pp. 172-173. ISBN 9781402083600.

244. Norjannah, B.; Ong, H.C.; Masjuki, H.H.; Juan, J.C.; Chong, W.T. Enzymatic transesterification for biodiesel production: A comprehensive review. RSC Adv. 2016, 6, 60034-60055. [CrossRef]

245. Lotti, M.; Pleiss, J.; Valero, F.; Ferrer, P. Effects of methanol on lipases: Molecular, kinetic and process issues in the production of biodiesel. Biotechnol. J. 2015, 10, 22-30. [CrossRef] [PubMed]

246. Ferreira-Dias, S.; Sandoval, G.; Plou, F.; Valero, F. The potential use of lipases in the production of fatty acid derivatives for the food and nutraceutical industries. Electron. J. Biotechnol. 2013, 16, 1-38.

247. Guo, Y.; Cai, Z.; Xie, Y.; Ma, A.; Zhang, H.; Rao, P.; Wang, Q. Synthesis, physicochemical properties, and health aspects of structured lipids: A review. Compr. Rev. Food Sci. Food Saf. 2020, 19, 759-800. [CrossRef]

248. Smith, R.E.; Finley, J.W.; Leveille, G.A. Overview of SALATRIM, a Family of Low-Calorie Fats. J. Agric. Food Chem. 1994, 42, 432-434. [CrossRef]

249. Osborn, H.T.; Akoh, C.C. Structured lipids-novel fats with medical, nutraceutical, and food applications. Compr. Rev. Food Sci. Food Saf. 2002, 1, 110-120. [CrossRef]

250. López-López, A.; Castellote-Bargalló, A.I.; Campoy-Folgoso, C.; Rivero-Urgel, M.; Tormo-Carnicé, R.; Infante-Pina, D.; López-Sabater, M.C. The influence of dietary palmitic acid triacylglyceride position on the fatty acid, calcium and magnesium contents of at term newborn faeces. Early Hum. Dev. 2001, 65, S83-S94. [CrossRef]

251. Şahín, N.; Akoh, C.C.; Karaalí, A. Human milk fat substitutes containing omega-3 fatty acids. J. Agric. Food Chem. 2006, 54, 3717-3722. [CrossRef]

252. Biswas, N.; Cheow, Y.L.; Tan, C.P.; Siow, L.F. Physicochemical Properties of Enzymatically Produced Palm-Oil-Based Cocoa Butter Substitute (CBS) With Cocoa Butter Mixture. Eur. J. Lipid Sci. Technol. 2018, 120, 1700205. [CrossRef]

253. Yamoneka, J.; Malumba, P.; Lognay, G.; Béra, F.; Blecker, C.; Danthine, S. Enzymatic Inter-Esterification of Binary Blends Containing Irvingia gabonensis Seed Fat to Produce Cocoa Butter Substitute. Eur. J. Lipid Sci. Technol. 2018, 120, 1700423. [CrossRef] 
254. Lakum, R.; Sonwai, S. Production of trans-free margarine fat by enzymatic interesterification of soybean oil, palm stearin and coconut stearin blend. Int. J. Food Sci. Technol. 2018, 53, 2761-2769. [CrossRef]

255. Li, Y.; Zhao, J.; Xie, X.; Zhang, Z.; Zhang, N.; Wang, Y. A low trans margarine fat analog to beef tallow for healthier formulations: Optimization of enzymatic interesterification using soybean oil and fully hydrogenated palm oil. Food Chem. 2018, 255, 405-413. [CrossRef] [PubMed]

256. Kawashima, A.; Shimada, Y.; Yamamoto, M.; Sugihara, A.; Nagao, T.; Komemushi, S.; Tominaga, Y. Enzymatic synthesis of high-purity structured lipids with caprylic acid at 1, 3-positions and polyunsaturated fatty acid at 2-position. JAOCS, J. Am. Oil Chem. Soc. 2001, 78, 611-616. [CrossRef]

257. Lo, S.K.; Tan, C.P.; Long, K.; Yusoff, M.S.A.; Lai, O.M. Diacylglycerol oil-properties, processes and products: A review. Food Bioprocess Technol. 2008, 1, 223-233. [CrossRef]

258. Iwasaki, Y.; Yamane, T. Enzymatic synthesis of structured lipids. Adv. Biochem. Eng. Biotechnol. 2004, 10, 129-140.

259. Kim, B.H.; Akoh, C.C. Recent Research Trends on the Enzymatic Synthesis of Structured Lipids. J. Food Sci. 2015, 80, C1713-C1724. [CrossRef]

260. Utama, Q.D.; Sitanggang, A.B.; Adawiyah, D.R.; Hariyadi, P. Lipase-catalyzed interesterification for the synthesis of medium-long-medium (MLM) structured lipids - A review. Food Technol. Biotechnol. 2019, 57, 305-318. [CrossRef]

261. Nunes, P.A.; Pires-Cabral, P.; Guillén, M.; Valero, F.; Luna, D.; Ferreira-Dias, S. Production of MLM-type structured lipids catalyzed by immobilized heterologous Rhizopus oryzae lipase. JAOCS, J. Am. Oil Chem. Soc. 2011, 64, 57-68. [CrossRef]

262. Mota, D.A.; Rajan, D.; Heinzl, G.C.; Osório, N.M.; Gominho, J.; Krause, L.C.; Soares, C.M.F.; Nampoothiri, K.M.; Sukumaran, R.K.; Ferreira-Dias, S. Production of low-calorie structured lipids from spent coffee grounds or olive pomace crude oils catalyzed by immobilized lipase in magnetic nanoparticles. Bioresour. Technol. 2020, 307, 123223-123232. [CrossRef]

263. Costa, C.M.; Osório, N.M.; Canet, A.; Rivera, I.; Sandoval, G.; Valero, F.; Ferreira-Dias, S. Production of MLM Type Structured Lipids From Grapeseed Oil Catalyzed by Non-Commercial Lipases. Eur. J. Lipid Sci. Technol. 2018, 120, 1700320-1700328. [CrossRef]

264. Nagao, T.; Kawashima, A.; Sumida, M.; Watanabe, Y.; Akimoto, K.; Fukami, H.; Sugihara, A.; Shimada, Y. Production of Structured TAG Rich in 1,3-Capryloyl-2-arachidonoyl Glycerol from Mortierella Single-Cell Oil. JAOCS, J. Am. Oil Chem. Soc. 2003, 80, 867-872. [CrossRef]

265. Nunes, P.A.; Pires-Cabral, P.; Guillén, M.; Valero, F.; Ferreira-Dias, S. Batch operational stability of immobilized heterologous Rhizopus oryzae lipase during acidolysis of virgin olive oil with medium-chain fatty acids. Biochem. Eng. J. 2012, 67, 265-268. [CrossRef]

266. Nunes, P.A.; Pires-Cabral, P.; Guillén, M.; Valero, F.; Ferreira-Dias, S. Optimized production of MLM triacylglycerols catalyzed by immobilized heterologous Rhizopus oryzae lipase. JAOCS, J. Am. Oil Chem. Soc. 2012, 89, 1287-1295. [CrossRef]

267. Balieiro, A.L.; Osório, N.M.; Lima, Á.S.; Soares, C.M.F.; Valero, F.; Ferreira-Dias, S. Production of dietetic triacylglycerols from olive oil catalyzed by immobilized heterologous Rhizopus oryzae lipase. Chem. Eng. Trans. 2018, 64, 385-390.

268. Esteban, L.; Jiménez, M.J.; Hita, E.; González, P.A.; Martín, L.; Robles, A. Production of structured triacylglycerols rich in palmitic acid at sn-2 position and oleic acid at sn-1,3 positions as human milk fat substitutes by enzymatic acidolysis. Biochem. Eng. J. 2011, 54, 62-69. [CrossRef]

269. Simões, T.; Valero, F.; Tecelão, C.; Ferreira-Dias, S. Production of human milk fat substitutes catalyzed by a heterologous Rhizopus oryzae lipase and commercial lipases. JAOCS, J. Am. Oil Chem. Soc. 2014, 91, 411-419. [CrossRef]

270. Faustino, A.R.; Osório, N.M.; Tecelão, C.; Canet, A.; Valero, F.; Ferreira-Dias, S. Camelina oil as a source of polyunsaturated fatty acids for the production of human milk fat substitutes catalyzed by a heterologous Rhizopus oryzae lipase. Eur. J. Lipid Sci. Technol. 2016, 118, 532-544. [CrossRef]

271. del Muñío, M.M.; Robles, A.; Esteban, L.; González, P.A.; Molina, E. Synthesis of structured lipids by two enzymatic steps: Ethanolysis of fish oils and esterification of 2-monoacylglycerols. Process Biochem. 2009, 44, 723-730. 
272. Hita, E.; Robles, A.; Camacho, B.; Ramírez, A.; Esteban, L.; Jiménez, M.J.; Muñío, M.M.; González, P.A.; Molina, E. Production of structured triacylglycerols (STAG) rich in docosahexaenoic acid (DHA) in position 2 by acidolysis of tuna oil catalyzed by lipases. Process Biochem. 2007, 42, 415-422. [CrossRef]

273. Rodríguez, A.; Esteban, L.; Martín, L.; Jiménez, M.J.; Hita, E.; Castillo, B.; González, P.A.; Robles, A. Synthesis of 2-monoacylglycerols and structured triacylglycerols rich in polyunsaturated fatty acids by enzyme catalyzed reactions. Enzyme Microb. Technol. 2012, 51, 148-155. [CrossRef]

274. Zhou, D.; Xu, X.; Mu, H.; HØY, C.E.; Adler-Nissen, J. Lipase-catalyzed production of structured lipids via acidolysis of fish oil with caprylic acid. J. Food Lipids 2000, 7, 263-274. [CrossRef]

275. Paula, A. V.; Nunes, G.F.M.; De Castro, H.F.; Santos, J.C. Synthesis of structured lipids by enzymatic interesterification of milkfat and soybean oil in a basket-type stirred tank reactor. Ind. Eng. Chem. Res. 2015, 54, 1731-1737. [CrossRef]

276. Ray, J.; Nagy, Z.K.; Smith, K.W.; Bhaggan, K.; Stapley, A.G.F. Kinetic study of the acidolysis of high oleic sunflower oil with stearic-palmitic acid mixtures catalysed by immobilised Rhizopus oryzae lipase. Biochem. Eng. J. 2013, 73, 17-28. [CrossRef]

277. Yang, T.; Fruekilde, M.B.; Xu, X. Suppression of acyl migration in enzymatic production of structured lipids through temperature programming. Food Chem. 2005, 92, 101-107. [CrossRef]

278. SÁ, A.G.A.; Meneses, A.C. de; Araújo, P.H.H. de; Oliveira, D. de A review on enzymatic synthesis of aromatic esters used as flavor ingredients for food, cosmetics and pharmaceuticals industries. Trends Food Sci. Technol. 2017, 69, 95-105. [CrossRef]

279. Gao, W.; Wu, K.; Chen, L.; Fan, H.; Zhao, Z.; Gao, B.; Wang, H.; Wei, D. A novel esterase from a marine mud metagenomic library for biocatalytic synthesis of short-chain flavor esters. Microb. Cell Fact. 2016, 15, 41-53. [CrossRef]

280. Huang, S.-M.; Huang, H.-Y.; Chen, Y.-M.; Kuo, C.-H.; Shieh, C.-J. Continuous Production of 2-Phenylethyl Acetate in a Solvent-Free System Using a Packed-Bed Reactor with Novozym®435. Catalysts 2020, 10, 714-727. [CrossRef]

281. Bayout, I.; Bouzemi, N.; Guo, N.; Mao, X.; Serra, S.; Riva, S.; Secundo, F. Natural flavor ester synthesis catalyzed by lipases. Flavour Fragr. J. 2020, 35, 209-218. [CrossRef]

282. Asmat, S.; Husain, Q. A robust nanobiocatalyst based on high performance lipase immobilized to novel synthesised poly(o-toluidine) functionalized magnetic nanocomposite: Sterling stability and application. Mater. Sci. Eng. C 2019, 99, 25-36. [CrossRef]

283. Asmat, S.; Anwer, A.H.; Husain, Q. Immobilization of lipase onto novel constructed polydopamine grafted multiwalled carbon nanotube impregnated with magnetic cobalt and its application in synthesis of fruit flavours. Int. J. Biol. Macromol. 2019, 140, 484-495. [CrossRef]

284. Moreira, W.C.; Elias, A.L.P.; Osório, W.R.; Padilha, G.S. Alternative method to improve the ethyl valerate yield using an immobilised Burkholderia cepacia lipase. J. Microencapsul. 2019, 36, 327-337. [CrossRef]

285. Rodriguez-Nogales, J.M.; Roura, E.; Contreras, E. Biosynthesis of ethyl butyrate using immobilized lipase: A statistical approach. Process Biochem. 2005, 40, 63-68. [CrossRef]

286. Guillén, M.; Benaiges, M.D.; Valero, F. Biosynthesis of ethyl butyrate by immobilized recombinant Rhizopus oryzae lipase expressed in Pichia pastoris. Biochem. Eng. J. 2012, 65, 1-9. [CrossRef]

287. Guillén, M.; Benaiges, M.D.; Valero, F. Improved ethyl butyrate synthesis catalyzed by an immobilized recombinant Rhizopus oryzae lipase: A comprehensive statistical study by production, reaction rate and yield analysis. J. Mol. Catal. B Enzym. 2016, 133, S371-S376. [CrossRef]

288. Grosso, C.; Ferreira-Dias, S.; Pires-Cabral, P. Modelling and optimization of ethyl butyrate production catalysed by Rhizopus oryzae lipase. J. Food Eng. 2013, 115, 475-480. [CrossRef]

289. Ben Salah, R.; Ghamghui, H.; Miled, N.; Mejdoub, H.; Gargouri, Y. Production of butyl acetate ester by lipase from novel strain of Rhizopus oryzae. J. Biosci. Bioeng. 2007, 103, 368-372. [CrossRef]

290. Kumari, A.; Mahapatra, P.; Garlapati, V.K.; Banerjee, R.; Dasgupta, S. Lipase mediated isoamyl acetate synthesis in solvent-free system using vinyl acetate as acyl donor. Food Technol. Biotechnol. 2009, 47, 13-18.

291. Ghamgui, H.; Karra-Chaâbouni, M.; Bezzine, S.; Miled, N.; Gargouri, Y. Production of isoamyl acetate with immobilized Staphylococcus simulans lipase in a solvent-free system. Enzyme Microb. Technol. 2006, 38, 788-794. [CrossRef]

292. Garlapati, V.K.; Banerjee, R. Solvent-free synthesis of flavour esters through immobilized lipase mediated transesterification. Enzyme Res. 2013, 2013. [CrossRef] 
293. Dhake, K.P.; Deshmukh, K.M.; Patil, Y.P.; Singhal, R.S.; Bhanage, B.M. Improved activity and stability of Rhizopus oryzae lipase via immobilization for citronellol ester synthesis in supercritical carbon dioxide. J. Biotechnol. 2011, 156, 46-51. [CrossRef]

294. Rios, N.S.; Pinheiro, B.B.; Pinheiro, M.P.; Bezerra, R.M.; dos Santos, J.C.S.; Barros Gonçalves, L.R. Biotechnological potential of lipases from Pseudomonas: Sources, properties and applications. Process Biochem. 2018, 75, 99-120. [CrossRef]

295. Kirchner, G.; Scollar, M.P.; Klibanov, A.M. Resolution of Racemic Mixtures via Lipase Catalysis in Organic Solvents. J. Am. Chem. Soc. 1985, 107, 7072-7076. [CrossRef]

296. Palomo, J.M.; Segura, R.L.; Fernandez-Lorente, G.; Guisán, J.M.; Fernandez-Lafuente, R. Enzymatic resolution of $( \pm)$-glycidyl butyrate in aqueous media. Strong modulation of the properties of the lipase from Rhizopus oryzae via immobilization techniques. Tetrahedron Asymmetry 2004, 15, 1157-1161. [CrossRef]

297. Songür, R.; Lurçi, B.; Bayraktar, E.; Mehmetoğlu, \&\#xDC;.; Demir, A.S. Enantioselective production of benzoin from benzoin acetate via kinetic resolution and deracemization using Rhizopus oryzae. Artif. Cells Blood Substit. Biotechnol. 2011, 39, 162-168.

298. Cabrera, Z.; Palomo, J.M. Enantioselective desymmetrization of prochiral diesters catalyzed by immobilized Rhizopus oryzae lipase. Tetrahedron Asymmetry 2011, 22, 2080-2084. [CrossRef]

299. Yousefi, M.; Mohammadi, M.; Habibi, Z. Enantioselective resolution of racemic ibuprofen esters using different lipases immobilized on octyl sepharose. J. Mol. Catal. B Enzym. 2014, 104, 87-94. [CrossRef]

300. Matsumoto, T.; Ito, M.; Fukuda, H.; Kondo, A. Enantioselective transesterification using lipase-displaying yeast whole-cell biocatalyst. Appl. Microbiol. Biotechnol. 2004, 64, 481-485. [CrossRef]

301. Nakamura, Y.; Matsumoto, T.; Nomoto, F.; Ueda, M.; Fukuda, H.; Kondo, A. Enhancement of activity of lipase-displaying yeast cells and their application to optical resolution of (R,S)-1-benzyloxy-3-chloro-2-propyl monosuccinate. Biotechnol. Prog. 2006, 22, 998-1002. [CrossRef]

Publisher's Note: MDPI stays neutral with regard to jurisdictional claims in published maps and institutional affiliations. 